\title{
Fenestelloid clades of the Cucurbitariaceae
}

\author{
W.M. Jaklitsch ${ }^{1,2}$, H. Voglmayr ${ }^{1,2}$
}

\section{Key words}

\section{Cucurbitaria}

Dothideomycetes

multigene phylogenetic analysis new taxa

Phoma

Pleosporales

Pyrenochaeta

\begin{abstract}
Fresh collections and their ascospore and conidial isolates backed up by type studies and molecular phylogenetic analyses of a multigene matrix of partial nuSSU-, complete ITS, partial LSU rDNA, rpb2, tef1 and tub2 sequences were used to evaluate the boundaries and species composition of Fenestella and related genera of the Cucurbitariaceae. Eight species, of which five are new, are recognised in Fenestella s.str., 13 in Parafenestella with eight new species and two in the new genus Synfenestella with one new species. Cucurbitaria crataegi is combined in Fenestella, C. sorbi in Synfenestella, Fenestella faberi and Thyridium salicis in Parafenestella. Cucurbitaria subcaespitosa is distinct from C. sorbi and combined in Neocucurbitaria. Fenestella minor is a synonym of Valsa tetratrupha, which is combined in Parafenestella. Cucurbitaria marchica is synonymous with Parafenestella salicis, Fenestella bavarica with S. sorbi, F. macrospora with F. media, and P. mackenziei is synonymous with P. faberi, and the latter is lectotypified. Cucurbitaria sorbi, C. subcaespitosa and Fenestella macrospora are lecto- and epitypified, Cucurbitaria crataegi, Fenestella media, F. minor and Valsa tetratrupha are epitypified in order to stabilise the names in their phylogenetic positions. A neotype is proposed for Thyridium salicis. A determinative key to species is given. Asexual morphs of fenestelloid fungi are phoma-like and do not differ from those of other representatives of the Cucurbitariaceae. The phylogenetic structure of the fenestelloid clades is complex and can only be resolved at the species level by protein-coding genes, such as $r p b 2$, tef1 and tub2. All fungal species studied here occur, as far as has been possible to determine, on members of Diaporthales, most frequently on asexual and sexual morphs of Cytospora.
\end{abstract}

Article info Received: 10 December 2018; Accepted: 13 February 2019; Published: 27 May 2019

\section{INTRODUCTION}

Phylogenetic assignment of non-lichenised pyrenocarpous ascomycetes forming brown muriform ascospores is a complex and ongoing task. While fungi with such ascospores are rather rare in Sordariomycetes, e.g., Dictyoporthe s.lat. (Jaklitsch \& Barr 1997), Stegonsporium (Voglmayr \& Jaklitsch 2008, 2014) in Diaporthales, Strickeria (Xylariales; Jaklitsch et al. 2016a), Thyronectria (Hypocreales; Jaklitsch \& Voglmayr 2014, Voglmayr et al. 2016a) or Thyridium (Spatafora et al. 2006), they are common in many families of Dothideomycetes, particularly in several of the Pleosporales (Jaklitsch et al. 2016b). The Cucurbitariaceae is one of these families. In contrast to genera like, e.g., Thyronectria (Hypocreales; Jaklitsch \& Voglmayr 2014, Voglmayr et al. 2016a) or Teichospora (Pleosporales; Jaklitsch et al. 2016c), where both phragmospores and dictyospores cluster in the same genus, all sexual morphs of the Cucurbitariaceae (Pleosporales) have dictyospores (Jaklitsch et al. 2018). Other characters shared by all representatives of this family are the presence of a subiculum and phoma- or pyrenochaeta-like asexual morphs, although these characters may occur in several other families, too (Jaklitsch et al. 2018, Valenzuela-Lopez et al. 2018). Several species of Cucurbitaria with no or other asexual morphs have been recently removed to different families of Pleosporales, e.g., Coniothyriaceae (Cucurbitaria varians; Crous \& Groenewald 2017), Camarosporidiella-

\footnotetext{
Institute of Forest Entomology, Forest Pathology and Forest Protection, Department of Forest and Soil Sciences, BOKU-University of Natural Resources and Life Sciences, Franz Schwackhöfer Haus, Peter-JordanStraße 82/l, 1190 Vienna, Austria; corresponding author e-mail: walter.jaklitsch@univie.ac.at.

2 Division of Systematic and Evolutionary Botany, Department of Botany and Biodiversity Research, University of Vienna, Rennweg 14, 1030 Wien, Austria.
}

ceae (most cucurbitaria-like species on fabaceous hosts; Wanasinghe et al. 2017a), Melanommataceae (e.g., C. obducens; Jaklitsch \& Voglmayr 2017) or Nectriaceae (C. bicolor in Thyronectria; Checa et al. 2015). In a foregoing publication, Jaklitsch et al. (2018) redefined the scope of the Cucurbitariaceae and included the generic type of Fenestella, F. fenestrata, by redescription, illustration, lecto- and epitypification and DNA data. Other fenestella-like species were included in that work as the new genera Cucitella, Parafenestella, Protofenestella and Seltsamia.

After the original publication of Fenestella by Tulasne \& Tulasne (1863), who recognised three species in the genus including $F$. princeps, a synonym of $F$. fenestrata (see Jaklitsch et al. 2018), 52 additional species names were created in the genus. Eleven names including Fenestella bipapillata (Jaklitsch \& Barr 1997) and Fenestella frit (see Jaklitsch et al. 2018) have been removed to other genera or they, among others, are not interpretable, because no type material exists (for more data see notes to species and Discussion). Barr (1990) recognised eight species in Fenestella occurring in North America, which she keyed out and described morphologically. She also gave a detailed diagnosis of the genus Fenestella recognising its fungicolous habit. However, she subsumed American fungi under European Fenestella names without having seen type material of most of them. As a result, several of her taxonomic interpretations and conclusions are either erratic or too broad. A definition of what fenestelloid fungi are is difficult, particularly when compared to other members of the Cucurbitariaceae. The main character apart from a more marked tendency to form valsoid groups or pseudostromatic pustules, are the ascospores, whose septa are variable in number and often difficult to count due to incompleteness, dense insertion and apparent oblique or shifted superposition in sectional view. This character is

○) 2019-2020 Naturalis Biodiversity Center \& Westerdijk Fungal Biodiversity Institute

You are free to share - to copy, distribute and transmit the work, under the following conditions:

$\begin{array}{ll}\text { Attribution: } & \text { You must attribute the work in the manner specified by the author or licensor (but not in any way that suggests that they endorse you or your use of the work) } \\ \text { Non-commercial: } & \text { You may not use this work for commercial purposes. }\end{array}$

Non-commercia:

No derivative works: You may not alter, transform, or build upon this work.

For any reuse or distribution, you must make clear to others the license terms of this work, which can be found at http://creativecommons.org/licenses/by-nc-nd/3.0/legalcode. Any of the above conditions can be waived if you get permission from the copyright holder. Nothing in this license impairs or restricts the author's moral rights. 


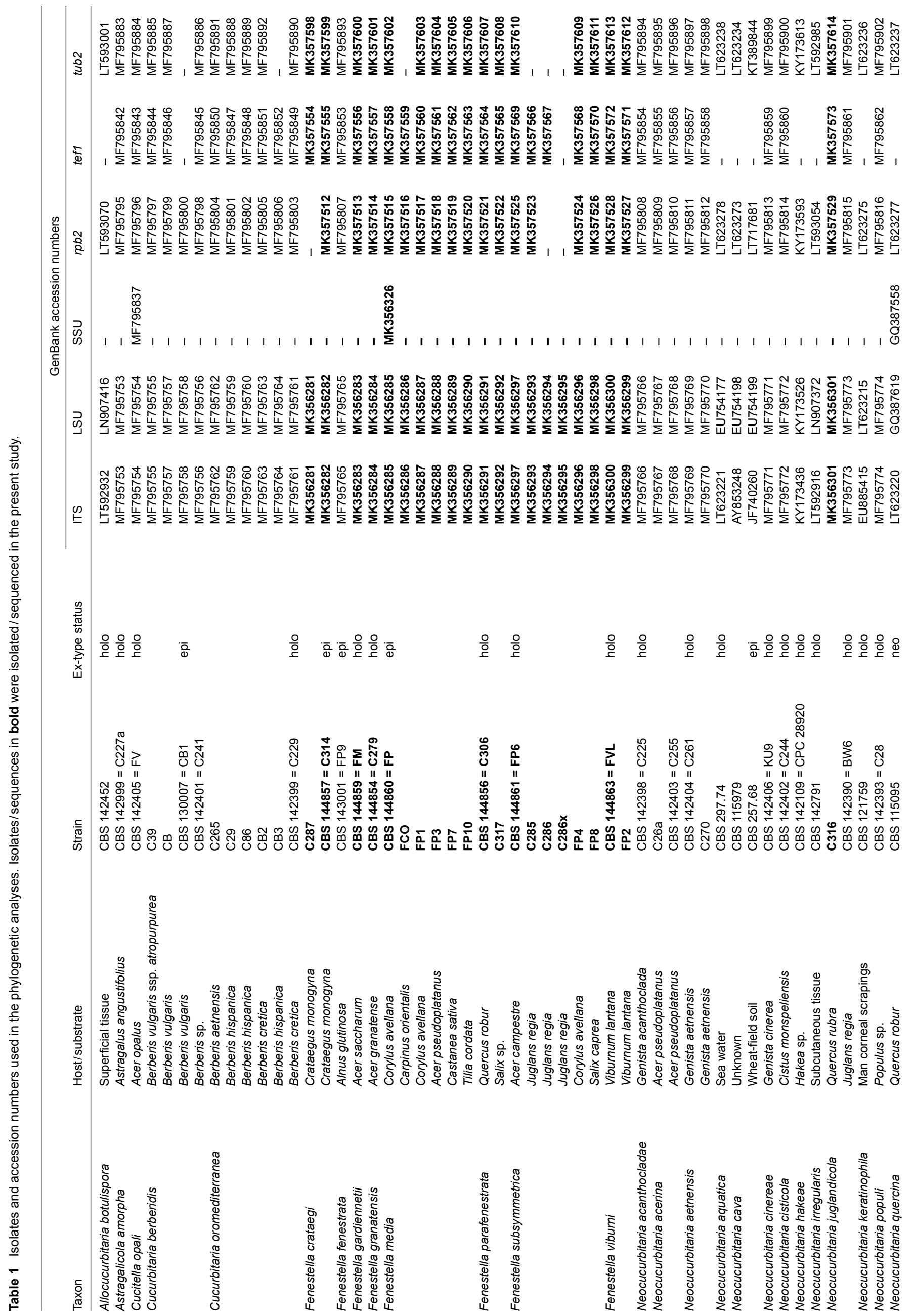




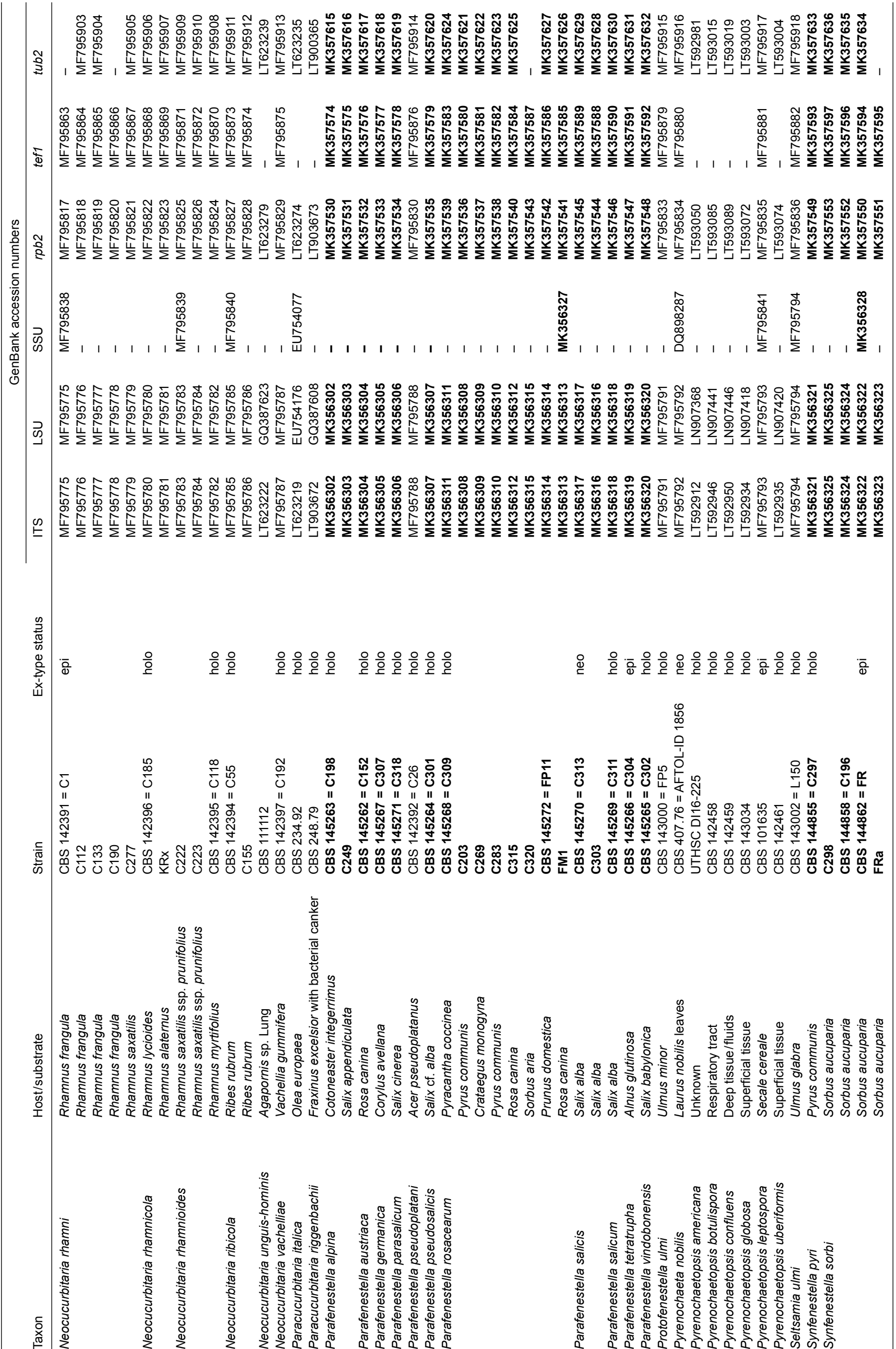


shared with the morphologically rather pleomassariaceous genus Seltsamia (Jaklitsch et al. 2018), whose ascospores have an indefinitely swelling, bipartite sheath. A similar situation is found in Fenestella as shown below for $F$. granatensis, where the ascospore sheath swells however in a limited manner. Other unrelated, non-lichenised pyrenocarpous fungi on or in wood and bark having ascospores with many transverse and longitudinal eusepta in more or less cylindrical, fissitunicate asci are Aigialus, differing from fenestelloid fungi, e.g., in different ecology, as ascomata are immersed in submerged wood of mangroves in marine environments (Kohlmeyer \& Schatz 1985), Decaisnella and Karstenula in the very wide concept of Barr (1990), which, e.g., lack a subiculum and are not associated with Diaporthales, or Ostreichnion, which produces conchate, superficial ascomata on wood (Boehm et al. 2009).

Here we take a detailed look into the taxonomy and phylogenetic structure of fenestelloid fungi described from Europe on woody hosts, from which fresh material was available for study. These fungi include several species originally described in Fenestella, Cucurbitaria or Thyridium, and cluster in three clades representing the three genera Fenestella, Parafenestella and Synfenestella.

\section{MATERIALS AND METHODS}

\section{Isolates and specimens}

All isolates used in this study originated from ascospores or conidia (where noted) of fresh specimens. Numbers of strains including NCBI GenBank accession numbers of gene sequences used to compute the phylogenetic trees are listed in Table 1. Strain acronyms other than those of official culture collections are used here primarily as strain identifiers throughout the work. Representative isolates have been deposited at the Westerdijk Fungal Biodiversity Centre, Utrecht, The Netherlands (CBS culture collection). Details of the specimens used for morphological investigations are listed in the Taxonomy section under the respective descriptions. Herbarium acronyms are according to Thiers (2018). Freshly collected specimens have been deposited in the Fungarium of the Department of Botany and Biodiversity Research, University of Vienna (WU).

\section{Culture preparation and phenotype analysis}

Cultures were prepared and maintained as described previously (Jaklitsch 2009) except that CMD (CMA; Sigma, St Louis, Missouri; supplemented with $2 \%(w / v) D(+)$-glucose-monohydrate) or $2 \%$ malt extract agar (MEA; $2 \% \mathrm{w} / \mathrm{v}$ malt extract, $2 \% \mathrm{w} / \mathrm{v}$ agar-agar; Merck, Darmstadt, Germany) was used as the isolation medium. Cultures used for the study of asexual morph micro-morphology were grown on CMD or $2 \%$ MEA at $22 \pm 3^{\circ} \mathrm{C}$ in darkness. Microscopic observations were made in tap water except where noted. Morphological analyses of microscopic characters were carried out as described by Jaklitsch (2009). Methods of microscopy included stereomicroscopy using a Nikon SMZ 1500 and Nomarski differential interference contrast (DIC) using the compound microscopes Nikon Eclipse E600 or Zeiss Axio Imager.A1 equipped with a Zeiss Axiocam 506 colour digital camera. Images and data were gathered using a Nikon Coolpix 4500 or a Nikon DS-U2 digital camera and measured by using the NIS-Elements D v. 3.0 or 3.22 .15 or Zeiss ZEN Blue Edition software packages. Some images obtained by using the Nikon interference contrast may be slightly too dark. For certain images of ascomata the stacking software Zerene Stacker v. 1.04 (Zerene Systems LLC, Richland, WA, USA) was used. Measurements are reported as maxima and minima in parentheses and the mean plus and minus the standard deviation of a number of measurements given in parentheses.

\section{DNA extraction and sequencing methods}

The extraction of genomic DNA was performed as reported previously (Voglmayr \& Jaklitsch 2011, Jaklitsch et al. 2012) using the DNeasy Plant Mini Kit (QIAgen GmbH, Hilden, Germany). The following loci were amplified and sequenced: the terminal 3 ' end of the small subunit nuclear ribosomal DNA (nSSU rDNA), the complete internally transcribed spacer region (ITS1-5.8SITS2) and a c. $900 \mathrm{bp}$ fragment of the large subunit nuclear ribosomal DNA (nLSU rDNA), amplified and sequenced as a single fragment with primers V9G (De Hoog \& Gerrits van den Ende 1998) and LR5 (Vilgalys \& Hester 1990); a c. 1.0-1.4 $\mathrm{kb}$ fragment at the 5 ' end of the nSSU rDNA with primers SL1 (Landvik et al. 1997) and NSSU1088 (Kauff \& Lutzoni 2002); a c. $1.2 \mathrm{~kb}$ fragment of the RNA polymerase II subunit 2 (rpb2) gene with primers fRPB2-5f and fRPB2-7cr (Liu et al. 1999) or dRPB2-5f and dRPB2-7r (Voglmayr et al. 2016a); a c. 1.3-1.5 $\mathrm{kb}$ fragment of the translation elongation factor 1-alpha (tef1) gene with primers EF1-728F (Carbone \& Kohn 1999) and TEF1LLErev (Jaklitsch et al. 2005) or EF1-2218R (Rehner \& Buckley 2005); and a c. $0.7 \mathrm{~kb}$ fragment of the beta tubulin (tub2) gene with primers T1 (O'Donnell \& Cigelnik 1997) or T1HV (Voglmayr et al. 2016b) and BtHV2r (Voglmayr et al. 2016b, 2017). PCR products were purified using an enzymatic PCR clean-up (Werle et al. 1994) as described in Voglmayr \& Jaklitsch (2008). DNA was cycle-sequenced using the $A B I$ PRISM Big Dye Terminator Cycle Sequencing Ready Reaction Kit v. 3.1 (Applied Biosystems, Warrington, UK) with the same primers as in PCR; in addition, primers ITS4 (White et al. 1990), LR2R-A (Voglmayr et al. 2012) and LR3 (Vilgalys \& Hester 1990) were used for the ITS-LSU region. In some cases the tef1 was cycle-sequenced with internal primers TEF1_INTF (forward; Jaklitsch 2009) and TEF1_INT2 (reverse; Voglmayr \& Jaklitsch 2017). Sequencing was performed on an automated DNA sequencer (3730xl Genetic Analyzer, Applied Biosystems).

\section{Analysis of sequence data}

For the phylogenetic analyses, a combined matrix of nSSU-ITSLSU rDNA, rpb2, tef1 and tub2 sequences was produced. The newly generated sequences were complemented with GenBank sequences of Cucurbitariaceae from Jaklitsch et al. (2018), and sequences of six taxa of Pyrenochaetopsis (Pyrenochaetopsidaceae) were added as outgroup according the results of the phylogenetic analyses of Jaklitsch et al. (2018). All alignments were produced with the server version of MAFFT (www.ebi. ac.uk/Tools/mafft), checked and refined using BioEdit v. 7.2.6 (Hall 1999). Large insertions sometimes present in the SSU and at the terminal 3' end of the SSU of the partial SSU-ITS-LSU fragment were removed from the alignments.

The combined matrix contained 5707 nucleotide characters, represented by 1688 from the partial SSU-ITS-LSU, 999 from the SSU, 1067 from rpb2, 1258 from tef1 and 695 from tub2.

Maximum parsimony (MP) analysis was performed using a parsimony ratchet approach. For this, a nexus file was prepared using PRAP v. 2.0b3 (Müller 2004), implementing 1000 ratchet replicates with $25 \%$ of randomly chosen positions upweighted to 2 , which was then run with PAUP v. 4.0a164 (Swofford 2002). The resulting best trees were then loaded in PAUP and subjected to heuristic search with TBR branch swapping (MULTREES option in effect, steepest descent option not in effect). Bootstrap analysis with 1000 replicates was performed using 5 rounds of replicates of heuristic search with random addition of sequences and subsequent TBR branch swapping (MULTREES option in effect, steepest descent option not in effect) during each bootstrap replicate. In all MP analyses molecular characters were unordered and given equal weight; analyses were performed with gaps treated as missing data; the COLLAPSE 


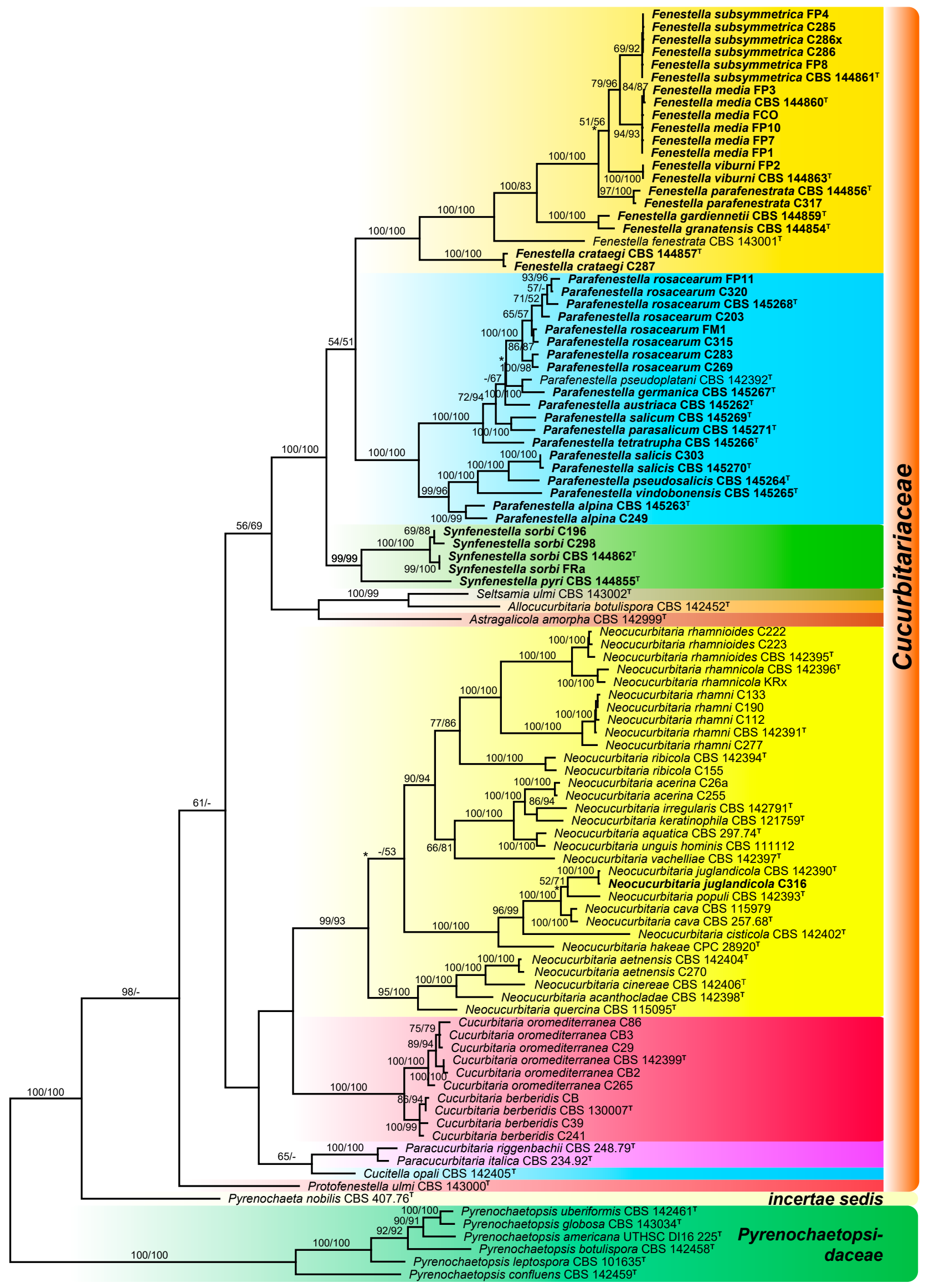

50 changes

Fig. 1 Phylogram of one of $33 \mathrm{MP}$ trees 6241 steps long $(\mathrm{Cl}=0.386, \mathrm{RI}=0.817$ ), obtained by PAUP from an analysis of the combined matrix (SSU-ITS-LSU, $r p b 2$, tef1, tub2) of Cucurbitariaceae and Pyrenochaetopsidaceae, with the latter selected as outgroup. MP and ML bootstrap support above $50 \%$ are given at the first and second position, respectively, above or below the branches. Strains formatted in bold were isolated and sequenced in the current study; ex-type strains are indicated by a superscript T. Nodes collapsed in the strict consensus of the 33 MP trees are marked by an asterisk (*). 
command was set to minbrlen. Maximum likelihood (ML) analyses were performed with RAxML (Stamatakis 2006) as implemented in raxmIGUI 1.5 (Silvestro \& Michalak 2012), using the $M L+$ rapid bootstrap setting and the GTRGAMMA substitution model with 1000 bootstrap replicates. The matrix was partitioned for the individual gene regions, and substitution model parameters were calculated separately for them. For evaluation and discussion of bootstrap support, values below $70 \%$ were considered low, between 70 and $90 \%$ medium/ moderate and above $90 \%$ high.

\section{RESULTS}

\section{Phylogenetic analyses}

Of the 5707 nucleotide characters of the combined matrix, 1266 are parsimony informative (283 of ITS-LSU, 5 of SSU, 423 of $r p b 2,302$ of tef1 and 253 of $t u b 2)$. Maximum parsimony analyses revealed 33 MP trees 6241 steps long, one of which is shown as Fig. 1. Topologies of the MP trees were identical except for one backbone node each within the Fenestella and Parafenestella clades, and two backbone nodes within the Neocucurbitaria clade (marked by asterisks in Fig. 1).

Like in the previous phylogenetic analyses of Jaklitsch et al. (2018), many of the deeper nodes within Cucurbitariaceae were unsupported or received only low support, while the genera Cucurbitaria and Neocucurbitaria were highly supported. The fenestelloid clade received maximum support and contained three highly supported subclades here recognised as three distinct genera: Fenestella, Parafenestella (both with maximum support in MP and ML analyses) and Synfenestella (99\% MP and ML bootstrap support). The sister group relationship of Fenestella and Parafenestella received only low support (54\% MP and $51 \% \mathrm{ML}$ ), while most backbone nodes within the three genera received high to maximum support (Fig. 1).

\section{Taxonomy}

Fenestella Tul. \& C. Tul., Select. Fung. Carpol. (Paris): XylarieiValsei-Spaeriei 2: 207. 1863, emend.

Type species. Fenestella fenestrata (Berk. \& Broome) J. Schröt.

Fenestella fenestrata (Berk. \& Broome) J. Schröt., in Cohn, Krypt.-FI. Schlesien (Breslau) 3.2(4): 435.1897 (1908)

Basionym. Valsa fenestrata Berk. \& Broome, Ann. Mag. Nat. Hist., ser. III 3: 366. 1859.

Synonym. Fenestella princeps Tul. \& C. Tul., Select. Fung. Carpol. (Paris) 2: 207.1863

Notes - See Jaklitsch et al. (2018) for description and typification of the genus and its type species. In that work it was stated that all materials of $F$. fenestrata available for study were more or less overmature, which made identification of the fungal host difficult. The black encasement of ascomata was interpreted as belonging to a Diaporthe sp. Considering that all other species of the genus occur on Cytospora spp. (see below), it appears probable that the stromatic encasement belonged to a Cytospora sp. having a Leucostoma sexual morph.

The second specimen given in the protologue of $F$. fenestrata was examined: England, Leicestershire, Orton Wood, on dead twigs of Quercus robur, Mar. 1859, A. Bloxam (K(M) 233193; as Valsa fenestrata). Although the plant host would suggest Fenestella parafenestrata (see below), the fungus in this specimen is morphologically indistinguishable from $F$. fenestrata: Pseudostromatic pustules are 1-4 mm diam, brown to black, outside limited by a black stromatic line, ascomata $400-770 \mu \mathrm{m}$ diam, ostiolar areas 180-420 $\mu \mathrm{m}$ diam, asci are cylindrical and ascospores (35-)43-61(-74) × (14.5-)16.5-22.5(-27) $\mu \mathrm{m}, \mathrm{l} / \mathrm{w}$ $(2-) 2.3-3.1(-3.5)(n=30)$, ellipsoid to fusoid, very dark brown, symmetric or asymmetric, with up to 16 distinct transverse and 7 longitudinal septa and up to $4 \mu \mathrm{m}$ long hyaline apiculi. See Fig. $6 \mathrm{~b} 1$ for the illustration of an ascospore.

Fenestella crataegi (Niessl) Jaklitsch \& Voglmayr, comb. nov. — MycoBank MB829741; Fig. 2

Basionym. Cucurbitaria crataegi Niessl, Verh. Naturf. Vereins Brünn 10: 199. 1872.

Holotype. CzeCH Republic, near Brno, on dry branches of Crataegus oxyacanthae (used at that time for C. monogyna), no date given, G. Niess/ (M-0281851). Epitype, here designated: AustRIA, Burgenland, Purbach, Purbacher Heide, on Cytospora sp. on a branch of Crataegus monogyna, soc. Diplodia sp., 24 Mar. 2018, H. Voglmayr (WU 36987; MBT385683; ex-epitype culture CBS $144857=$ C314).

Ascomata (330-)368-507(-540) $\mu \mathrm{m}(\mathrm{n}=12)$ diam, globose, subglobose to pyriform, immersed in groups of $0.9-2.4 \mathrm{~mm}$ diam or length containing usually less than 10 individuals or solitarily above Cytospora (Valsa) ascomata or conidiomata in a single or two vertical layers, and erumpent from bark; ascomata individually surrounded by shiny, pale to dark brown, thick-walled, 2-6.5 $\mu \mathrm{m}$ wide subicular hyphae connecting them and sometimes forming pseudostromatic structures. Ostiolar areas 90-180 $\mu \mathrm{m}$ diam, black, poorly differentiated from the venter and inconspicuous, less commonly papillate. Peridium c. $20-75 \mu \mathrm{m}$ wide, pseudoparenchymatous, consisting of $(3.5-) 5.5-10(-14.5) \mu \mathrm{m}(\mathrm{n}=30)$ wide cells, dark brown outside, gradually paler, larger and thinner-walled to the inside; the innermost layer ill-defined, variably comprising hyaline or pale brown compressed cells. Hamathecium consisting of numerous branched, 1-4 $\mu \mathrm{m}$ wide, apically free paraphyses. Asci $(214-) 245-295(-317) \times(20-) 22-26.7(-28) \mu \mathrm{m}(\mathrm{n}=22)$, cylindrical to oblong or narrowly clavate, bitunicate, fissitunicate, with an ocular chamber, a short stipe and simple or knob-like base, containing (4-)8 ascospores in (obliquely) uniseriate, sometimes partly biseriate arrangement; unstable in water, stable in $3 \% \mathrm{KOH}$. Ascospores (31-)36.5-45.5(-54.5) $\times(11-) 15-$ $19.5(-23) \mu \mathrm{m}, \mathrm{l} / \mathrm{w}(2-) 2.2-2.6(-3)(\mathrm{n}=95)$, ellipsoid or broadly fusoid, with 11-14(-16) transverse and 2-4 longitudinal septa, constricted at the median or nearly median primary septum with upper part often wider than lower, thick-walled, first hyaline, turning yellowish, finally medium to dark brown, in $3 \% \mathrm{KOH}$ blackish brown; terminal part of terminal cells hyaline and broadly or narrowly rounded, projecting to c. $3.5 \mu \mathrm{m}$, becoming elongate upon germination.

Culture characteristics and asexual morph in culture - Colony radius on $\mathrm{CMD}$ at $22^{\circ} \mathrm{C}$ in the dark $4 \mathrm{~mm}$ after $1 \mathrm{wk}$, $21 \mathrm{~mm}$ after $3 \mathrm{wk}$; colony circular, thick, dense, first white, turning greyish olive, dark grey-brown and finally black, slightly zonate, becoming velvety by aerial hyphae, odour indistinct. Pycnidia developing on and around the plug submerged in the agar to superficial, globose, c. 90-300 $\mu \mathrm{m}$ diam, olivaceous to black, aggregating and confluent to large masses; peridium pseudoparenchymatous, bearing hyaline to brown hyphae and dark brown thick-walled setae 10-50 × 1.5-5 $\mu \mathrm{m}$; releasing conidia as whitish to olivaceous turbid drops. Phialides (4.5-)5.7-8.7(-11) × (1.5-)2.2-3.5(-4.2) $\mu \mathrm{m}(\mathrm{n}=30)$, lageniform, ampulliform or subcylindrical, sessile or on short few-celled conidiophores; conidia also formed on lateral pegs. Conidia (3.2-)3.5-4.7(-5.6) × (1.2-)1.4-1.8(-2.1) $\mathrm{mm}, \mathrm{I} / \mathrm{w}$ $(1.8-) 2.2-3.2(-4.3)(n=51)$, cylindrical, oblong to ellipsoid, 1 -celled, hyaline to pale greyish olivaceous, containing 2 subterminal drops, smooth.

Habitat - On Cytospora sp. (sexual and asexual morphs) on branches and twigs of Crataegus monogyna.

Distribution - Central Europe (Czech Republic, Austria). 

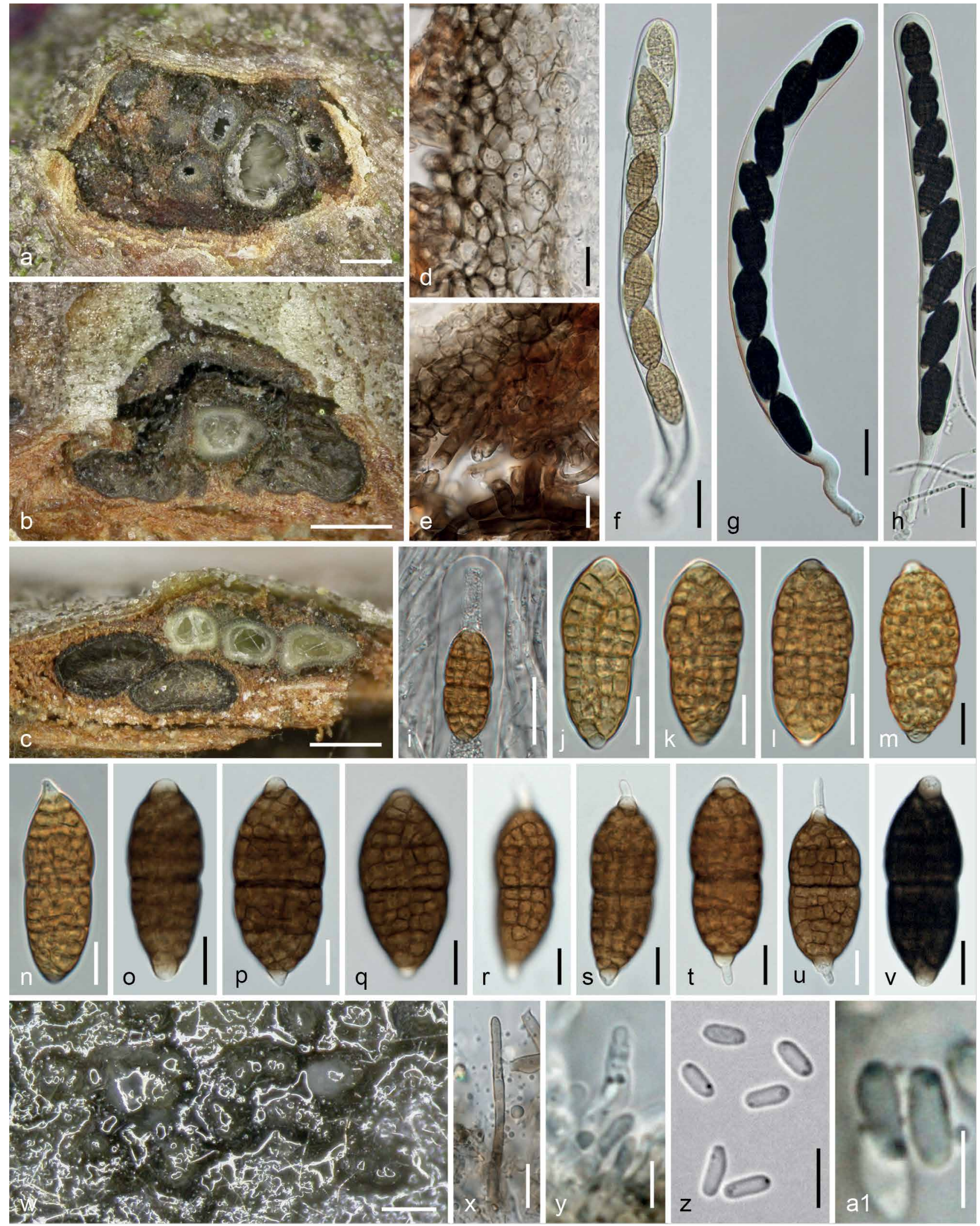

Fig. 2 Fenestella crataegi. a-v. Sexual morph. a. Horizontal section through unevenly immersed ascomata; $b-c$. Immature ascomata immersed at the ostiolar levels of the Cytospora morph (b) and the Valsa morph (c); d. peridium in vertical section; e. subicular hyphae below vertically sectioned peridium; $\mathrm{f}-\mathrm{h}$. asci (in $f$ young and opening); i. ascus apex surrounded by hamathecial threads; $j-v$. ascospores $(j-n$ from fresh material; germinating in $s-u$ ); $w-a 1$. asexual morph from CMD at $22^{\circ} \mathrm{C}$; w. pycnidia with conidial drops; $x$. pycnidial seta; y. phialides; $z-a 1$. conidia (greyish olivaceous in a1) (g-h, v. in $\left.3 \% \mathrm{KOH}\right)$. a-i, m, o-a1. WU 36987/CBS 144857 (C314); j-I, n. C287. - Scale bars: $a-c=300 \mu \mathrm{m} ; \mathrm{d}-\mathrm{e}, \mathrm{j}-\mathrm{v}, \mathrm{x}=10 \mu \mathrm{m} ; \mathrm{f}-\mathrm{i}=25 \mu \mathrm{m} ; \mathrm{w}=150 \mu \mathrm{m} ; \mathrm{y}-\mathrm{z}=5 \mu \mathrm{m} ; \mathrm{a} 1=3 \mu \mathrm{m}$ 
Other materials examined. AustRIA, Burgenland, Purbach am See, Purbacher Heide, on branch of Crataegus monogyna, 4 Feb. 2017, H. Voglmayr (culture C287; specimen lost); Niederösterreich, Wolfsthal, grid square $7868 / 3$, on corticated twigs of Crataegus monogyna, 1 Apr. 2000, W. Jaklitsch W.J. 1434 (WU 37020).

Notes - There are two specimens of Niessl labelled $\mathrm{Cu}$ curbitaria crataegi in M. Specimen M-0281852 contains a Parafenestella with ascospores (25-)26-30(-31) $\times(11.8-)$ 12.3-14(-14.3) $\mu \mathrm{m}$, recognised as $P$. austriaca (see below). It was collected in Rosenthal near Hütteldorf (Vienna, Austria), thus it cannot be type material. Specimen M-0281851 was collected at the type locality and contains a Diplodia (plus its botryosphaeriaceous sexual morph) in excess and a Massarina sp. (s.lat.) with bicellular hyaline ascospores. Also present are a few pycnidia on subiculum, containing rod-like unicellular hyaline conidia $(3-) 3.3-4(-4.4) \times(1.2-) 1.3-1.6(-1.8) \mu \mathrm{m}$, I/w 2.1-2.9(-3.7) $(n=30)$, on lageniform to subcylindrical phialides. This is presumably the asexual morph of $C$. crataegi. As the sexual morph is apparently used up and the specimen is depauperate, epitypification is essential. Von Niessl's (1872) measurements of ascospores lies at the lower end of our measurements, but his illustrations strongly suggest that our material represents this taxon, therefore we stabilise this name by epitypification rather than describing a new species. He compared his fungus with $C$. acervata, of which he had not seen authentic material.
Fenestella gardiennetii Jaklitsch \& Voglmayr, sp. nov. - MycoBank MB829742; Fig. 3

Etymology. Named after its collector Alain Gardiennet.

Holotype. France, 21, Longvic, Arboretum, on Cytospora sp. on twigs of Acer saccharum, soc. Diplodia sp., 27 June 2013, A. Gardiennet (WU 36986; ex-type culture CBS $144859=\mathrm{FM}$ ).

Ascomata (390-)405-565(-630) $\mu \mathrm{m}(\mathrm{n}=12)$ diam, depressed subglobose to globose, immersed in valsoid groups or in lines c. $0.7-2 \mathrm{~mm}$ long, also solitarily or in pairs, on and surrounded by subiculum on effete Cytospora sp.; ascoma apex mostly flat, black, sometimes partly covered by brown subiculum. Ostioles 55-150 $\mu \mathrm{m}$ diam, central, papillate to conical, black, periphysate. Subiculum consisting of subhyaline to dark brown, thick-walled, 2-6 $\mu \mathrm{m}$ wide hyphae. Peridium 20-75 $\mu \mathrm{m}$, apically to $110 \mu \mathrm{m}$ thick, pseudoparenchymatous, consisting of thick-walled, dark brown cells $(5-) 7.5-14(-17) \mu \mathrm{m}$ $(n=45)$ diam becoming gradually lighter towards the interior, sometimes terminated inside by pale brown compressed cells. Hamathecium consisting of richly branched 1-3.5 $\mu \mathrm{m}$ wide threads in a gel matrix. Asci (176-)202-243(-263) $\times(20.5-)$ 21-25.5 $(-30) \mu \mathrm{m}(\mathrm{n}=25)$, cylindrical to oblong, bitunicate, fissitunicate, with an ocular chamber, a usually short stipe and simple or knob-like base, containing 4-8 ascospores in (obliquely) uniseriate, sometimes partly biseriate arrangement. Ascospores (34-)36.5-45(-49) × (13.5-)15-19(-22.5) $\mu \mathrm{m}, \mathrm{I} / \mathrm{w}$ $(1.9-) 2.2-2.6(-2.8)(n=50)$, broadly ellipsoid to clavate, thickwalled, first hyaline with 1-4 main transverse septa, usually distinctly asymmetric with submedian primary septum and smaller lower part, developing additional septa and turning dark brown, when mature with 11-16 distinct transverse and
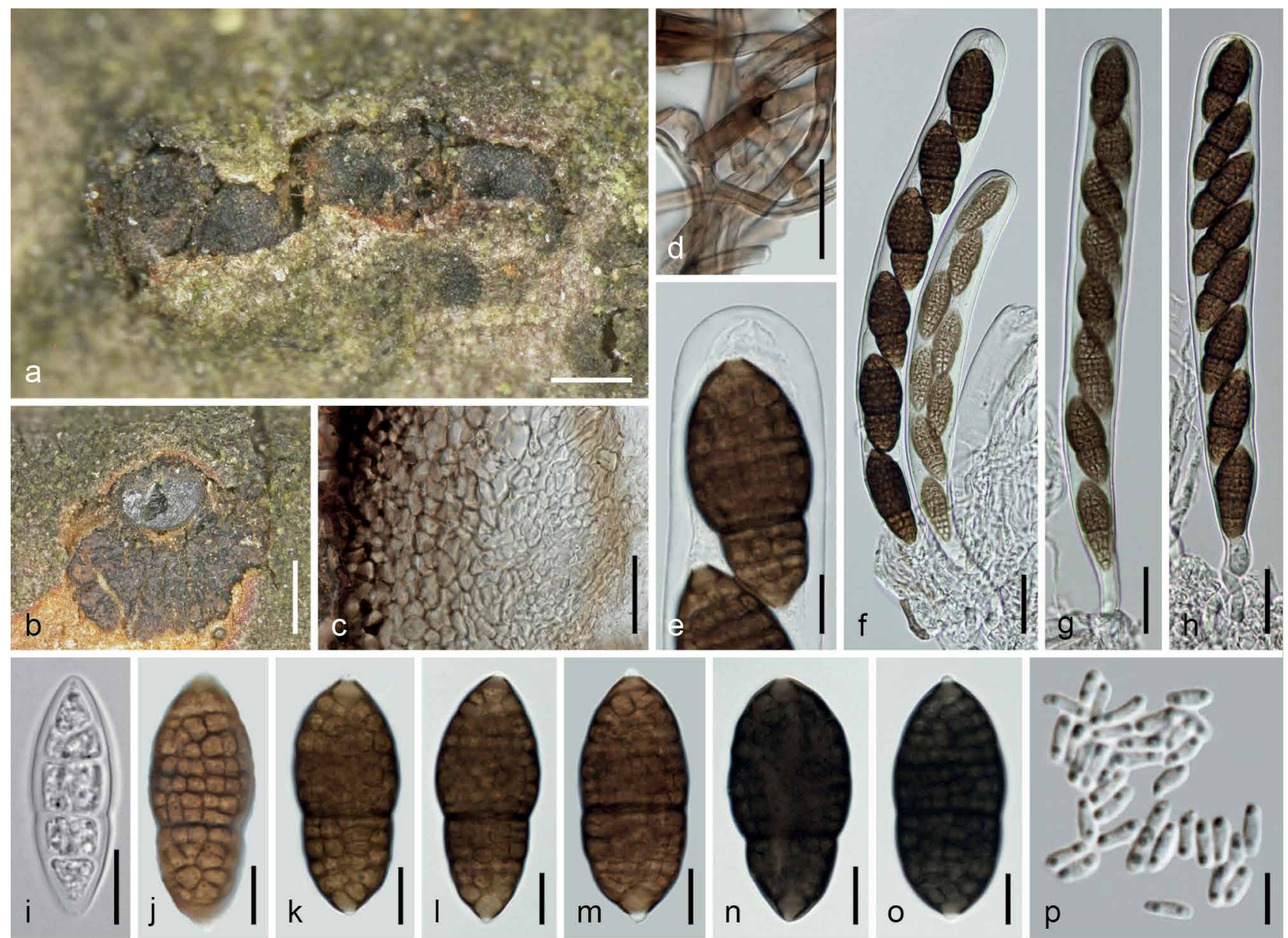

Fig. 3 Fenestella gardiennetii (WU 36986, CBS $144859=$ FM). a-o. Sexual morph. a. Ascomata in face view; b. vertical section of ascoma on a Cytospora pseudostroma; c. peridium in vertical section; d. subicular hyphae; e. ascus apex; $\mathrm{f}-\mathrm{h}$. asci; $\mathrm{i}-\mathrm{o}$. ascospores (i. initial stage); p. conidia from $\mathrm{CMD}$ at $22{ }^{\circ} \mathrm{C}$; $(n-0$. in $3 \% \mathrm{KOH})$. - Scale bars: $a=300 \mu \mathrm{m} ; \mathrm{b}=500 \mu \mathrm{m} ; \mathrm{c}-\mathrm{d}, \mathrm{f}-\mathrm{h}=25 \mu \mathrm{m} ; \mathrm{e}, \mathrm{i}-\mathrm{o}=10 \mu \mathrm{m} ; \mathrm{p}=5 \mu \mathrm{m}$. 
3-5 longitudinal septa, distinctly constricted at the primary septum; surface verruculose; ends of terminal cells concolorous or hyaline, often narrowed and projecting as 1-2 $\mu \mathrm{m}$ long apiculi; in $3 \% \mathrm{KOH}$ ascospores turning blackish brown when mature, apiculi remaining hyaline.

Culture characteristics and asexual morph in culture - Ascospores germinating simultaneously from many cells. Colony radius on $\mathrm{CMD}$ at $22{ }^{\circ} \mathrm{C}$ in the dark $10 \mathrm{~mm}$ after $1 \mathrm{wk}, 35 \mathrm{~mm}$ after 4 wk; colony circular, thick and dense, first white, turning dull olivaceous brown to brownish grey from the centre, zonate; aerial hyphae forming loose greyish mesh; reverse dark grey to black; odour indistinct. Pycnidia formed after $4 \mathrm{~d}$, mostly remaining submerged in agar and densely aggregated on and around the inoculation plug, globose, 120-210 $\mu \mathrm{m}$ diam, greenish, turning black; peridium pseudoparenchymatous, consisting of isodiametric cells with irregularly distributed dark brown pigment, surrounded by brown hyphae. Conidia amassing in pale greyish mucous drops, $(3.3-) 3.5-4.5(-5) \times(1.1-) 1.2-1.5$ $(-1.7) \mu \mathrm{m}, \mathrm{l} / \mathrm{w}(2-) 2.5-3.4(-4.4)(\mathrm{n}=30)$, cylindrical, straight to slightly curved, 1-celled, smooth, containing 2 minute guttules.

Habitat - On Cytospora sp. (sexual and asexual morphs) on Acer saccharum.

Distribution - Europe (France), only known from the type locality; possibly occurring also in North America.

Notes - Fenestella gardiennetii may have travelled on its host from North America and may thus occur also there. It is closely related to F. granatensis, which occurs on Acer granatense and differs from the former by more distinctly clavate ascospores that are surrounded by a mucous sheath.
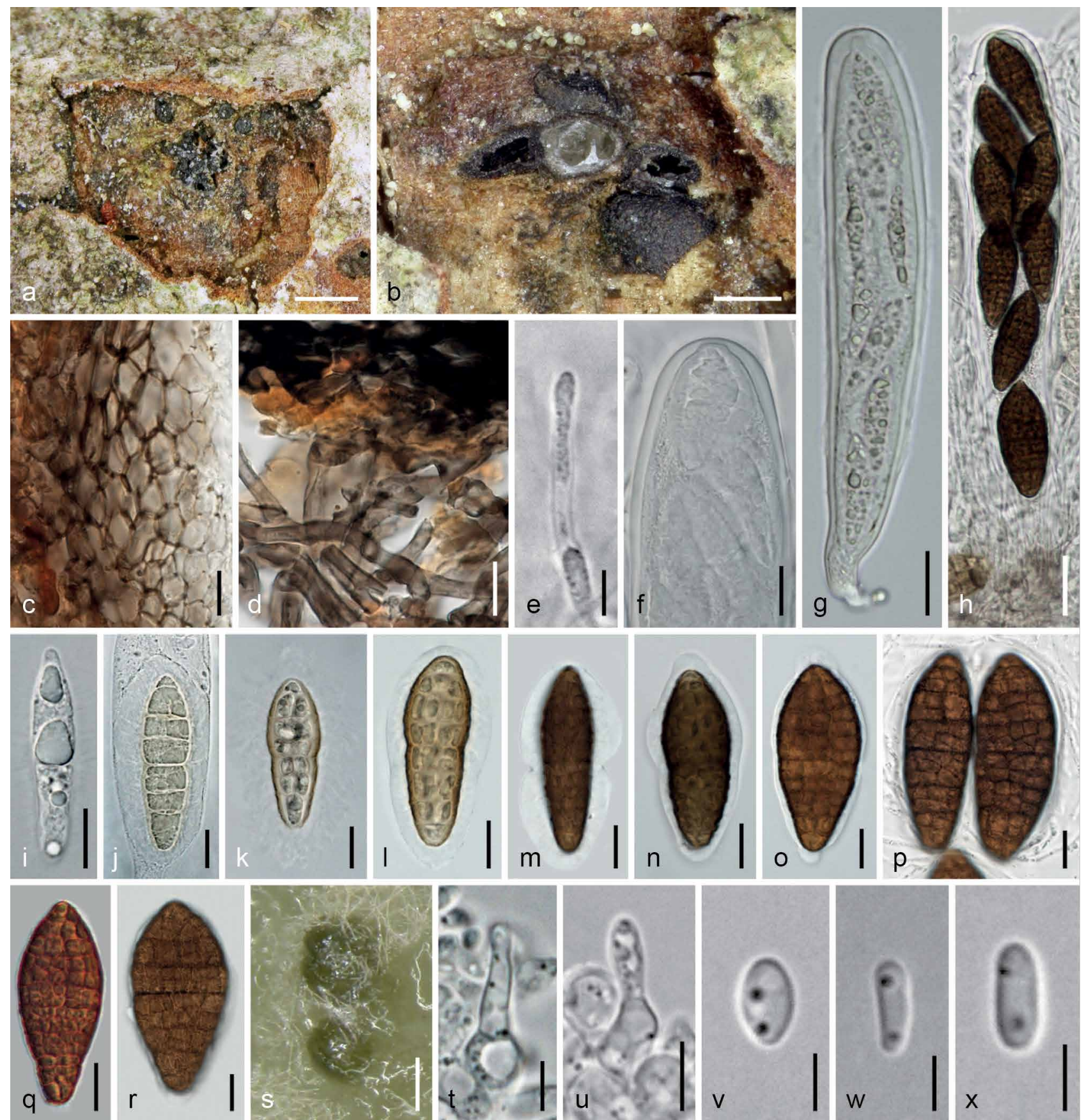

Fig. 4 Fenestella granatensis. a-r. Sexual morph (WU 36985). a. Cytospora (Valsa) pseudostroma with laterally inserted ascoma; b. vertical section of 3 ascomata sitting on a Cytospora (Valsa) ascoma; c. peridium in vertical section; $d$. subicular hyphae; e. free end of a paraphysis with sheath; f. apex of immature ascus; $g-h$. asci (immature in $g$ ); $i-r$. ascospores (i. initial stage; $j-l$. young; r. compressed); $s-x$. asexual morph (CBS 144854 (C279) from CMD at $22^{\circ} \mathrm{C}$ ); s. pycnidia; $\mathrm{t}-\mathrm{u}$. phialides; $\mathrm{v}-\mathrm{x}$. conidia (d, $\mathrm{h}, \mathrm{k}-\mathrm{I}$. in $3 \% \mathrm{KOH}$ ). - Scale bars: $\mathrm{a}=500 \mu \mathrm{m} ; \mathrm{b}=300 \mu \mathrm{m} ; \mathrm{c}-\mathrm{d}, \mathrm{f}, \mathrm{i}-\mathrm{r}=10 \mu \mathrm{m} ; \mathrm{e}, \mathrm{t}-\mathrm{u}=5 \mu \mathrm{m} ; \mathrm{g}-\mathrm{h}=20$ $\mu \mathrm{m} ; \mathrm{s}=150 \mu \mathrm{m} ; \mathrm{v}-\mathrm{x}=3 \mu \mathrm{m}$. 
Fenestella granatensis Jaklitsch \& Voglmayr, sp. nov. - MycoBank MB829743; Fig. 4

Etymology. Referring to the place of its occurrence, Granada, and its host Acer granatense.

Holotype. SpaIn, Andalusia, Granada, La Zubia, Cerro del Trevenque, near the Jardín Botanico de la Cortijuela, elev. 1600 m, on Cytospora sp. on twig of Acer granatense, soc. Dictyoporthe sp., a melanommataceous fungus, and Myriangium durieui, 14 May 2014, W. Jaklitsch \& S. Tello (WU 36985; ex-type culture CBS 144854 = C279).

Ascomata (330-)358-636(-900) $\mu \mathrm{m}(\mathrm{n}=20)$ diam, globose, depressed subglobose to subpyriform, immersed and erumpent through bark fissures, in valsoid groups of 1-10 typically around ostiolar necks of Cytospora (Valsa) ascomata, forming pustules $0.9-2 \mathrm{~mm}$ diam; individually surrounded by whitish to dark brown subiculum consisting of thick-walled, 2-7 $\mu \mathrm{m}$ wide hyphae. Ostiolar structures short-cylindrical, hardly noticeable on the surface or appearing as black dots 75-170(-210) $\mu \mathrm{m}$ diam; interior periphysate. Peridium c. $30-65 \mu \mathrm{m}$, apically to $100 \mu \mathrm{m}$ thick, pseudoparenchymatous, consisting of thick-walled, dark brown cells $(4.5-) 6-11.5(-16) \mu \mathrm{m}(n=40)$ diam becoming gradually lighter towards the interior, sometimes terminated inside by pale brown compressed cells. Hamathecium consisting of numerous, richly branched, $1-3 \mu \mathrm{m}$ wide, apically free paraphyses in a dense matrix. Asci (195-)222-265(-284) $\times$ (28.5-)31-34(-34.5) $\mu \mathrm{m}(\mathrm{n}=15)$, cylindrical, oblong or clavate, bitunicate, fissitunicate, with an ocular chamber, a usually short stipe and simple or knob-like base, containing 4-8 ascospores in (obliquely) uni- to biseriate arrangement. Ascospores (36.5-)43-53.5(-60) × (13-)17-22.5(-28.5) $\mu \mathrm{m}, \mathrm{l} / \mathrm{w}$ $(1.9-) 2.2-2.7(-3.4)(n=100)$, clavate, fusoid to subellipsoid with the upper part always wider than the lower, when young hyaline to yellowish and with 1-7 transverse and 1-2 longitudinal septa, eventually dark brown, with 12-17 transverse and 4-5 longitudinal septa; usually slightly constricted at the nearly median primary septum; tips of end cells slightly lighter or concolorous; cells filled with oil drops, surface warted and appearing fissured; surrounded by a bipartite, $1-2 \mu \mathrm{m}$ wide gelatinous sheath swelling in water and terminally fraying out at as variably shaped, appendage-like distortions or protuberances; in $3 \%$ $\mathrm{KOH}$ blackish brown, primary septum appearing more distinct, other septa becoming less distinct, sheath swelling indefinitely. Pycnidia of the presumed asexual morph with minute rod-like hyaline unicellular conidia on lageniform to subulate phialides on filiform conidiophores also present between ostiolar necks of the Cytospora (Valsa) host.

Culture characteristics and asexual morph in culture - Colony radius on $\mathrm{CMD}$ at $22^{\circ} \mathrm{C}$ in the dark $10-13 \mathrm{~mm}$ after $1 \mathrm{wk}$, $33 \mathrm{~mm}$ after $3 \mathrm{wk}$; colony circular, thick, dense, first white to yellowish, later turning dark olivaceous brown to dark grey, reverse black; aerial hyphae forming a dense brownish mat; odour indistinct. Pycnidia appearing after $4 \mathrm{~d}$ in the colony centre, numerous, separate or aggregating to larger complexes, globose, 150-270 $\mu \mathrm{m}$ diam, first hyaline to greenish, turning olivaceous to black; conidia becoming released in whitish turbid drops. Phialides sessile or formed terminally on cylindrical to globose intercalary cells, $(2.7-) 5-9(-11.3) \times(1.5-) 2.3-4(-5)$ $\mu \mathrm{m}(\mathrm{n}=20)$, lageniform, ampulliform to subglobose with a long neck. Conidia formed on phialides and lateral pegs, (3-)3.5$4.8(-6) \times(1.4-) 1.6-2.1(-2.7) \mu \mathrm{m}, \mathrm{I} / \mathrm{w}(1.5-) 2-2.7(-3.1)$ $(n=25)$, oblong, allantoid or narrowly ellipsoid, 1-celled, with usually 2 subterminal drops, smooth.

Habitat - On Cytospora sp. (sexual and asexual morphs) on Acer granatense.

Distribution - Europe (Spain), only known from the type locality.
Notes - Fenestella granatensis is easily recognisable by its clavate pleomassariaceous ascospores having a gelatinous sheath and by its host, Acer granatense. As with several other species of the fenestelloid clades, a few pycnidia are present on the fungal host; always discrete, globose and collapsing cupulate.

Fenestella media Tul. \& C. Tul., Select. Fung. Carpol. (Paris) 2: 208. 1863. - Fig. 5

Synonym. Fenestella macrospora Fuckel, Jahrb. Nassauischen Vereins Naturk. 25-26: 313. 1871.

Typification. Holotype of Fenestella media. FRAnCE, Meudon (close to Versailles; in the protologue: circa Versalias), Mar. 1860, parasitizing the Cytospora state of Valsa salicis (as Cytospora fagaci (Bull.), salicicola) on Salix alba (PC 0706651); donated by L.R. Tulasne to PC in 1873. Another specimen extant in PC (PC 0706650) was collected in 1892, i.e., after its first description. The material of the holotype contains numerous effete Cytospora pseudostromata in bark and only few are infected by the Fenestella with small pustules containing c. 1-4 ascomata. Lectotype of Fenestella macrospora, here designated: Germany, Hessen, Oestrich-Winkel, Reichartshausen, on twigs of Corylus avellana, L. Fuckel (G 00127659, from Herbier Barbey-Boissier, Herbier Fuckel 1894; distributed as Fungi Rhenani 2328; MBT385684). Epitype of Fenestella media and F. macrospora, here designated: AustRIA, Kärnten, St. Margareten im Rosental, shrubs between the village and Stariwald, grid square 9452/4, on Cytospora sp. on Corylus avellana, soc. Fenestella subsymmetrica, 10 Jan. 2011, W. Jaklitsch (WU 31641; MBT385685, MBT385686; ex-epitype culture CBS 144860 = FP).

Pseudostromatic pustules $0.6-3.6 \mathrm{~mm}$ diam or long, with circular, elliptic or oblong outline, lenticular, subglobose or pulvinate, erumpent from bark and projecting to c. $0.6 \mathrm{~mm}$, sometimes confluent to rows of up to $10 \mathrm{~mm}$, often compact; surface convex, plane or with sunken centre, typically with a brittle, pale brown, less commonly yellow- or dark brown disc or crust due to condensed subiculum. Ascomata (330-)450-665(-780) $\mu \mathrm{m}$ $(n=40)$ diam, globose, subglobose to pyriform or distorted by mutual pressure, loosely or densely aggregated in one or two layers, connected by subiculum, also solitary on conidiomata or ascomata of the Cytospora host. Subiculum dense or scant, present at bases, sides and/or surface of ascomata, consisting of hyaline to dark brown, thick-walled, c. 2.5-6 $\mu \mathrm{m}$ wide hyphae merging into pseudoparenchyma of the outer peridium. Ostioles $(90-) 110-210(-270) \mu \mathrm{m}(\mathrm{n}=47)$ diam, indistinct at the surface, sometimes discoid or papillate with plane or convex top and more or less circular outline, dark brown to black, often only visible upon injury showing the whitish interior; sometimes mixed with ostioles of the host. Peridium 20-90(-120) $\mu \mathrm{m}$ thick, pseudoparenchymatous, consisting of a dark brown narrow outer and a highly variable glassy hyaline inner layer, the latter often thickened in upper regions particularly when young; cells more or less isodiametric, thick-walled, (4.5-)6-12(-19) $\mu \mathrm{m}(\mathrm{n}=110)$ diam; outermost layer darkening in $3 \% \mathrm{KOH}$. Hamathecium consisting of often rather sparse, 1.5-2.5(-3) $\mu \mathrm{m}$ wide, branched and anastomosing ?paraphyses. Asci (185-) 207-294 (-328) × (18-)21-26.5 (-28) $\mu \mathrm{m}(\mathrm{n}=32)$, cylindrical to oblong, bitunicate, fissitunicate, with an ocular chamber, a usually short stipe and simple or knob-like base, containing 8 ascospores in (obliquely) uniseriate, sometimes partly biseriate arrangement. Ascospores (30-)34.5-43.5(-53.5) $\times(12-) 14-18(-21) \mu \mathrm{m}, \mathrm{I} / \mathrm{w}(1.9-) 2.2-2.7(-3.3)(\mathrm{n}=304)$, ellipsoid or broadly fusoid, thick-walled, first hyaline to yellowish with 1-5 transverse septa, asymmetric with submedian primary septum, developing additional septa, turning yellowish brown, when mature with often indistinct, 11-18 transverse and 3-6(-7) longitudinal septa, yellow- to golden brown when fresh, medium to dark brown when dried; surface verruculose; often upper part wider than lower; terminal cells concolorous or hyaline, often narrowed and projecting as 1-2 $\mu \mathrm{m}$ long apiculi, becoming longer $(3-4 \mu \mathrm{m})$ when old; germinating from apiculi; 

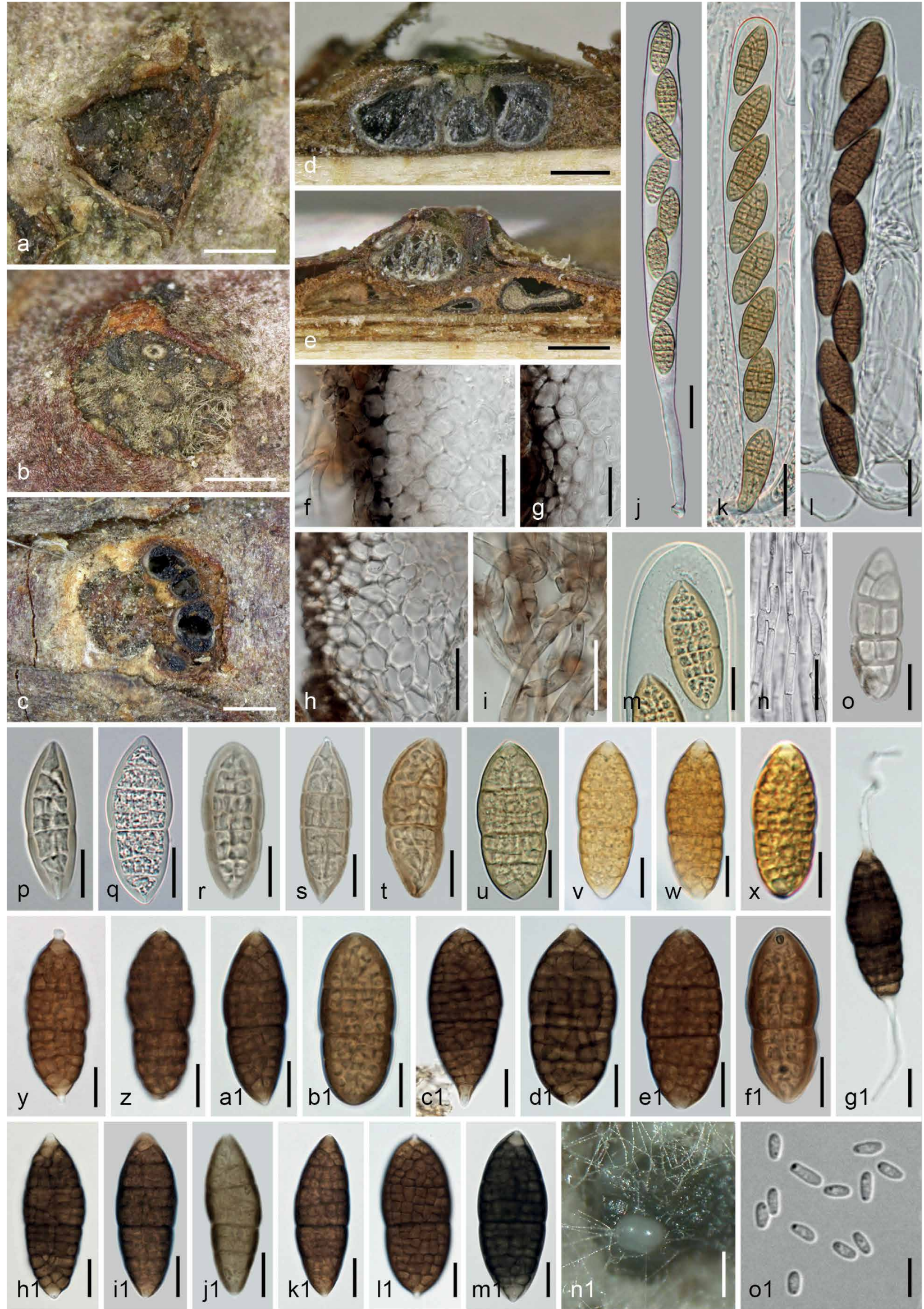

Fig. 5 Fenestella media. a-m1. Sexual morph. a-c. Pseudostromatic pustules in face view (obliquely sectioned to expose ascomata in c); d-e. ascomata in vertical section (e. above peripheral Cytospora (Valsa) ascomata); $\mathrm{f}-\mathrm{h}$. peridium in vertical section; i. subicular hyphae; $j-\mathrm{l}$. asci (j-k. young); $\mathrm{m}$. apex of young ascus; $\mathrm{n}$. section of hamathecium; $\mathrm{o}-\mathrm{m} 1$. ascospores (o-u. initial and young stages; $v-\mathrm{x}$. from fresh material; g1. germinating); $\mathrm{n} 1-01$. asexual morph from CMD at $22{ }^{\circ} \mathrm{C}$; $\mathrm{n} 1$. pycnidia; 01. conidia (f-g, j1-m1 in $\left.3 \% \mathrm{KOH}\right)$. a, j, n, q. WU 36970 (FCO); b, h1. WU 36972 (FP3); c, f, i, l, s, e1, j1. lectotype of F. macrospora (G 00127659); d, v, w, c1, i1, k1, I1, n1, o1. WU 31641/CBS 144860 (FP); e, z, d1, g1. WU 36967; g, o, t, f1. holotype of F. media (PC 0706651); h, p. WU 15513; k, m, u. WU 36974 (FP10); r, m1. WU 36971 (FP1); x. WU 36973 (FP7); y. WU15069; a1. WU 36969; b1. WU 36968. - Scale bars: a-c= $500 \mu \mathrm{m} ; \mathrm{d}-\mathrm{e}=300 \mu \mathrm{m} ; \mathrm{f}-\mathrm{i}=20 \mu \mathrm{m} ; \mathrm{j}-\mathrm{l}=25 \mu \mathrm{m} ; \mathrm{m}-\mathrm{m} 1=10 \mu \mathrm{m} ; \mathrm{n} 1=100 \mu \mathrm{m} ; 01=5 \mu \mathrm{m}$. 
in $3 \% \mathrm{KOH}$ ascospores turning olivaceous when young and dark to blackish brown when mature, apiculi remaining hyaline.

Culture characteristics and asexual morph in culture - Ascospores germinating simultaneously from many cells. Colony radius on $\mathrm{CMD}$ at $22{ }^{\circ} \mathrm{C}$ in the dark $23 \mathrm{~mm}$ after $4 \mathrm{wk}$; colony thick, dense, aerial hyphae forming dense white to pale grey mat on pale brown mycelium, sometimes turning citrine and citrine pigment diffusing into agar, centre turning black by crowded pycnidia amassing from 4 days, eventually entire colony brown, reverse grey, slightly zonate; odour indistinct. On MEA colony soon turning brown, numerous pycnidia formed. Pycnidia when formed usually covered by aerial hyphae, $120-210 \mu \mathrm{m}$ diam, more or less globose, greyish brown to black, discrete, crowded, later fusing and forming clusters or irregular stromatic masses. Conidia forming whitish to brown turbid drops, (2.2-)3-4(-4.6) $\times(1-) 1.3-1.6(-2) \mu \mathrm{m}, \mathrm{I} / \mathrm{w}(1.4-) 1.8-2.8(-3.9) \mu \mathrm{m}(\mathrm{n}=70)$, oblong to narrowly ellipsoid, hyaline, 1-(rarely 2-)celled, smooth, with 1-2 subapical guttules.

Habitat - On Cytospora spp. (sexual and asexual morphs) on various deciduous trees and shrubs, particularly common on Corylus avellana.

Distribution - Europe, possibly North America; locally common in winter.

Other materials examined (all on Cytospora spp. on corticated twigs and branches): AustRIA, Kärnten, St. Margareten im Rosental, shrubs between the village and Stariwald, grid square $9452 / 4$, on Corylus avellana, partly overgrown by Exidia sp., 24 Feb. 1992, W. Jaklitsch (WU 15069); ibid., on stem of Rubus idaeus, soc. ?Neocucurbitaria sp. (possibly on Apioporthe vepris), 31 Dec. 1994, W. Jaklitsch W.J. 412 (WU 36965); ibid., on Corylus avellana, 31 Dec. 1994, W. Jaklitsch W.J. 413 (WU 36966); ibid., on Corylus avellana, 7 Jan. 1994, W. Jaklitsch (WU 15513); ibid., on Corylus avellana, 24 Oct. 1993, W. Jaklitsch (WU 15786); ibid., on Acer pseudoplatanus, soc. Thyridaria sp. s.lat., 28 Dec. 2013, W. Jaklitsch (WU 36972; culture FP3); St. Margareten im Rosental, Gupf, grid square 9452/4, on Corylus avellana, soc. Massarina s.lat., 15 Apr. 1995, W. Jaklitsch W.J. 564 (WU 36967); Gupf, grid square 9452/2, on Corylus avellana, soc. Fenestella subsymmetrica, 8 Nov. 2013, W. Jaklitsch (WU 36971; culture FP1); Niederösterreich, Maissau, grid square 7460/2, on Corylus avellana, 26 Oct. 1995, W. Jaklitsch W.J. 764 (WU 36968); Mauerbach, close to the cemetery, grid square 7763/1, on Carpinus betulus, 28 Sept. 1996, W. Jaklitsch W.J. 964 (WU 36969); Oberösterreich, Schärding, Raab, Rothmayrberg, grid square 7648/1, on Corylus avellana, mostly immature, 5 Sept. 2009, H. Voglmayr (WU 32630); Wetzlbach, on Tilia cordata, 13 Aug. 2017, H. Voglmayr (WU 36971; culture FP10); Steiermark, Steinberg, on Castanea sativa, 3 Nov. 2015, H. Voglmayr \& W. Jaklitsch (WU 36970; culture FP7). - CRoATIA, Istrija, NE Pula, near Krnica, on Carpinus orientalis, 25 Sept. 2010, H. Voglmayr (WU 36970; culture FCO).

Notes - This is one of three cryptic species difficult to identify morphologically. Characteristic for F. media is the asymmetric ascospore septation. See also notes under $F$. subsymmetrica and $F$. viburni. As the fungus is not specific for the plant host, we use a specimen on Corylus for epitypification. Fructifications of F. media can be found particularly in winter, after the Cytospora has become old. Size and development of pseudostromata vary considerably. The largest pseudostromata occur on Corylus and may be locally very common. In contrast to Barr (1990), who considered $F$. macrospora as a synonym of $F$. fenestrata (as $F$. princeps), F. macrospora is clearly a synonym of $F$. media. Nonetheless, morphological identification of some older, noncultured and non-sequenced specimens here included under examined specimens is not always easy and therefore at least in part, tentative.

Fenestella parafenestrata Jaklitsch \& Voglmayr, sp. nov. MycoBank MB829744; Fig. 6

Etymology. Referring to the close relationship with Fenestella fenestrata.

Holotype. AustRIA, Oberösterreich, Raab, Wetzlbach, on Cytospora (Valsa) sp. on a branch of Quercus robur, 24 Feb. 2018, H. Voglmayr (WU 36988; ex-type culture CBS $144856=$ C306).
Ascomata (420-)460-610 $(-690) \mu \mathrm{m}(\mathrm{n}=15)$ diam, globose, subglobose to pyriform, immersed in and erumpent from bark, solitary or in small groups of usually less than 10 individuals forming pustules $0.5-2.2 \mathrm{~mm}$ diam on and connected by subiculum on or associated with conidiomata or ascomata of Cytospora (Valsa) sp. in the ostiolar region of the latter. Pustule surface brownish by compacted subiculum or blackened by spore deposits. Ostiolar areas 90-240(-270) $\mu \mathrm{m}$ diam, dark brown, flat or convex disc-like or irregular, sometimes slightly papillate. Subiculum consisting of thick-walled, hyaline to greyish or dark brown, 2-7 $\mu \mathrm{m}$ wide hyphae merging with the outer peridial layer. Peridium 20-75 $\mu \mathrm{m}$ thick, pseudoparenchymatous, consisting of (5-)7.5-14(-16.5) $\mu \mathrm{m}(\mathrm{n}=37)$ wide cells, dark brown, gradually paler toward the interior, at the ostiole to $100 \mu \mathrm{m}$ wide and paler with (sub-)hyaline cells toward the interior; inside compressed brownish cells present. Hamathecium consisting of numerous richly branched, 1-3 $\mu \mathrm{m}$ wide ?paraphyses. Asci $(216-) 241-320(-342) \times(21-) 23-27(-28) \mu \mathrm{m}(\mathrm{n}=20)$, cylindrical, bitunicate, fissitunicate, with an ocular chamber, a usually short stipe and simple or knob-like base, containing 6-8 ascospores in (obliquely) uniseriate arrangement; unstable in water; biseriate rearrangement and long stipes generated by pressure. Ascospores (32-)41.5-52.5(-61) × (13-)15-19(-23) $\mu \mathrm{m}, \mathrm{I} / \mathrm{w}(2.1-) 2.4-3.1(-3.6)(\mathrm{n}=100)$, ellipsoid with upper part usually broader than lower, constricted at the median to submedian primary septum, thick-walled, hyaline to yellowish and with 3-5(-8) transverse septa and 1 longitudinal septum when young, turning yellow-brown to dark brown and with 11-16(-20) transverse and 2-4 longitudinal septa; terminal cells concolorous or hyaline at the tips and often with 1-4 $\mu \mathrm{m}$ long acute apiculi; smooth, containing minute guttules; in $3 \%$ $\mathrm{KOH}$ mature spores turning blackish brown. Pycnidia of the presumed asexual morph sometimes associated with ascomata on the natural host.

Culture characteristics and asexual morph in culture - Colony radius on $\mathrm{CMD}$ at $22^{\circ} \mathrm{C}$ in the dark $8 \mathrm{~mm}$ after $1 \mathrm{wk}, 26 \mathrm{~mm}$ after $4 \mathrm{wk}$; colony thick, dense, slightly zonate, white, turning cream to pale brownish, releasing bright yellow pigment diffusing into surrounding agar, centre turning olivaceous to dark brown due to pycnidia, surface velvety by a white to pale greyish or brownish mat of aerial hyphae; reverse yellow-brown, dark brown in the centre; odour indistinct to pleasant or leathery. Pycnidia appearing after $4 \mathrm{~d}$ below white aerial hyphae, (90-) 150-330 $\mu \mathrm{m}$ diam, globose, black, first hyaline to greenish, turning olivaceous and eventually black, surrounded by brown hyphal appendages, numerous, tightly aggregated and fusing into stromatic masses to c. $2 \mathrm{~mm}$ diam with many ostioles releasing conidia as turbid whitish to olivaceous drops; peridium thin, pseudoparenchymatous. Phialides (4-)4.5-6.3(-6.6) $\times$ $(1.8-) 2-3.5(-4) \mu m(n=12)$, sessile, subglobose to ampulliform to conical. Conidia (2.5-)3-4(-4.7) $\times(1-) 1.1-1.5(-2) \mu \mathrm{m}$, $\mathrm{I} / \mathrm{w}(1.9-) 2.4-3.2(-3.9)(\mathrm{n}=65)$, cylindrical, oblong to suballantoid or narrowly ellipsoid, smooth, with 1-2 subterminal guttules.

Habitat - On Cytospora (Valsa) spp. on deciduous trees, confirmed for Quercus and Salix.

Distribution - Europe.

Other specimens examined. AustRIA, Burgenland, Mattersburg, Starembühl / Rosaliengebirge, on Cytospora (Valsa) sp. on attached twig of Quercus petraea, 1 Oct. 2001, W. Jaklitsch W.J. 1815 (WU 36990); Oberösterreich, Raab, Wetzlbach, on Cytospora (Valsa) sp. on a branch of Salix sp., $31 \mathrm{Mar}$. 2018, H. Voglmayr (WU 36989; culture C317).

Notes - This species is morphologically intermediate between F. fenestrata and the cryptic species F. media, F. subsymmetrica and $F$. viburni. See also notes under $F$. fenestrata. 

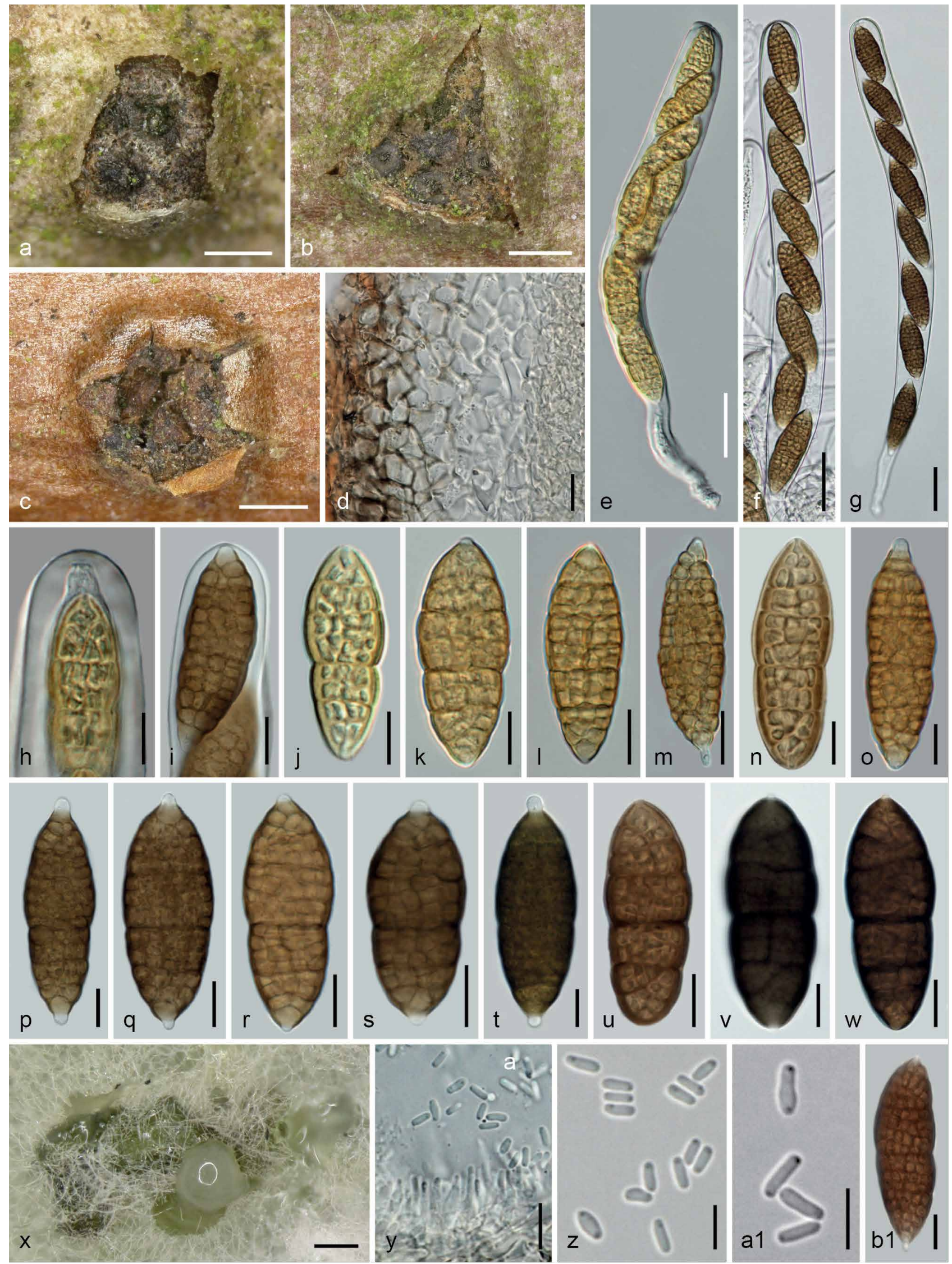

Fig. 6 Fenestella parafenestrata. a-w. Sexual morph. a-c. Ascomatal groups connected by subiculum erumpent through bark fissures in face view; d. peridium in vertical section; e-g. asci (e. young, from fresh material); $h-i$. ascus apices (immature in h); $j-w$. ascospores (j-k. young; $j, I-0$. from fresh material); $\mathrm{x}-\mathrm{a} 1$. asexual morph from $\mathrm{CMD}$ at $22{ }^{\circ} \mathrm{C}$; $\mathrm{x}$. pycnidia; $\mathrm{y}$. phialides and conidia; $\mathrm{z}-\mathrm{a} 1$. conidia; b1. ascospore of Fenestella cf. fenestrata $\mathrm{K}(\mathrm{M}) 233193$ (t, $\mathrm{v}$. in $3 \% \mathrm{KOH}$ ). a-b, d-j, I-m, p-t, v, x, a1. WU 36988/CBS 144856 (C306); c, n-o, y-z. WU 36989 (C317); k, u, w. WU 36990 . - Scale bars: a = 300 $\mu$ m; $\mathrm{b}-\mathrm{c}=500 \mu \mathrm{m} ; \mathrm{d}, \mathrm{h}-\mathrm{w}, \mathrm{y}, \mathrm{b} 1=10 \mu \mathrm{m} ; \mathrm{e}-\mathrm{g}=30 \mu \mathrm{m} ; \mathrm{x}=200 \mu \mathrm{m} ; \mathrm{z}-\mathrm{a} 1=5 \mu \mathrm{m}$. 
Fenestella subsymmetrica Jaklitsch \& Voglmayr, sp. nov. MycoBank MB829745; Fig. 7

Etymology. Referring to the nearly symmetric shape of ascospores due to the submedian to median insertion of the primary septum.

Holotype. AustRIA, Vienna, 21st district, at Marchfeldkanalweg near Felix Slavikstraße, on/soc. Cytospora holomorph on Acer campestre, soc. Diplodia sp., Fusarium sp., 8 Nov. 2015, W. Jaklitsch (WU 36979; ex-type culture CBS $144861=$ FP6 $)$.
Pseudostromatic pustules 0.7-3.4 mm wide or long, with circular, elliptic or oblong outline, subglobose or pulvinate, erumpent from bark, sometimes confluent; surface usually ill-defined and irregular, convex, plane or with sunken centre, often partly covered by bark fibres or brownish condensed subiculum, pale brown to nearly black. Ascomata (300-)370-600(-765) $\mu \mathrm{m}$ $(n=49)$ diam, subglobose to pyriform or distorted by mutual pressure, often obliquely oriented and convergent toward the
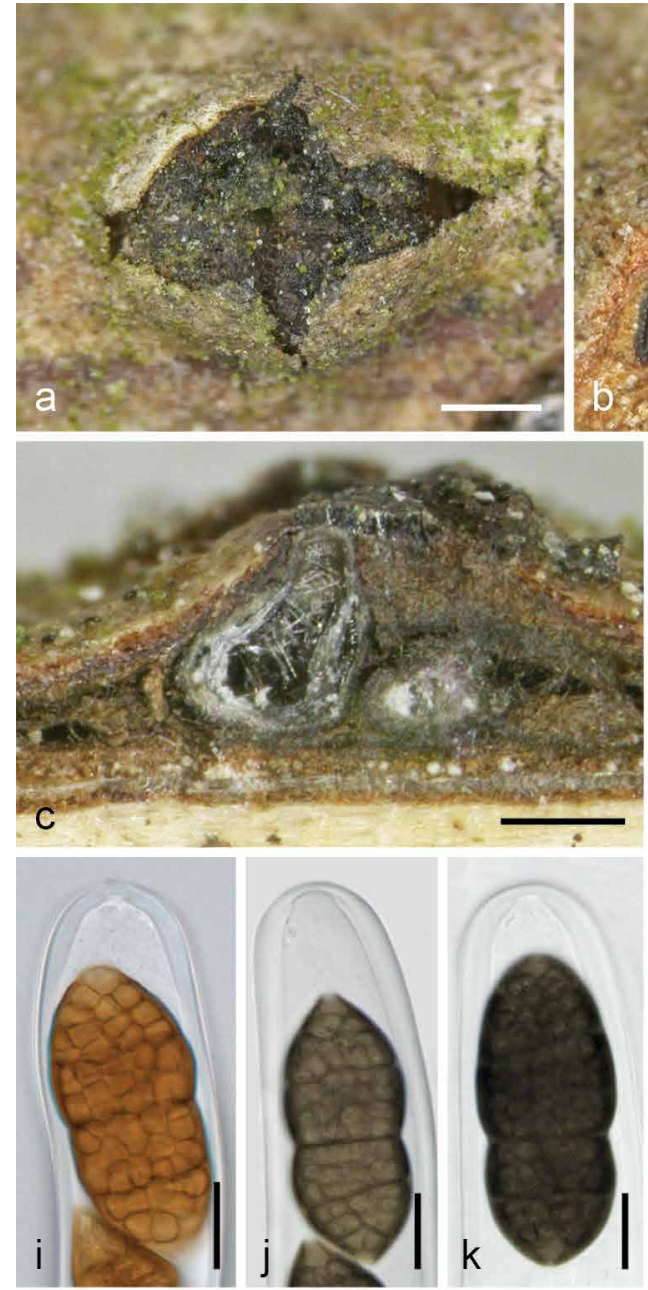
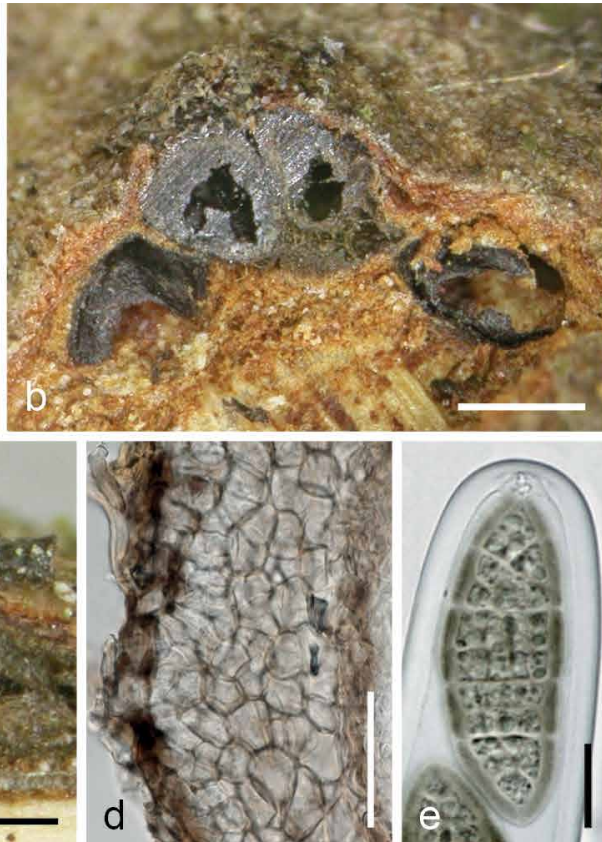
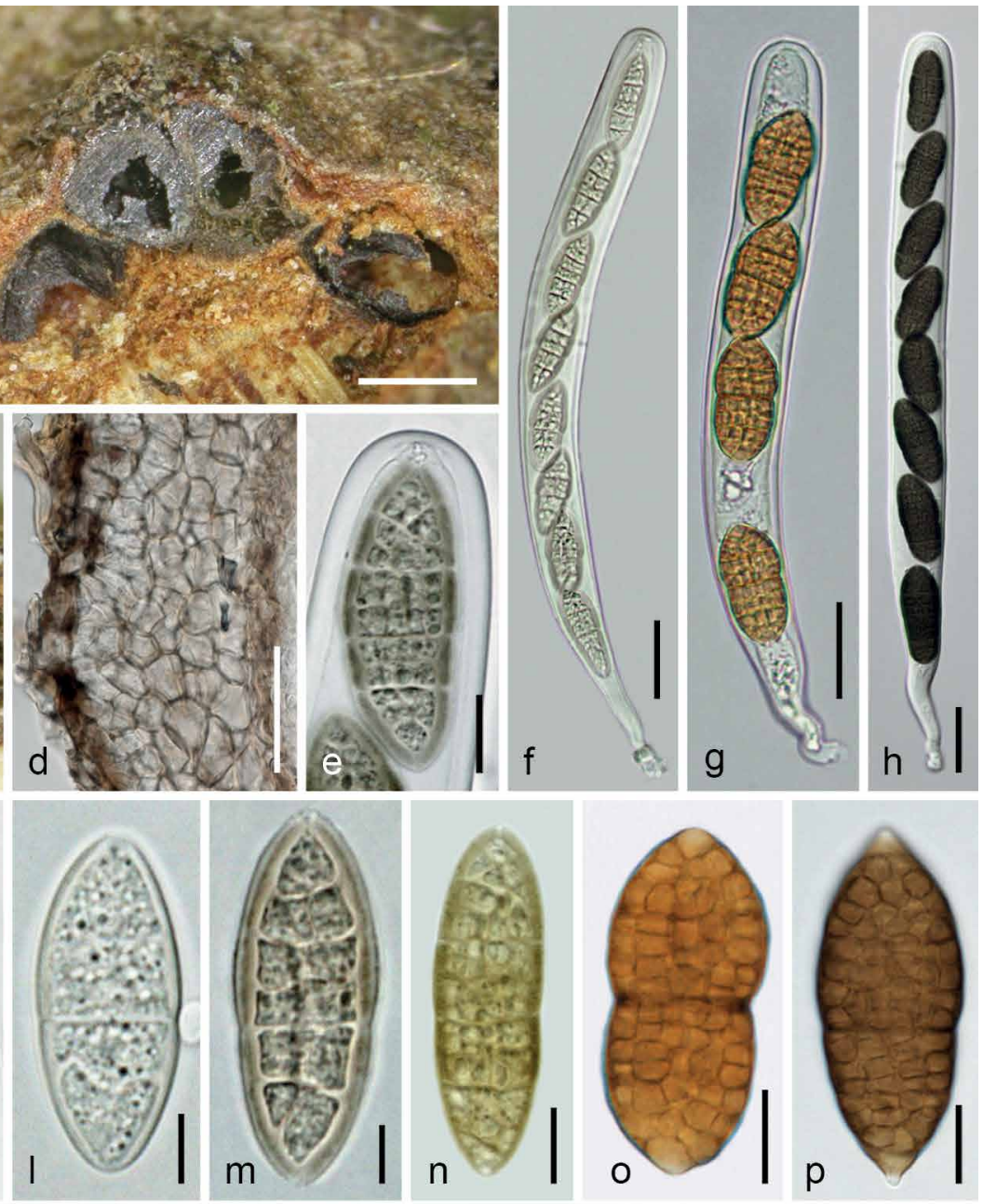

$p$
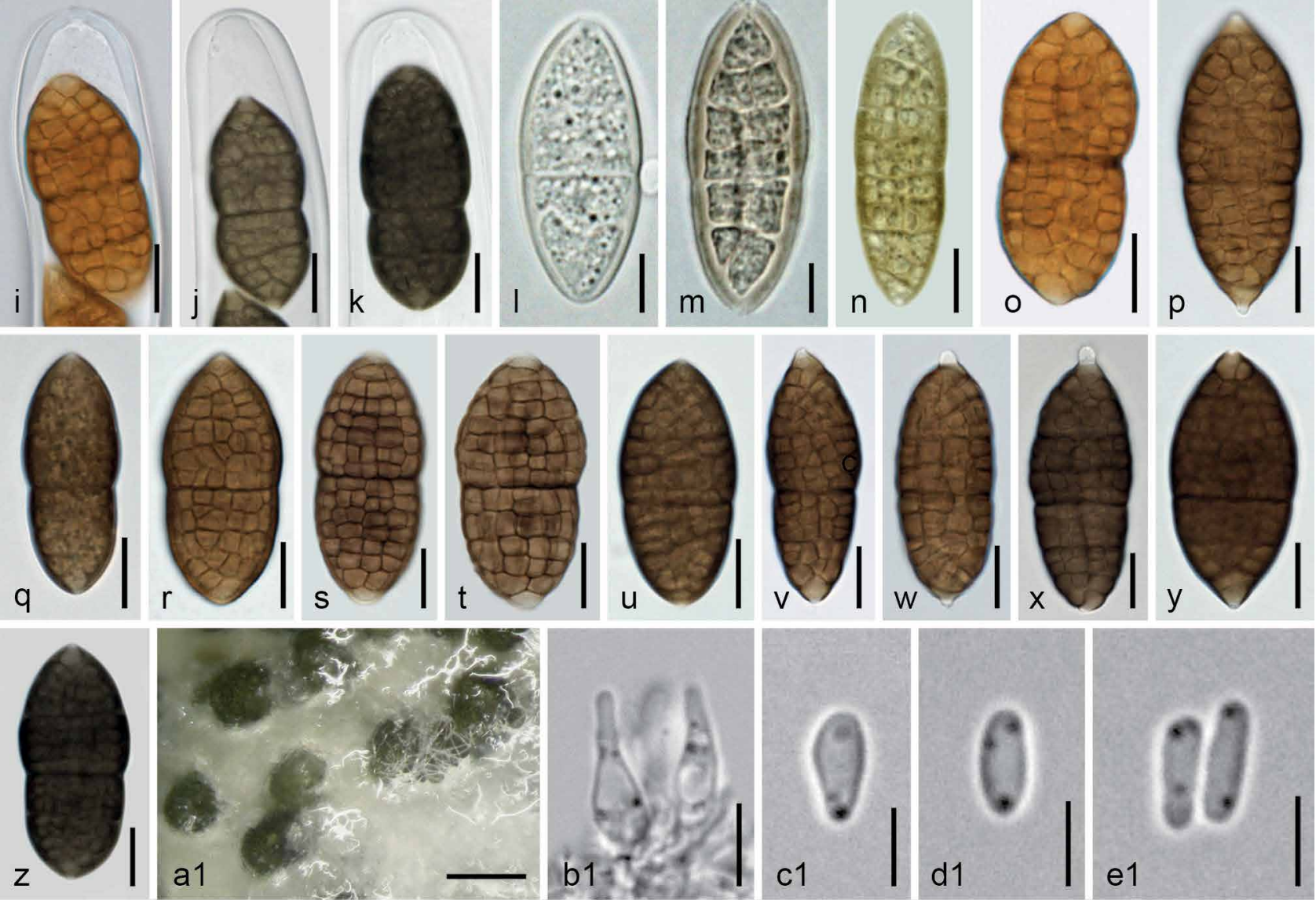

Fig. 7 Fenestella subsymmetrica. a-z. Sexual morph. a. Pseudostromatic pustule in face view; b-c. ascomata in vertical section (b. above Cytospora (Valsa) ascomata); d. peridium with subicular hyphae in vertical section; e, i-k. ascus apices (e. immature; i. from fresh material); f-h. asci (f. immature; $g$. from fresh material); $\mathrm{I}-\mathrm{z}$. ascospores (I-n. initial and young stages; o. from fresh material); a1-e1. asexual morph from $\mathrm{CMD}$ at $22^{\circ} \mathrm{C}$; a1. pycnidia; b1. phialides; $\mathrm{C} 1-\mathrm{e} 1$. conidia (e-f, h, j-k, n, z. in 3 \% KOH). a, c, o, y. WU 36978 (FP4); b, d-f, h, j, k, m-n, u, x, z-e1. WU 36979/CBS 144861 (FP6); g, i, p, s-t. WU 36975; I, r, v. WU 36977 (C286); q. WU 36976 (C285); w. WU 36980 (FP8). - Scale bars: a-b = $500 \mu \mathrm{m} ; \mathrm{c}, \mathrm{a} 1=200 \mu \mathrm{m} ; \mathrm{d}, \mathrm{f}-\mathrm{h}=25 \mu \mathrm{m} ; \mathrm{e}, \mathrm{i}-\mathrm{k}, \mathrm{n}-\mathrm{z}=10 \mu \mathrm{m}$; $\mathrm{I}-\mathrm{m}, \mathrm{b} 1=5 \mu \mathrm{m} ; \mathrm{c} 1-\mathrm{e} 1=3 \mu \mathrm{m}$. 
pustule centre, loosely or densely aggregated in valsoid or illdefined groups of up to c. 20 individuals on and connected by subiculum, sometimes fusing laterally, also solitary on conidiomata or ascomata of the Cytospora host in its ostiolar region. Subiculum present at bases, sides and/or surface of ascomata, consisting of mostly pale brown, thick-walled, 2.5-6(-7) $\mu \mathrm{m}$ wide hyphae. Ostiolar areas $(75-) 85-163(-180) \mu m(n=10)$ diam, ill-defined, irregular, often only visible by spore deposits, sometimes roundish and slightly projecting, black. Peridium 20-80(-90) $\mu \mathrm{m}$ thick, pseudoparenchymatous, consisting of a dark brown narrow outer and a glassy pale brownish to hyaline inner layer, the latter often thickened in upper regions particularly when young; cells more or less isodiametric, thick-walled, (3.5-)5.5-11(-15) $\mu \mathrm{m}(\mathrm{n}=82)$ diam; in $3 \% \mathrm{KOH}$ outermost layer turning blackish brown. Innermost part of the inner layer often slightly darker and of distinctly compressed elongate cells. Hamathecium consisting of numerous 1-3 $\mu \mathrm{m}$ wide, branched and anastomosing ?paraphyses. Asci (182-)207$302(-345) \times(19-) 21.5-25.5(-26.5) \mu \mathrm{m}(\mathrm{n}=32)$, cylindrical to oblong, bitunicate, fissitunicate, with an ocular chamber, a usually short stipe and simple or knob-like base, containing 4-8 ascospores in (obliquely) uniseriate, sometimes partly biseriate arrangement. Ascospores (28-)34.5-44.5(-54.5) $\times$ (13-)15.5-19.5(-24.5) $\mu \mathrm{m}, \mathrm{I} / \mathrm{w}(1.8-) 2-2.5(-2.9)$ ( $\mathrm{n}=201)$, broadly ellipsoid, oblong or broadly fusoid, thick-walled, first hyaline to yellowish with 1-4 transverse septa, asymmetric to subsymmetric, with submedian to median primary septum, developing additional septa, turning pale brown to olivaceous, when mature with distinct, 11-16(-18) transverse and 3-6 longitudinal septa and yellow- to golden brown when fresh, dark brown when dried; surface verruculose; often upper part wider than lower; terminal cells concolorous or hyaline, often narrowed and projecting as 1-2 $\mu \mathrm{m}$ long apiculi, becoming longer $(3-5 \mu \mathrm{m})$ when old; germinating from apiculi; in $3 \%$ $\mathrm{KOH}$ ascospores turning olivaceous when young and dark to blackish brown when mature, apiculi remaining hyaline.

Culture characteristics and asexual morph in culture - Ascospores germinating simultaneously from many cells. Colony radius on $\mathrm{CMD}$ at $22{ }^{\circ} \mathrm{C}$ in the dark $6 \mathrm{~mm}$ after $1 \mathrm{wk}$, c. $20 \mathrm{~mm}$ after 3-4 wk; colony white, centre turning black by pycnidia after $4 \mathrm{~d}$, soon entire colony turning grey, brownish grey to olivaceous, margin often hyaline to white, covered by a white to pale grey mat of aerial hyphae; odour indistinct; no diffusing pigment formed. Pycnidia 120-240 um diam, more or less globose, first hyaline to greenish, turning green to black, numerous, often concentrically and very densely arranged, spreading over entire colony or remaining in the centre; often covered by mats of aerial hyphae; conidia amassing in whitish to greenish turbid drops. Phialides 4.5-8 $\times 2-4 \mu \mathrm{m}$, lageniform to subglobose with a long neck. Conidia (3.2-)3.5-4.2(-4.5) $\times(1.1-) 1.3-2(-2.3)$ $\mu \mathrm{m}, \mathrm{I} / \mathrm{w}(1.7-) 1.9-3(-3.7)(\mathrm{n}=30)$, cylindrical, oblong to ellipsoid, 1-celled, hyaline, with 1-3 drops, smooth.

Habitat - On Cytospora spp. (sexual and asexual morphs) on various deciduous trees and shrubs.

Distribution - Europe, possibly North America; locally common in winter; sometimes co-occurring with F. media.

Other materials examined (all on or in pseudostromata of Cytospora spp. including their Valsa sexual morphs): AustRIA, Kärnten, St. Margareten im Rosental, Aussicht, grid square 9452/3, on branch of Corylus avellana, on Valsa morph, soc. Parafenestella sp., 8 Jan. 1994, W. Jaklitsch W.J. 91 (WU 15613); Gupf, grid square 9452/2, on Corylus avellana, soc. Fenestella media, 8 Nov. 2013, W. Jaklitsch (WU 36975; part of WU 36971); Niederösterreich, Bad Vöslau, Grossau, near Haidlhof, on old Cytospora holomorph on Salix caprea, 22 Feb. 2016, W. Jaklitsch \& H. Voglmayr (WU 36980; culture FP8); Oberösterreich, Schärding, Raab, between Riedlhof and Großrotmayr, grid square 7647/2, on branch of Corylus avellana, 18 Mar. 2015, H. Voglmayr (WU 36978; culture FP4); Vienna, 22nd district, at AGES, Spargelfeldstraße 191, on Valsa morph on cut branches of Juglans regia; soc. Diaporthe sp., 25 Jan. 2017, R. Moosbeckhofer (WU 36976; culture C285); ibid., other tree of
Juglans regia, 25 Jan. 2017, R. Moosbeckhofer (WU 36977; cultures C286, C286x).

Notes - Fenestella subsymmetrica is hardly distinguishable from F. media by morphology alone. Ascospores of F. subsymmetrica often tend to appear broader, with more distinct septa and a more median primary septum. However, individual specimens pose serious problems in morphological identification. For example, culture C286x derived from distinctly asymmetric ascospores of WU 36977 yielded ITS and LSU sequences, which are identical with those derived from symmetric ascopores. In cultures on CMD no pigment is formed. Mature asci are very unstable in water, therefore they were mostly measured and illustrated in $3 \% \mathrm{KOH}$.

\section{Fenestella viburni Jaklitsch \& Voglmayr, sp. nov. - MycoBank MB829746; Fig. 8}

Etymology. Owing to its occurrence on Viburnum spp.

Holotype. Austria, Niederösterreich, Wr. Neustadt, Markt Piesting, on the Hart N Piesting, grid square 8162/2, elev. 500 m, on Cytospora (Leucostoma) sp. on Viburnum lantana, 12 Oct. 2014, H. Voglmayr (WU 36982; ex-type culture CBS $144863=$ FVL)

Ascomata (330-)390-600 $(-720) \mu \mathrm{m}(\mathrm{n}=21)$ diam, subglobose to subpyriform, immersed singly or in small groups in the ostiolar region above ascomata or in conidiomata of Cytospora (Leucostoma) sp., less commonly forming pulvinate pseudostromatic pustules $0.7-2.5 \mathrm{~mm}$ diam with circular or oblong outline, in loose association with the fungal host, erumpent from bark. Subiculum individually surrounding ascomata and connecting them, consisting of thick-walled, pale to dark brown, 2-6 $\mu \mathrm{m}$ wide hyphae, sometimes condensed to brown crusts between ascomata. Ascomatal apices obtuse, brown, mostly 90-180 um diam; ostioles 70-150 $\mu \mathrm{m}$ diam, usually inconspicuous, rarely papillate, black, sometimes whitish. Peridium 20-60 $\mu \mathrm{m}$ thick, pseudoparenchymatous, consisting of a dark brown narrow outer and a glassy pale brownish to hyaline inner layer; cells more or less isodiametric, thick-walled, (5-)7-13.5(-17) $\mu \mathrm{m}(\mathrm{n}=40)$ diam; innermost part of the inner layer of distinctly compressed brownish cells. Hamathecium consisting of numerous, 1-3 $\mu \mathrm{m}$ wide, branched and anastomosing ?paraphyses. Asci (247-)258-295(-312) × (19-)22-26(-29) $\mu \mathrm{m}$ $(n=34)$, cylindrical to oblong, bitunicate, fissitunicate, with an ocular chamber, a usually short stipe and simple or knob-like base, containing 8 ascospores in uniseriate arrangement. Ascospores (29-)38-46(-49.5) × (12.5-)15-18(-22) $\mu \mathrm{m}, \mathrm{I} / \mathrm{w}$ (2-)2.3-2.8(-3.1) ( $n=193)$, ellipsoid or fusoid, sometimes distinctly pointed at the ends, asymmetric to subsymmetric, with submedian to median primary septum, first hyaline to yellowish, turning olivaceous, when mature yellow- to golden brown when fresh, dark brown when dried, with distinct 11-16 transverse and 3-6 longitudinal septa; surface verruculose; upper part often slightly wider than lower; terminal cells concolorous or terminally hyaline and projecting as minute, 1-2 $\mu \mathrm{m}$ long apiculi, becoming slightly longer when old; in $3 \% \mathrm{KOH}$ ascospores turning olivaceous when young and darker to blackish brown when mature, apiculi remaining hyaline.

Culture characteristics and asexual morph in culture - Ascospores germinating simultaneously from many cells. Colony radius on CMD at $22{ }^{\circ} \mathrm{C}$ in the dark $4 \mathrm{~mm}$ after $1 \mathrm{wk}, 22 \mathrm{~mm}$ after $4 \mathrm{wk}$; colony thick, dense, white, turning grey or olivaceous grey with white margin, velvety by a dense whitish to greyish mat of aerial hyphae; odour indistinct. Pycnidia appearing after $5 \mathrm{~d}$, globose, $90-250 \mu \mathrm{m}$ diam, first hyaline to olivaceous, turning black, immersed to superficial, tightly aggregated or fusing in large numbers around the inoculation plug or spreading over the colony, often covered by aerial hyphae, releasing conidia in whitish turbid drops through ostioles lined by clavate 
hyaline marginal cells; peridium thin, pseudoparenchymatous, consisting of thin-walled cells $(4.5-) 6.5-11(-14) \mu \mathrm{m}(\mathrm{n}=30)$ diam. Phialides (3.8-)4.8-7.5(-8.2) × (1.7-)2.5-4(-4.2) $\mu \mathrm{m}$ $(n=10)$, crowded, lageniform to subglobose with long neck or subulate. Conidia (3.3-)3.5-5(-6.3) × (1.4-)1.7-2.3(-2.7) $\mu \mathrm{m}$, I/w (1.6-)1.9-2.5(-3) $(n=32)$, cylindrical, oblong to ellipsoid, sometimes pinched, 1 -celled, hyaline, with 2 subterminal drops, smooth.

Habitat - On Cytospora spp. (both morphs; sexual morph of the Leucostoma type) on Viburnum spp.

Distribution - Europe.

Other materials examined. AustRIA, Kärnten, St. Margareten im Rosental, Aussicht, grid square 9452/3, on Viburnum lantana, 8 Jan. 1994, W. Jaklitsch (WU 15341); shrubs between the village and Stariwald, grid square 9452/4, on Cytospora sp. on Viburnum opulus, 24 Dec. 1995, W. Jaklitsch W.J. 814 (WU 36982); Stariwald, grid square 9452/4, on Cytospora sp. on Viburnum lantana, 10 Jan. 1995, W. Jaklitsch W.J. 454 (WU 36981). - France, Aude, Belcaire, chemin du Traouc, elev. 1050 m, on Cytospora (Leucostoma) sp. on
Viburnum lantana, 25 Oct. 2013, J. Fournier J.F.13212 (WU 36981; culture FP2).

Notes - Fenestella viburni is one of three cryptic species, morphologically most closely related to $F$. subsymmetrica, but difficult to differentiate. In individual specimens ascospores tend to be distinctly pointed terminally. Formation of pseudostromatic pustules is less pronounced and asci are more stable in water than with F. media and F. subsymmetrica. Pustules are difficult to assess, as they are usually produced basically by its Leucostoma host. Older, not sequenced specimens from Viburnum spp. are added tentatively to the list above.

Neocucurbitaria Wanas. et al., Mycosphere 8: 408. 2017, emended by Jaklitsch \& Voglmayr in Jaklitsch et al. (2018)

Type species. Neocucurbitaria unguis-hominis (Punith. \& M.P. English) Wanas. et al.
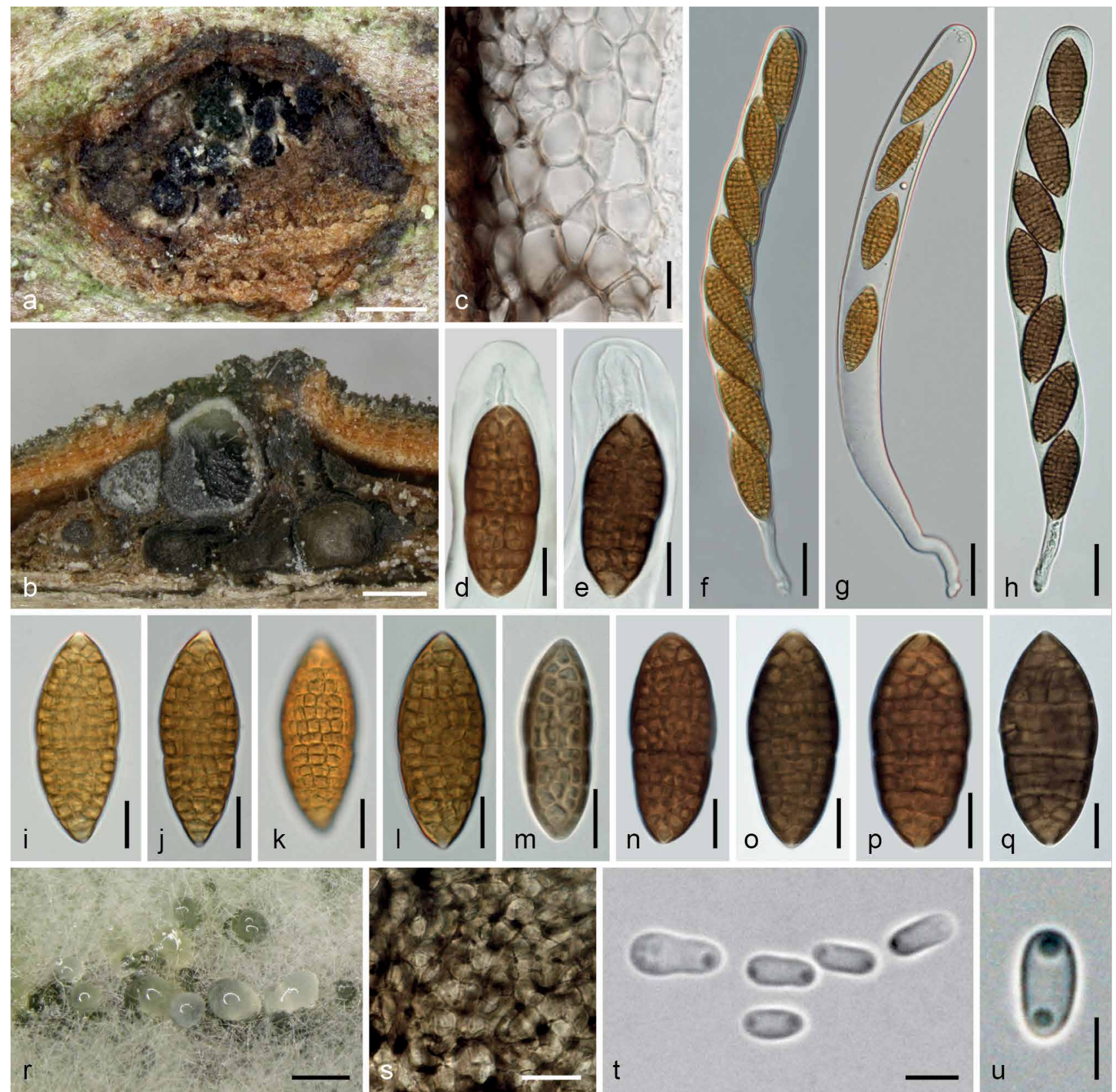

Fig. 8 Fenestella viburni. a-q. Sexual morph. a. Ascomata in face view (inserted right and left in a Cytospora (Leucostoma) pseudostroma); b. ascomata above Cytospora (Leucostoma) ascomata in vertical section; c. peridium in vertical section; $d-e$. ascus apices; $f-h$. asci ( $f-g$. from fresh material); $i-q$. ascospores (i-I. from fresh material; m. young); $r-u$. asexual morph from $C M D$ at $22{ }^{\circ} \mathrm{C}$; r. pycnidia and conidial drops; s. peridium in surface view; $t-u$. conidia. a, e, h,

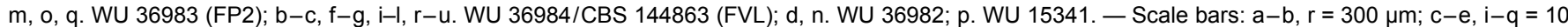
$\mu \mathrm{m} ; \mathrm{f}-\mathrm{h}=25 \mu \mathrm{m} ; \mathrm{s}=15 \mu \mathrm{m} ; \mathrm{t}-\mathrm{u}=3 \mu \mathrm{m}$. 
Notes - Neocucurbitaria juglandicola is not host-specific, as it has been recently collected on Quercus rubra, too. Cultured and sequenced material: Austria, Oberösterreich, St. Willibald, Große Sallet, on a branch of Quercus rubra, 30 Mar. 2018, H. Voglmayr (WU 36984; culture C316).

Neocucurbitaria subcaespitosa (G.H. Otth) Jaklitsch \& Voglmayr, comb. nov. — MycoBank MB829747; Fig. 9

Basionym. Cucurbitaria subcaespitosa G.H. Otth, Mitth. Naturf. Ges. Bern 711-744: 103. 1871 ' 1870 '.

Synonym. Fenestella subcaespitosa (G.H. Otth) M.E. Barr, Ann. Univ. Turku., A II 55: 14. 1974.

Lectotype, here designated: SwITZERLAND, near Bern, on twigs of Sorbus aria, without date, G.H. Otth (B 700016481; transferred from Münster in 1936; MBT385687). On the label Otth noted that he retained this material as No. 10 , a rather bad but perhaps not entirely useless part of No. 90 . He might have sent No. 90 to Nitschke for inspection. No additional material is extant in B, but according to R. Berndt (pers. comm.) Otths' material was transferred from Bern to $Z$, where a part of the type may be present but is currently not accessible. For this reason we designate B 700016481 as lectotype.

Ascomata (300-)354-550(-600) $\mu \mathrm{m}(\mathrm{n}=20)$ diam, more or less globose, immersed-erumpent from bark, loosely aggregated on subiculum in valsoid groups or in rows or firmly united by greyish or brown subiculum forming pseudostromatic pustules $0.5-2.6 \mathrm{~mm}$ diam of various shapes containing up to c. 10 ascomata; ascomata also solitary and glabrous or individually covered by brown, crust-like subiculum. Ostioles (60-)95$186(-210) \mu m(n=21)$ diam outside, papillate, or cylindrical and projecting to c. $210 \mu \mathrm{m}$, sometimes apically flattened, circular, angular or substellate in section, shiny black, whitish inside when injured. Asci cylindrical, bitunicate, containing 8 ascospores in uniseriate arrangement. Ascospores (20-)21.5$26(-29.5) \times(8-) 9-11.5(-14) \mu \mathrm{m}, \mathrm{I} / \mathrm{w}(1.9-) 2.1-2.6(-2.9)$ ( $n=81$ ), ellipsoid, with (4-)5-7(-9) distinct transverse and 1-2 longitudinal septa, distinctly constricted at the median primary septum, less distinctly at other septa, pale brown when immature, dark brown when mature, ends rounded, concolorous, surrounded by a narrow hyaline perispore swelling in $\mathrm{KOH}$ to $2 \mu \mathrm{m}$.

Habitat - On dead partly corticated twigs of Sorbus aria. Distribution - Europe.

Other material examined. AustRIA, Kärnten, St. Margareten im Rosental, Schwarzgupf, grid square 9452/4, on branch of Sorbus aria, 25 May 1997, W. Jaklitsch W.J. 1072 (WU 36991).
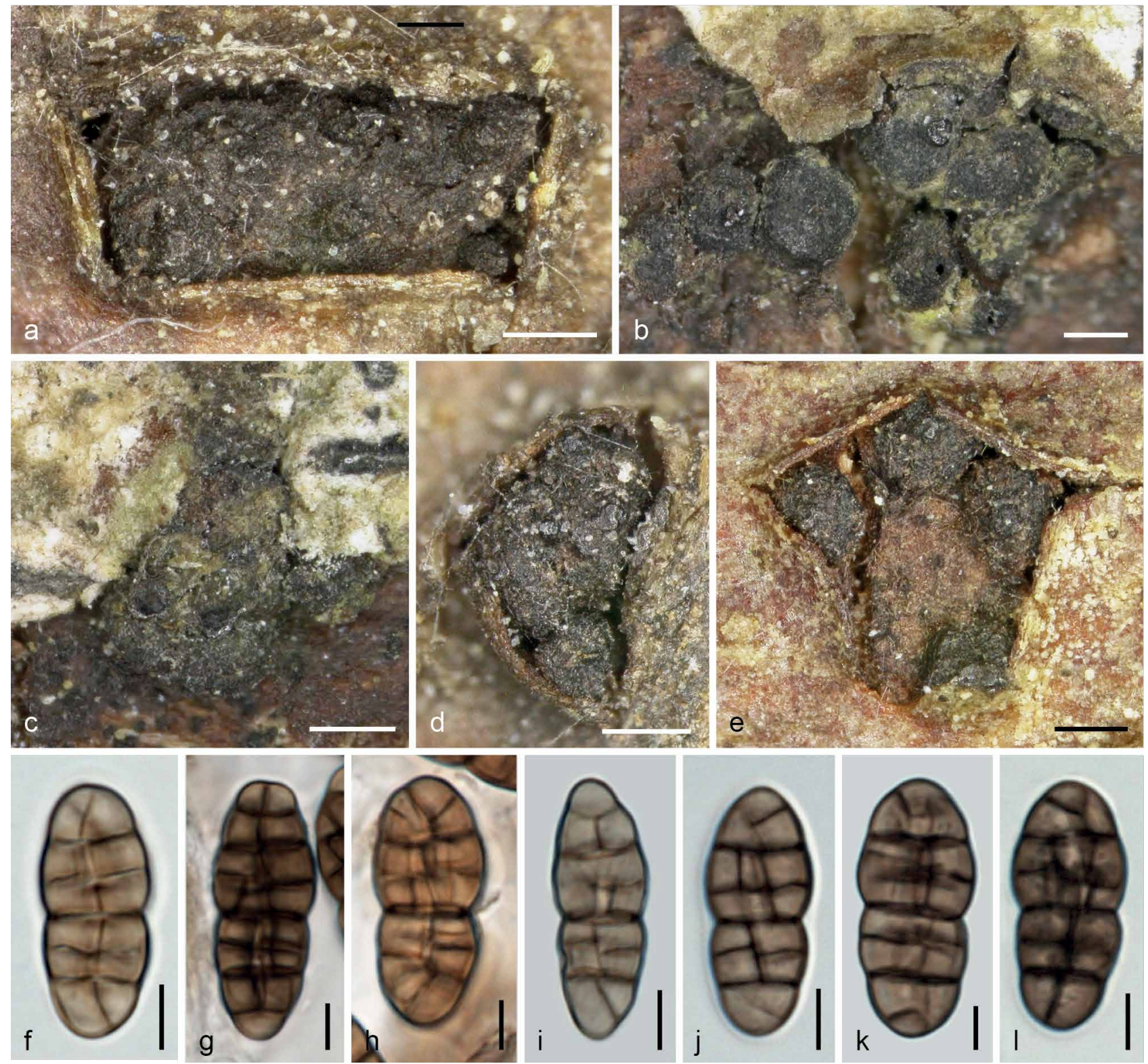

Fig. 9 Neocucurbitaria subcaespitosa. a-e. Ascomata in face view; f-I. ascospores (i-I. in 3 \% KOH). a, d-e, i-I. WU 36991; b-c, f-h. Cucurbitaria subcaespitosa holotype B 700016481 . - Scale bars: $a-e=300 \mu \mathrm{m} ; \mathrm{f}-\mathrm{I}=5 \mu \mathrm{m}$. 

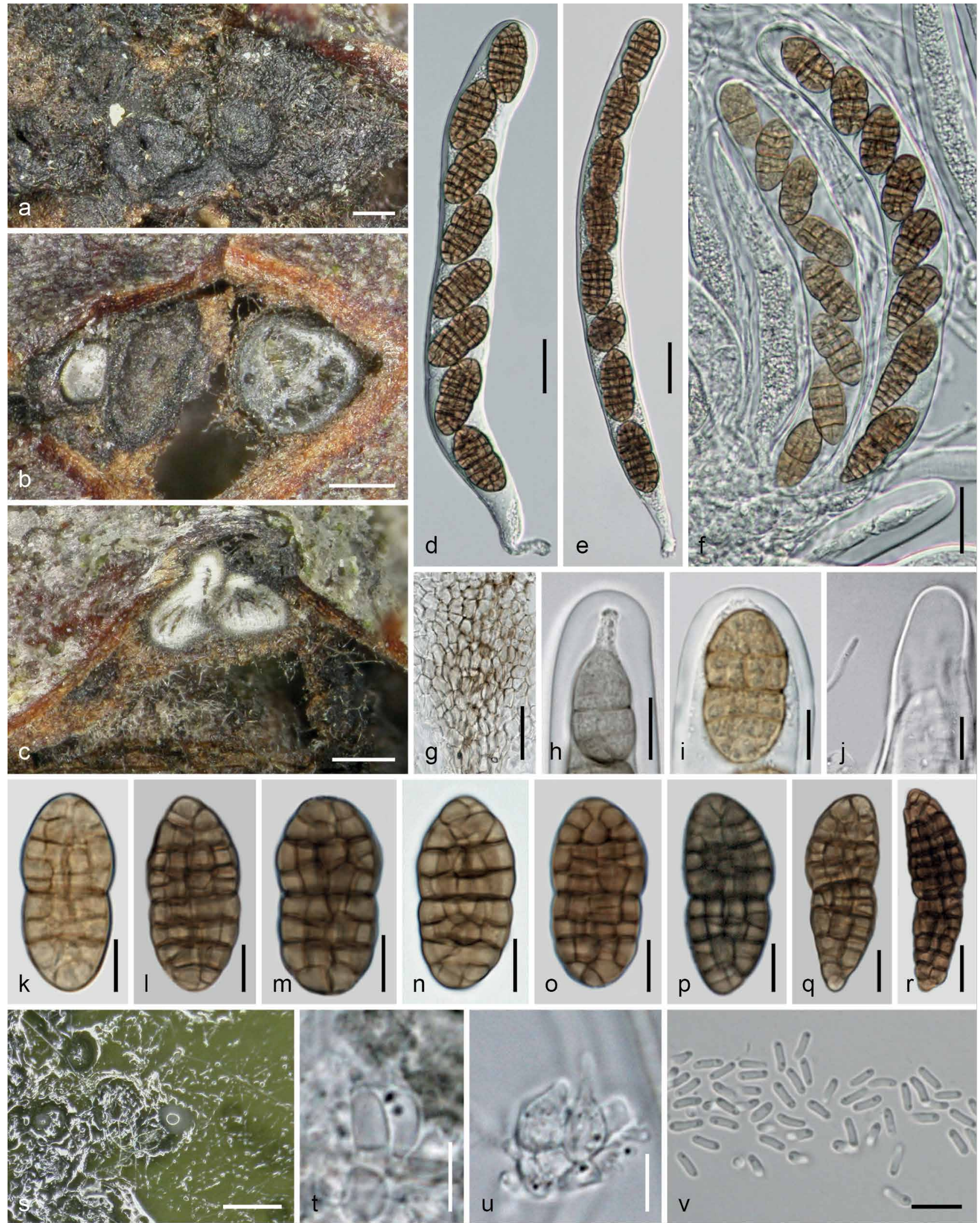

Fig. 10 Parafenestella alpina. a-r. Sexual morph. a. Ascomata in face view; b. vertical section of young ascoma above the perithecial host and one ascoma in horizontal section; $c$. vertical section of laterally fused ascomata surrounded by subiculum; $d-f$. asci; $g$. peridium of laterally fused ascomata in vertical section; $\mathrm{h}-\mathrm{i}$. ascus apices ( $\mathrm{h}$. immature); j. paraphysis tip near immature ascus apex; $\mathrm{k}-\mathrm{r}$. ascospores ( $\mathrm{k}$. young; $\mathrm{q}$, $\mathrm{r}$. aberrant); $\mathrm{s}-\mathrm{v}$. asexual morph from $\mathrm{CMD}$ at $22^{\circ} \mathrm{C}$; s. pycnidia and conidial drops; t-u. phialides; v. conidia (h, j, o. in $3 \% \mathrm{KOH}$ ). a-m, p-v. WU 36997/CBS 145263 (C198); $n-0$. WU 36998 (C249). - Scale bars: $a-c, s=200 \mu \mathrm{m} ; \mathrm{d}-\mathrm{g}=20 \mu \mathrm{m} ; \mathrm{h}, \mathrm{j}, \mathrm{r}=10 \mu \mathrm{m} ; \mathrm{i}, \mathrm{k}-\mathrm{q}, \mathrm{v}=7 \mu \mathrm{m} ; \mathrm{t}-\mathrm{u}=5 \mu \mathrm{m}$. 
Notes - In both studied specimens ascomata are overmature, and only fragments of asci allowing interpretations of ascus shape and ascospore arrangement. Our material was neither cultured nor sequenced, therefore relegation to $\mathrm{Neocu}$ curbitaria is tentative but strongly suggested by the morphology, particularly based on features of ascomata, ascospores and ostioles (compare Jaklitsch et al. 2018). Barr (1990) incorrectly synonymised this species with Cucurbitaria sorbi without having seen type material and anticipated occurrence on several Sorbus spp. in Europe and North America. However, N. subcaespitosa seems to occur only on Sorbus aria.

Parafenestella Jaklitsch \& Voglmayr, in Jaklitsch et al., Stud. Mycol. 90: 108. 2018

Type species. Parafenestella pseudoplatani Jaklitsch \& Voglmayr.

Parafenestella alpina Jaklitsch \& Voglmayr, sp. nov. - MycoBank MB829748; Fig. 10

Etymology. For its occurrence in subalpine to alpine regions.

Holotype. AustrIA, Osttirol, Prägraten am Großvenediger, Wallhorn, Bodenalm, elev. c. 2000 m, on dead attached twigs of Cotoneaster integerrimus, soc. Cytospora (Leucostoma morph) sp., Discostroma sp. (in excess), Mollisia sp., cf. Nigrograna sp., cf. Teichospora sp., 18 June 2015, W. Jaklitsch \& H. Voglmayr (WU 36997; ex-type culture CBS 145263 = C198).

Ascomata (180-)240-375(-450) $\mu \mathrm{m}(\mathrm{n}=22)$ diam, globose, subglobose or pyriform, usually tightly aggregated in bark on a perithecial host fungus in small numbers and connected by subhyaline to dark brown, thick-walled, $2-5 \mu \mathrm{m}$ wide subicular hyphae, dark brown to black; tightly packed ascomata sometimes covered by a brown to black, densely packed mesh of subicular hyphae and ejected ascospores. Ostiolar areas (53-)60$105(-135) \mu \mathrm{m}(\mathrm{n}=12)$ diam, slightly papillate, rounded, black. Peridium 15-70 $\mu \mathrm{m}$ thick, pseudoparenchymatous, consisting of isodiametric cells $(4-) 5-9.5(-12) \mu \mathrm{m}(\mathrm{n}=30)$ diam, outside moderately thick-walled and dark brown, paler to hyaline in upper regions and thinner-walled to the inside; confluent with tightly appressed ascomata. Hamathecium consisting of numerous $0.5-1 \mu \mathrm{m}$ (to $2.5 \mu \mathrm{m}$ in $3 \% \mathrm{KOH}$ ) wide, branched paraphyses with free ends. Asci (143-)170-208(-227) $\times(18-)$ 18.5-21.5(-24.5) $\mu \mathrm{m}(\mathrm{n}=25)$, cylindrical to oblong, bitunicate, fissitunicate, with a truncate ocular chamber, a short stipe and simple or knob-like base, containing 6-8 ascospores in uniseriate arrangement. Ascospores (19-)24-30.5(-35) $\times$ (10.5-)12-14(-15.5) $\mu \mathrm{m}, \mathrm{I} / \mathrm{w}(1.4-) 1.8-2.4(-2.9)(\mathrm{n}=73)$, typically ellipsoid to fusoid, often inequilateral, very variable in shape and size, from subglobose to clavate or lower part elongated fusoid, first with 1-5 main septa, constricted at the more or less median primary septum, developing (7-)8-12(-15) transverse and (2-)3-4 longitudinal septa, with upper part often broader, first hyaline to yellowish, turning medium to dark brown, blackish brown when old; ends concolorous; in $3 \% \mathrm{KOH}$ turning pale olivaceous when young and dark to blackish brown when mature or old.

Culture characteristics and asexual morph in culture - Ascospores germinating simultaneously from many cells. Colony radius on CMD at $22{ }^{\circ} \mathrm{C}$ in the dark $8 \mathrm{~mm}$ after $1 \mathrm{wk}, 25 \mathrm{~mm}$ after $3 \mathrm{wk}, 38 \mathrm{~mm}$ after $5 \mathrm{wk}$; colony dark grey to olivaceous, centre darker; aerial hyphae long, white, forming an initially loose later dense mesh above the colony; odour indistinct. Pycnidia 75-170 $\mu \mathrm{m}$ diam, (sub-)globose, papillate with a pale opening, numerous, first appearing after $3 d$, hyaline, turning greenish, olivaceous to black, mostly immersed, partially erumpent, solitary and in firm packs, spreading from the centre; conidia emitted as whitish turbid drops. Peridium thin, pseudoparenchymatous, olivaceous, surrounded by subhyaline submoniliform hyphae. Phialides 4.8-7.5(-9.3) × 2-3.5(-4.4) $\mu \mathrm{m}(\mathrm{n}=14)$, sessile, varying from subglobose over ampulliform and lageniform to subulate. Conidia $(3.4-) 3.7-4.3(-4.6) \times$ (1-)1.1-1.4(-1.5) $\mu \mathrm{m}, \mathrm{I} / \mathrm{w}(2.6-) 2.9-3.7(-3.9)$ ( $\mathrm{n}=24)$, cylindrical to allantoid, less commonly narrowly ellipsoid, 1-celled, hyaline with 2 small drops, smooth.

Habitat - On perithecial fungi on Cotoneaster integerrimus and Salix appendiculata.

Distribution - Central Europe (Austria).

Other materials examined. AUSTRIA, Steiermark, Deutschlandsberg, Koralpe, at the parking place of the walking path to the Grünanger- and Bärentalhütte; N4649'44" E1500'56", elev. c. 1540 m; on dead attached twigs of Salix appendiculata, soc. effete Plagiostoma sp., Plenodomus hendersoniae (in excess), 6 May 2016, G. Friebes (WU 36998; culture C249).

Notes - Due to the rough climate in (sub)alpine regions, asci and ascospores are often aberrantly developed. The fungal host of $P$. alpina may be Cytospora, but due to the many other fungi that are present on the specimens, this is uncertain.

Parafenestella austriaca Jaklitsch \& Voglmayr, sp. nov. MycoBank MB829749; Fig. 11

Etymology. For its occurrence in Austria.

Holotype. AustRIA, Oberösterreich, Schärding, St. Willibald, Geitzedt, grid square 7648/1, on branch of Rosa canina, 19 Mar. 2015, H. Voglmayr (WU 37014; ex-type culture CBS 145262 = C152).

Ascomata (270-)295-412(-450) $\mu \mathrm{m}(\mathrm{n}=10)$ diam, subglobose to pyriform, immersed-erumpent from bark, scattered or aggregated in small valsoid groups, often on an effete perithecial fungus, laterally collapsing from above, basally and laterally surrounded by subhyaline to dark brown, thick-walled, 2-5 $\mu \mathrm{m}$ wide, smooth to verruculose subicular hyphae turning olivaceous in $3 \% \mathrm{KOH}$. Ostiolar area $(60-) 75-128(-150)$ $\mu \mathrm{m}(\mathrm{n}=17)$ diam, convex or papillate with rounded opening, black. Peridium 15-85 $\mu \mathrm{m}$ thick, pseudoparenchymatous, consisting of isodiametric cells $(3.5-) 4-10(-14.5) \mu \mathrm{m}(\mathrm{n}=40)$ diam, outside thick-walled and dark brown, paler to hyaline in upper regions and thinner-walled to the inside; darkening in $3 \% \mathrm{KOH}$. Hamathecium consisting of numerous 1-2.5 $\mu \mathrm{m}$ wide, branched ?paraphyses in a gel matrix. Asci (150-) 159-205(-237) × 16-19.5(-24.2) $\mu \mathrm{m}(\mathrm{n}=33)$, cylindrical, bitunicate, fissitunicate, with a distinct ocular chamber, a short stipe and simple or knob-like base, containing 4-8 ascospores in uniseriate arrangement. Ascospores (25-)27-32.5(-38.2) $\times$ $(12-) 13-15(-16.5) \mu \mathrm{m}, \mathrm{l} / \mathrm{w}(1.9-) 2-2.3(-2.6)(\mathrm{n}=87)$, broadly ellipsoid with usually broadly rounded ends and upper part often wider, constricted at the median or slightly supra- or submedian primary septum, with $9-13(-14)$ distantly spaced transverse including v-septa in end cells and $3-4(-5)$ longitudinal septa, first hyaline to yellowish, with 1-3 main septa, turning yellowish brown, finally medium to dark brown or dark reddish brown with concolorous, sometimes paler to hyaline ends; surface appearing verruculose; in $3 \% \mathrm{KOH}$ wall appearing smooth, interior containing numerous minute droplets, turning greenish to yellow-green when immature, dark to blackish brown when mature.

Culture characteristics and asexual morph in culture - Colony radius on $\mathrm{CMD}$ at $22{ }^{\circ} \mathrm{C}$ in the dark $7-8 \mathrm{~mm}$ after $1 \mathrm{wk}, 16$ $\mathrm{mm}$ after $2 \mathrm{wk}, 26-27 \mathrm{~mm}$ after $23 \mathrm{~d}$; colony first white, soon turning greyish olivaceous to greyish brown; aerial hyphae forming a dense mesh above the colony hiding pycnidia; reverse dark grey to black; odour indistinct. Pycnidia c. 100-200 $\mu \mathrm{m}$ diam, subglobose with papillate to cylindrical ostioles, first appearing after $3 \mathrm{~d}$, hyaline, turning greenish, olivaceous to black, mostly immersed, scattered to densely aggregated, covered by aerial hyphae; conidia emitted as whitish turbid drops. 
Peridium thin, pseudoparenchymatous, olivaceous. Phialides (3.5-)4.2-7(-8.2) × (1.5-)2-3.2(-3.8) $\mu \mathrm{m}(\mathrm{n}=16)$, sessile or formed on short, $1-2$ celled conidiophores, varying from subglobose over ampulliform and lageniform to subulate. Conidia $(3-) 3.5-4.2(-5) \times 0.9-1.5(-2) \mu \mathrm{m}, \mathrm{I} / \mathrm{w}(2.1-) 2.6-3.7(-4.2)$ $(n=50)$, cylindrical to allantoid, less commonly narrowly ellipsoid, 1-celled, hyaline, with 2 small drops, smooth; produced on phialides and pegs. After a few transfers no pycnidia formed.
Habitat - Associated with perithecial fungi on Rosa canina and possibly Crataegus monogyna.

Distribution - Central Europe (Austria).

Notes - Von Niessl's Austrian collection from Crataegus in Rosenthal bei Hütteldorf, Vienna (M-0281852; as Cucurbitaria crataegi Niessl) is morphologically indistinguishable and therefore apparently this species. As we have not seen type material of Cucurbitaria rosae G. Winter \& Sacc. (none is present in W),
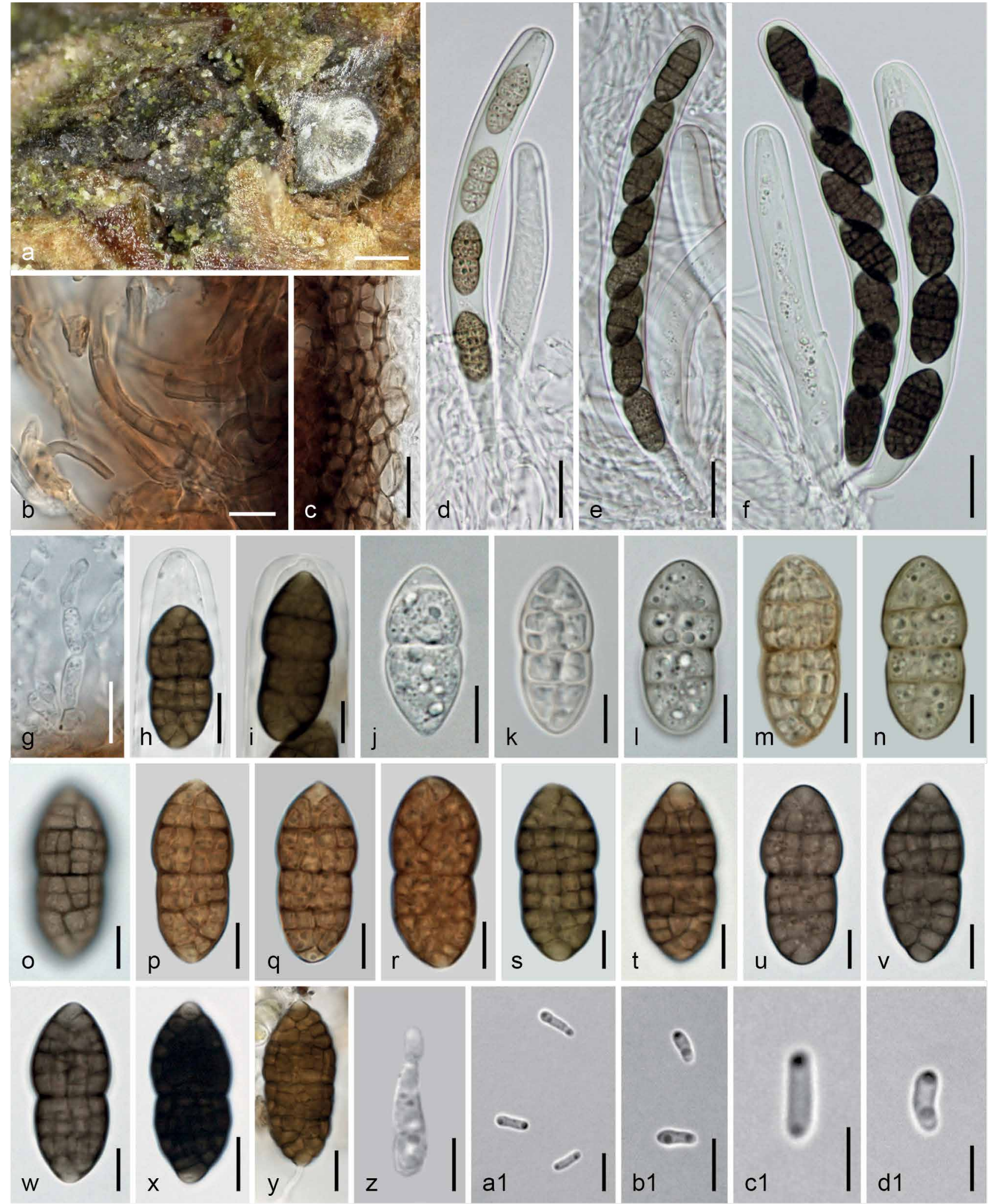

Fig. 11 Parafenestella austriaca. a-y. Sexual morph. a. Ascomata in face view and in vertical section; b. subicular hyphae; c. peridium in vertical section; $\mathrm{d}-\mathrm{f}$. asci (d. young, 4-spored); g. periphysis; $\mathrm{h}-\mathrm{i}$. ascus apices; j-y. ascospores (j-n. immature; y. germinating); $z-d 1$. asexual morph from $\mathrm{CMD}$ at $22{ }^{\circ} \mathrm{C}$; z. phialide; a1-d1. conidia. (d-f, h-i, I, n-o, s, u-x, z. in $3 \%$ KOH). a-l, n-q, s-v, y-d1. WU 37014/CBS 145262 (C152); m, r, w, x. M 0281852. - Scale bars: $a=250 \mu \mathrm{m} ; b, g-h, x-y=10 \mu \mathrm{m} ; c-f=20 \mu \mathrm{m} ; i-w=7 \mu \mathrm{m} ; z-b 1=5 \mu \mathrm{m} ; c 1-d 1=3 \mu \mathrm{m}$. 
its concept is unclear, but its protologue suggests that it may be a synonym of $C$. acervata. However, a fungus matching the description of that species in the sense of Mirza (1968) was found not belong to the Cucurbitariaceae. Another species described from Rosa is Cucurbitaria occulta Fuckel, with ascospores 16 $\times 8 \mu \mathrm{m}$ having $4-5$ transverse and 1 longitudinal septa. Its type material (Germany, Hessen, Oestrich, Oestricher Wald, erumpent on Rosa canina in the spring, Fuckel (G 00266382; Fungi rhenani 1279, from Herbier Boissier, labelled Agyrium nitidum Lib.) contains a drawing with a cylindrical ascus 102 $\times 13 \mu \mathrm{m}$ with 8 uniseriate ascospores, one ellipsoid, with $5 / 1$ septa, $16 \times 8 \mu \mathrm{m}$ and bark fragments containing the asexual
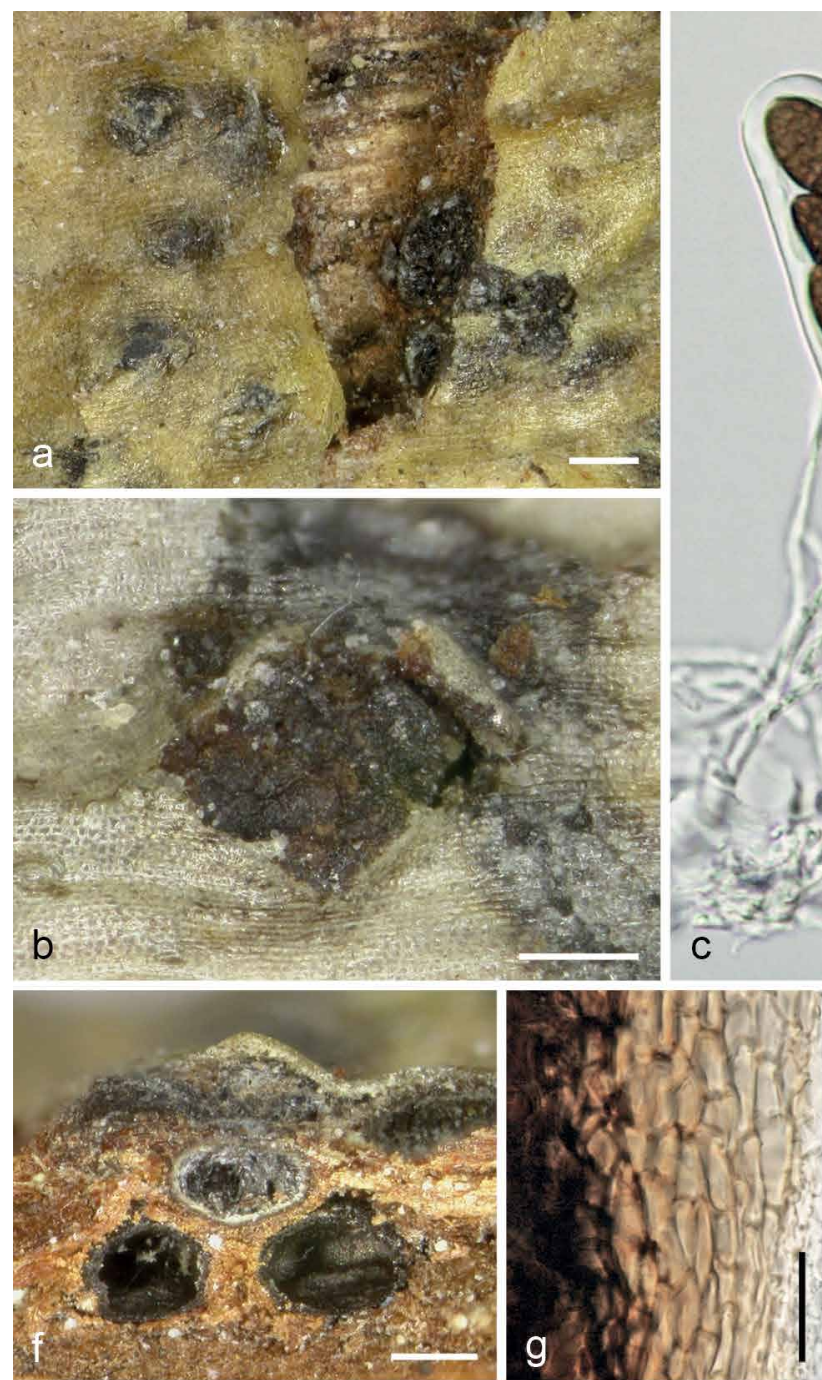

\section{g}
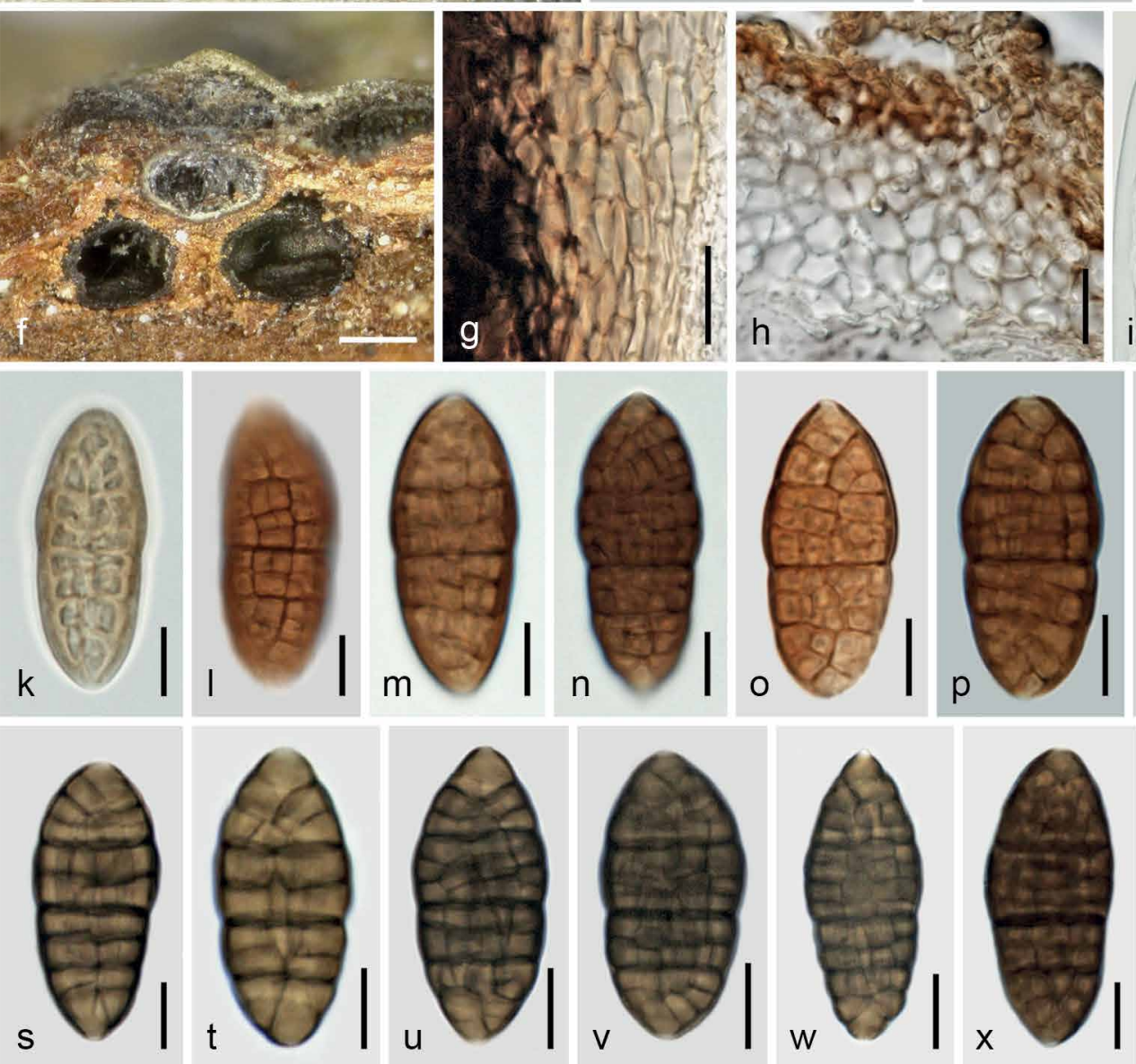
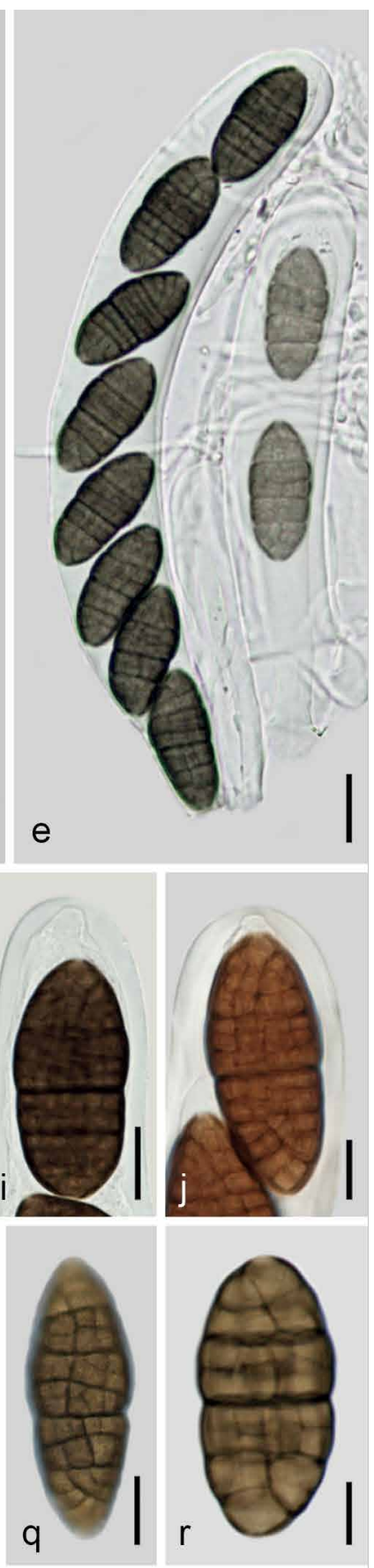

Fig. 12 Parafenestella faberi. a-b. Ascomata in face view (with superficial subiculum in b); c-e. asci; f. ascoma above Cytospora (Valsa) ascomata in vertical section; $\mathrm{g}-\mathrm{h}$. peridium in vertical section ( $\mathrm{g}$. from side; $\mathrm{h}$. from top); $\mathrm{i}-\mathrm{j}$. ascus apices; $\mathrm{k}-\mathrm{z}$. ascospores (k. immature; l, q. surface view) (e, q-w, y-z. in $3 \%$ $\mathrm{KOH}$; h, o. in lactoglycerol (from slides prepared by R. Phookamsak). a, c-d, f, h-i, o, q-y. lectotype GZU; b, e, g, j-n, p, z. WU 37022. - Scale bars: a-b, $f=200 \mu \mathrm{m} ; \mathrm{c}-\mathrm{e}, \mathrm{g}-\mathrm{h}=15 \mu \mathrm{m} ; \mathrm{i}, \mathrm{q}, \mathrm{u}-\mathrm{w}, \mathrm{y}-\mathrm{z}=10 \mu \mathrm{m} ; \mathrm{j}-\mathrm{p}, \mathrm{r}-\mathrm{t}, \mathrm{x}=7 \mu \mathrm{m}$. 
fungus Agyriella nitida as black gelatinous drops producing masses of cylindrical to allantoid, 1-celled hyaline conidia on ampulliform phialides, a Cytospora (Valsa morph) sp. and a Diplodia sp. No sexual morph matching C. occulta was found. Fuckel (1870) interpreted the Agyriella as asexual morph of his C. occulta. For comparison with other Parafenestella spp. on Rosaceae see notes under $P$. rosacearum.

Parafenestella faberi (J. Kunze) Jaklitsch \& Voglmayr, comb. nov. - MB829750; Fig. 12

Basionym. Fenestella faberi J. Kunze, Fung. Sel. Exs., Cent. 3: no. 263. 1879.

Synonyms. Fenestella mackenziei Wanas. et al., Mycosphere 8: 407 $2017 b$.

Parafenestella mackenziei (Wanas. et al.) Jaklitsch \& Voglmayr, in Jaklitsch et al., Stud. Mycol. 90: 109. 2018.

Lectotype of Fenestella faberi, here designated. Germany, SachsenAnhalt, Mansfeld-Südharz, Eisleben, Oberrißdorf, on dead corticated sticks of Rosa canina, Sept. 1878, J. Kunze (GZU, Inv No. 226, Digi Bota ID 365656; Joannes Kunze, Fungi Selecti exsiccati, ex museo botanico berolinensi; as Thyridium faberi J. Kunze, nom. nud.; MBT385688). No type material is extant in $\mathrm{B}$, therefore the material in $\mathrm{GZU}$, which was originally received from $\mathrm{B}$, may be the only available type specimen.

Ascomata (240-)300-450(-480) $\mu \mathrm{m}(\mathrm{n}=14)$ diam, subglobose to pyriform or subconical, black, tightly or loosely aggregated in small numbers in more or less valsoid configuration below blackened epidermis on inner bark or among ostiolar necks of Cytospora (Valsa) sp., partly erumpent through bark fissures, surrounded and connected by hyaline to brown, thickwalled, $2-4.5 \mu \mathrm{m}$ wide subicular hyphae; sometimes subiculum also forming brown discs c. 0.2-1 mm diam at the bark surface. Ostiolar areas 50-180 $\mu \mathrm{m}$ diam, inconspicuous, appearing as black dots or blunt black papillae. Peridium 15-70 $\mu \mathrm{m}$ thick, thickest around the ostiole, pseudoparenchymatous, consisting of $(4-) 5.5-10.5(-14.5) \mu \mathrm{m}(\mathrm{n}=54)$ wide cells, outside thickwalled and very dark brown textura angularis with encrusted pigment, gradually paler to hyaline and thinner-walled to the inside, partly terminated at the inner side by a compressed layer of pale brown longish cells; cells more isodiametric at upper levels and sometimes vertically elongated at the sides; in $3 \%$ $\mathrm{KOH}$ turning dark olivaceous to dark brown. Hamathecium consisting of numerous $1-3 \mu \mathrm{m}$ wide, branched ?paraphyses. Asci $(110-) 135-180(-200) \times(15.5-) 18.5-23.5(-26) \mu \mathrm{m}(\mathrm{n}=22)$, cylindrical to oblong or narrowly clavate, bitunicate, fissitunicate, with a distinct ocular chamber, a short stipe and simple or knoblike base, containing 4-8 ascospores in uniseriate to partly biseriate arrangement. Ascospores (23.5-)28.5-36(-42) $\times$ $(11-) 12.5-16(-17.5) \mu \mathrm{m}, \mathrm{I} / \mathrm{w}(1.9-) 2.1-2.5(-2.8)(\mathrm{n}=103)$, ellipsoid, sometimes fusoid, with upper part broader than lower, first hyaline, with 1-4 main septa, turning pale or yellowish brown, eventually dark brown, reddish brown in herbarium material, with 7-12(-14) transverse and 1-3(-5) longitudinal septa, slightly constricted at the median to submedian primary septum; end cells broadly or narrowly rounded, concolorous except for a truncate to convex hyaline terminal part of their walls; in $3 \% \mathrm{KOH}$ turning olivaceous to grey-brown; surface slightly verruculose.

Other material examined. AUSTRIA, Osttirol, Prägraten am Großvenediger, Umbalfälle, grid square 8939/4, on Cytospora (Valsa) sp. on a branch of Rosa canina, soc. Diplodia sp., 28 Aug. 2000, W. Jaklitsch W.J. 1539 (WU 37022).

Notes - Although ascospore size of Parafenestella faberi is in the range of $P$. austriaca and $P$. rosacearum (see below), its ascospores are unique due to the hyaline terminal wall of the terminal cells and a uniform shape. Ascospore septa appear rather distant in surface view, but dense in sectional view due to strong superposition. Ascospore size varies slightly among ascomata and specimens. We found the largest ascospores in the isotype, and they were even up to $34.7 \times 12.4 \mu \mathrm{m}$ in the slides prepared by R. Phookamsak. We synonymise $P$. mackenziei with $P$. faberi here, as we do not see a difference between them. The authors did not compare their new species with Fenestella faberi, although the latter was redescribed by Phookamsak \& Hyde (2015); in illustrations of Wanasinghe et al. (2017b) up to 12 transverse septa including incomplete ones are discernible. We give only a morphological account of this species here, as our material was not cultured and sequenced.

\section{Parafenestella germanica Jaklitsch \& Voglmayr, sp. nov. - MycoBank MB829751; Fig. 13}

Etymology. For its occurrence in Germany.

Holotype. Germany, Baden-Württemberg, Hornberg, Am Rubersbach, on Diaporthe decedens on a branch of Corylus avellana, soc. ?Cosmospora sp. and a dothideomycete with minute muriform spores, 18 Feb. 2018, K. Pätzold, comm. B. Wergen (WU 37017; ex-type culture CBS 145267 = C307).

Ascomata (195-)230-450(-570) $\mu \mathrm{m}(\mathrm{n}=12)$ diam, globose to subglobose, laterally collapsing from above, black, solitary or in small groups on inner bark or on the ostiolar level of old Diaporthe decedens, individually surrounded and connected by hyaline to dark brown, thick-walled, $1.5-6.5 \mu \mathrm{m}$ wide subicular hyphae with often swollen and sometimes forked attachment cells, near the ostiole often short with rounded ends (blunt setae). Ostiolar areas c. 60-160 $\mu \mathrm{m}$ diam, indistinct or slightly papillate, rounded, black, sometimes convergent in clustered ascomata. Peridium 10-60 $\mu \mathrm{m}$ thick, pseudoparenchymatous, consisting of $(4-) 5.5-10.5(-13.5) \mu \mathrm{m}(\mathrm{n}=32)$ wide cells, outside thick-walled and dark brown, paler to hyaline and thinnerwalled to the inside. Hamathecium consisting of numerous 1-3 $\mu \mathrm{m}$ wide, branched ?paraphyses; in $3 \% \mathrm{KOH}$ swelling to c. $6 \mu \mathrm{m}$ when old. Asci (128-)140-173(-193) × (17-)17.5-22(-24.5) $\mu \mathrm{m}(\mathrm{n}=25)$, cylindrical to oblong, bitunicate, fissitunicate, with a distinct ocular chamber, a short stipe and simple or knob-like base, containing 2-8 ascospores in (obliquely or overlapping) uniseriate arrangement. Ascospores (25.5-)29-39.5(-47) $\times(11-) 13-16.5(-19) \mu \mathrm{m}, \mathrm{I} / \mathrm{w}(1.9-) 2.1-2.5(-2.7)(\mathrm{n}=70)$, ellipsoid to broadly fusoid, symmetric, with the upper part often broader, first hyaline, with 1-3 main septa, more or less constricted at the median or slightly eccentric primary septum, turning yellow to yellow-brown and finally dark brown when mature, with often broadly rounded, paler to hyaline end cells, sometimes larger terminal parts paler than the middle, with (8-) $9-13(-15)$ transverse and 3-6 longitudinal septa; in $3 \% \mathrm{KOH}$ turning dark to blackish brown, end cells remaining hyaline.

Culture characteristics and asexual morph in culture - Colony radius on $\mathrm{CMD}$ at $22{ }^{\circ} \mathrm{C}$ in the dark up to $10 \mathrm{~mm}$ after $1 \mathrm{wk}, 18 \mathrm{~mm}$ after $2 \mathrm{wk}, 25 \mathrm{~mm}$ after $3 \mathrm{wk}$; colony first hyaline to whitish, dense, turning olivaceous, later greyish brownish due to a thick mat of aerial hyphae, surface and reverse becoming zonate; reverse dull grey to dark greyish olivaceous; odour indistinct. Pycnidia appearing after $4 \mathrm{~d}$, immersed to erumpent, c. $70-200 \mu \mathrm{m}$ diam, more or less globose, first hyaline, turning olivaceous to black, with whitish conidial drops. Peridium thin, pseudoparenchymatous, olivaceous. Phialides (3.2-)4.7-7.5(-9) × (1.7-)2-3(-4) $\mu \mathrm{m}(\mathrm{n}=30)$, sessile, subglobose to lageniform. Conidia (3.2-)3.5-4.3(-4.7) $\times(1.1-)$ $1.2-1.4(-1.6) \mu \mathrm{m}, \mathrm{I} / \mathrm{w}(2.5-) 2.7-3.4(-3.8)(\mathrm{n}=50)$, oblong to ellipsoid, 1-celled, hyaline, with 1-2 minute drops, smooth; also produced on pegs present below phialides. After a few transfers no pycnidia formed.

Habitat - On Diaporthe decedens on Corylus avellana.

Distribution - Central Europe (Germany), only known from the type locality.

Notes - Parafenestella germanica is phylogenetically closely related to $P$. pseudoplatani but has distinctly larger ascospores than the latter species. 

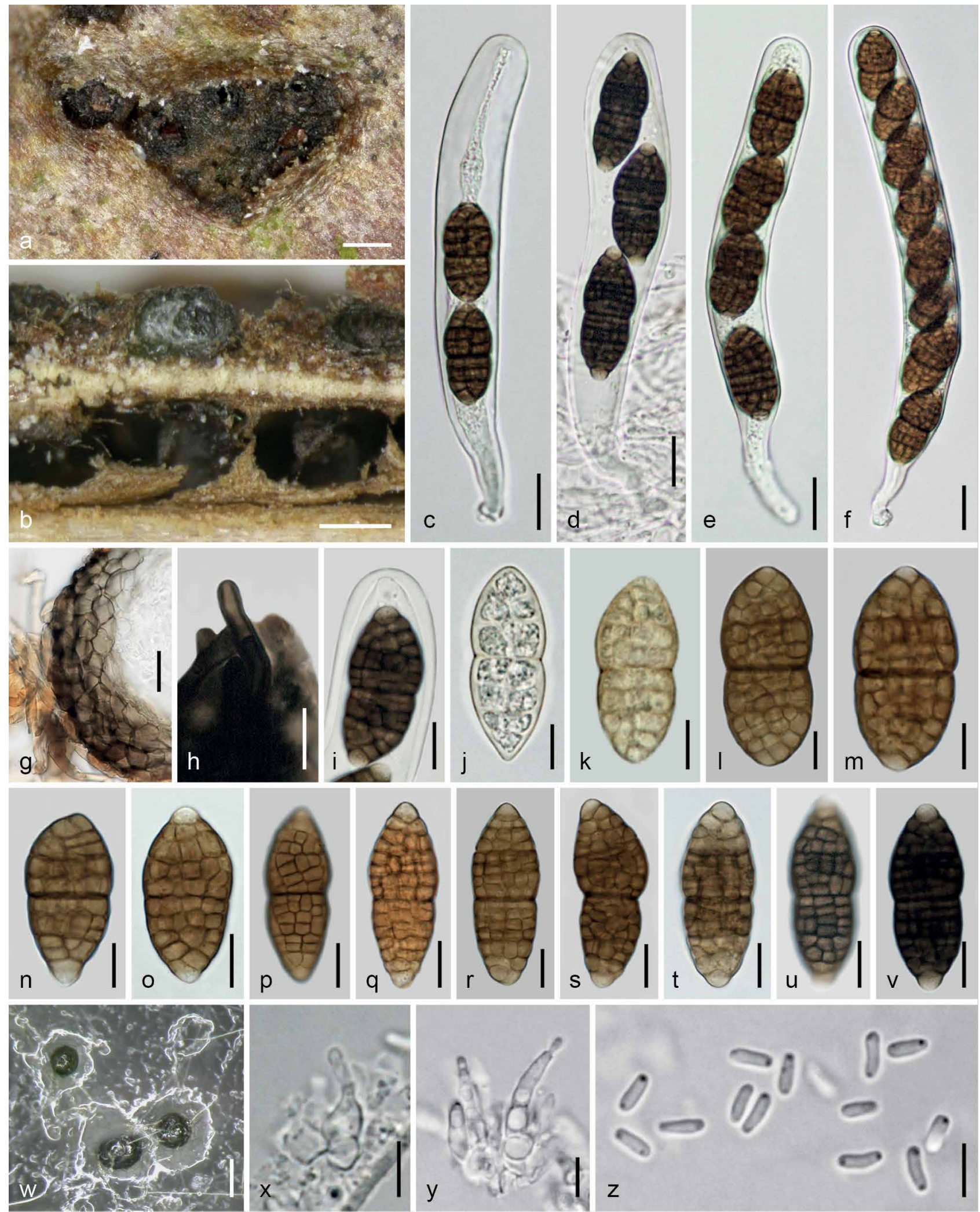

Fig. 13 Parafenestella germanica. a-v. Sexual morph (WU 37017). a. Ascomata and subiculum in face view; b. ascoma above Diaporthe ascomata in vertical section; c-f. asci (2-, 3-, 4- and 8-spored); g. peridium in vertical section; h. seta-like subicular hypha; i. ascus apex; j-v. ascospores (j-k. immature); w-z. asexual morph in culture (CBS 145267 (C307) from CMD at $22^{\circ} \mathrm{C}$ ); w. pycnidia; $\mathrm{x}-\mathrm{y}$. phialides; $\mathrm{z}$. conidia (d, h-i, u-v. in $3 \%$ KOH). $-\mathrm{Scale}$ bars: a-b, $w=150 \mu \mathrm{m} ; \mathrm{c}-\mathrm{g}=15 \mu \mathrm{m} ; \mathrm{h}-\mathrm{i}, \mathrm{o}-\mathrm{v}=10 \mu \mathrm{m} ; \mathrm{j}-\mathrm{n}=7 \mu \mathrm{m} ; \mathrm{x}-\mathrm{z}=5 \mu \mathrm{m}$.

Parafenestella parasalicum Jaklitsch \& Voglmayr, sp. nov. MycoBank MB829752, Fig. 14

Etymology. Para = at, near; the epithet refers to the close phylogenetic relationship with $P$. salicum.

Holotype. AustriA, Niederösterreich, Marchauen, Drösing, village area, on branch of Salix cinerea, on/soc. Cytospora (Valsa) sp., 7 Apr. 2018, H. Voglmayr (WU 37006; ex-type culture CBS 145271 = C318).
Ascomata 270-400 $\mu \mathrm{m}$ diam, globose, subglobose or pyriform, black, immersed in bark in the ostiolar region of Cytospora ( Valsa morph) or on inner bark, scattered, in valsoid configuration or in rows in small numbers, forming groups $0.5-1.7 \mathrm{~mm}$ diam, individually surrounded or connected by pale to dark brown, thick-walled, 1.5-6 $\mu \mathrm{m}$ wide subicular hyphae, the latter widened up to $10 \mu \mathrm{m}$ at the connection to the peridium; incon- 
spicuous at the bark surface, becoming visible in fissures. Ostiolar areas $(70-) 75-138(-160) \mu \mathrm{m}(\mathrm{n}=10)$ diam, flattened, convex or slightly papillate, shiny black, often mixed with minute pycnidia. Peridium 15-50 $\mu$ m thick, pseudoparenchymatous, consisting of isodiametric cells $(3.5-) 5.5-11(-14) \mu \mathrm{m}(\mathrm{n}=30)$ diam, outside thick-walled and very dark brown, paler brown to hyaline and thinner-walled toward the inner side and there also with some brownish compressed elongate cells; darkening in $3 \% \mathrm{KOH}$. Hamathecium consisting of numerous, 1-4 wide, branched ?paraphyses. Asci (176-)185-219(-239) $\times$ $(20-) 22-27(-30) \mu \mathrm{m}(\mathrm{n}=12)$, cylindrical to oblong, bitunicate, fissitunicate, with an ocular chamber, a short stipe and simple or knob-like base, containing 4-8 ascospores in (overlapping, obliquely) uniseriate to partly biseriate arrangement. Asco-
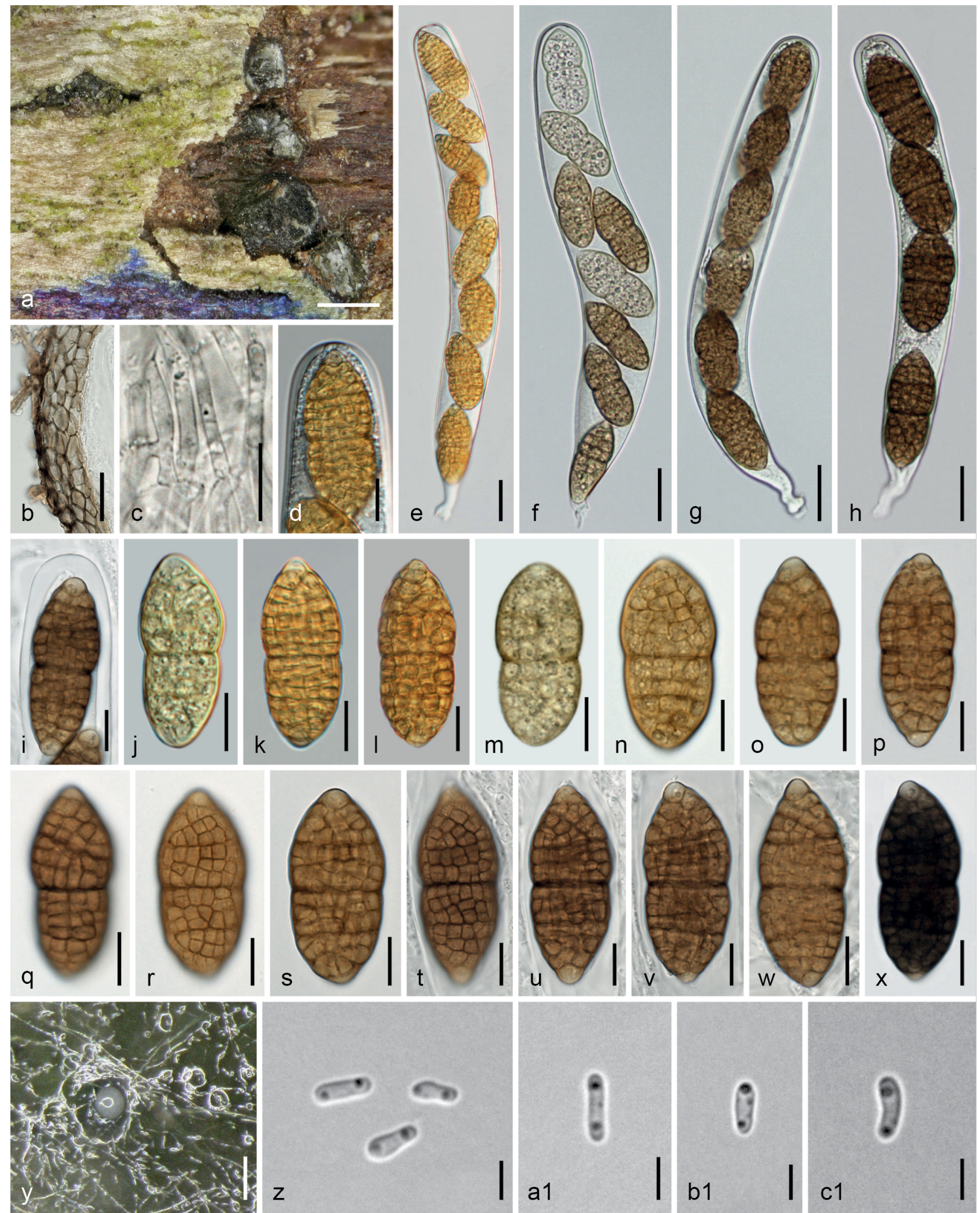

Fig. 14 Parafenestella parasalicum. a-x. Sexual morph (WU 37006). a. Ascomata in face view and in obliquely vertical section; b. peridium and subiculum hyphae in vertical section; c. hamathecium; d, i. ascus apices; e-h. asci (f. partially developed); $j-x$. ascospores (j, $m$. immature); $y-c 1$. asexual morph in culture (CBS 145271 (C318) from CMD at $22{ }^{\circ} \mathrm{C}$ ); y. pycnidia and conidial drops; $z-c 1$. conidia; $d-e, j-I$. from fresh material; $x$. in $3 \% \mathrm{KOH}$. - Scale bars: $\mathrm{a}=300 \mu \mathrm{m} ; \mathrm{b}, \mathrm{e}-\mathrm{h}=20 \mu \mathrm{m} ; \mathrm{c}-\mathrm{d}, \mathrm{i}-\mathrm{x}=10 \mu \mathrm{m} ; \mathrm{y}=100 \mu \mathrm{m} ; \mathrm{z}-\mathrm{c} 1=3 \mu \mathrm{m}$. 
spores (33.5-)36-44(-49.5) × (14.5-)15.8-19.3(-22.2) $\mu \mathrm{m}$, I/w (2-)2.1-2.4(-2.6) ( $n=44)$, fusoid or ellipsoid, first hyaline and 2-celled, developing 2 additional main septa, turning yellowish to yellow-brown and finally dark brown and eventually with 11-16 distinct and densely inserted transverse and 3-5 longitudinal septa; constricted at the primary septum, with the upper part usually broader and often longer than the lower; ends usually broadly rounded, concolorous, sometimes papillate and paler to hyaline, smooth, containing numerous minute droplets; in $3 \% \mathrm{KOH}$ turning dark to blackish brown.

Culture characteristics and asexual morph in culture - Colony radius on $\mathrm{CMD}$ at $22{ }^{\circ} \mathrm{C}$ in the dark $7-8 \mathrm{~mm}$ after $1 \mathrm{wk}$, $22 \mathrm{~mm}$ after $22 \mathrm{~d}$; colony first pale to medium grey, turning dark olivaceous grey, centre black; aerial hyphae long, white, forming a loose, later dense and thick mesh above the colony; reverse dark grey to black; odour indistinct. Pycnidia c. 45-100 $\mu \mathrm{m}$ diam, (sub-)globose, papillate, first appearing after 3-4 d, hyaline, turning dark olivaceous, mostly immersed, spreading from the centre, solitary or in firm small packs, with whitish turbid conidial drops. Peridium thin, pseudoparenchymatous, olivaceous, surrounded by olivaceous, partly submoniliform hyphae. Phialides (4-)4.2-6.2(-7) × (1.8-)2.2-3.5(-4) $\mu \mathrm{m}(\mathrm{n}=16)$, sessile, varying from subglobose over ampulliform or lageniform to subulate. Conidia (3.3-)3.6-4.4(-4.8) × (1-)1.1-1.5(-1.8) $\mu \mathrm{m}, \mathrm{I} / \mathrm{w}(2.2-) 2.6-3.4(-4.1)(\mathrm{n}=24)$, cylindrical to allantoid, less commonly narrowly ellipsoid, 1 -celled, hyaline with 2 small drops, smooth.

Habitat - On both morphs of a Cytospora (Valsa) sp. on Salix cinerea.

Distribution - Central Europe (Austria), only known from the type locality.

Notes - Parafenestella parasalicum is phylogenetically and morphologically close to $P$. salicum, but differs from the latter by larger ascospores.
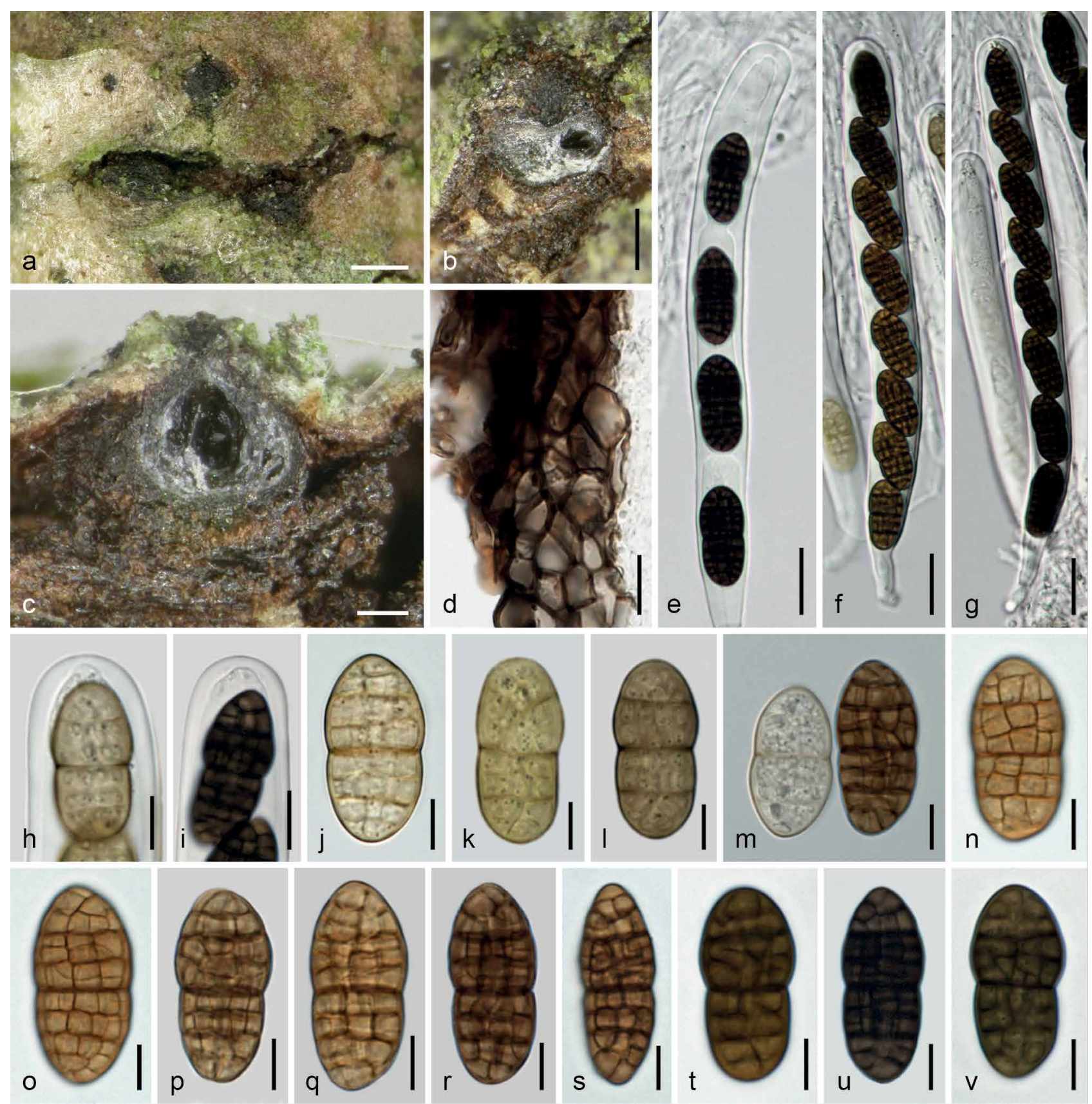

Fig. 15 Parafenestella pseudosalicis (WU 37016/CBS 145264 (C301)). a. Ascomata in bark fissures; b. apically depressed ascoma in oblique face view and in vertical section; c. ascoma in vertical section; d. peridium in vertical section; e-g. asci (e. 4-spored, spore part); $h-i$. ascus apices (h. immature); $j-v$. ascospores (j-I. immature; $m$. immature and mature mixed) $(e-i, k-I, t-v$. in $3 \% \mathrm{KOH}) .-$ Scale bars: $a=300 \mu \mathrm{m} ; b=200 \mu \mathrm{m} ; \mathrm{c}=100 \mu \mathrm{m} ; \mathrm{d}, \mathrm{i}=10 \mu \mathrm{m}$; $\mathrm{e}-\mathrm{g}=20 \mu \mathrm{m} ; \mathrm{h}, \mathrm{j}-\mathrm{v}=7 \mu \mathrm{m}$. 
Parafenestella pseudosalicis Jaklitsch \& Voglmayr, sp. nov. — MycoBank MB829753; Fig. 15

Etymology. Pseudo = false; the epithet denotes phylogenetic distinctness from $P$. salicis despite morphological similarity.

Holotype. UKRAINE, Ivano-Frankivsk region, Kosiv district, National Nature Park 'Hutsulshchyna' (Carpathians), on twigs of Salix cf. alba, soc. Cytospora sp., cf. Keissleriella sp., 5 Aug. 2017, A. Akulov (WU 37016; ex-type culture CBS $145264=$ C301)

Ascomata (270-)300-400 (-420) $\mu \mathrm{m}(\mathrm{n}=11)$ diam, subglobose to subpyriform, solitary or loosely or tightly aggregated in small numbers, immersed in bark or on ascomata of an effete perithecial fungus, often with concave apex, individually surrounded or connected by rather scant subhyaline to dark brown, thick-walled, $2-5.5 \mu \mathrm{m}$ wide subicular hyphae. Ostiolar areas $(53-) 60-116(-142) \mu \mathrm{m}(\mathrm{n}=10)$ diam, indistinct and inconspicuous, concave or papillate, black. Peridium 15-55 $\mu \mathrm{m}$ thick, pseudoparenchymatous, consisting of isodiametric cells (3.5-)4-8(-12) $\mu \mathrm{m}(\mathrm{n}=32)$ diam, outside thick-walled and dark brown, slightly paler and thinner-walled toward the inner side; darkening in $3 \% \mathrm{KOH}$. Hamathecium consisting of numerous, 1-4 wide, branched ?paraphyses. Asci (180-)186-215(-220) $\times(17-) 17.5-19(-19.5) \mu \mathrm{m}(\mathrm{n}=10)$, cylindrical to oblong, bitunicate, fissitunicate, with an ocular chamber, a short stipe and simple or knob-like base, containing 4-8 ascospores in uniseriate arrangement. Ascospores (23-)25-29(-32) $\times(11-)$ 12-14(-15) $\mu \mathrm{m}, \mathrm{I} / \mathrm{w}(1.9-) 2-2.3(-2.7)(\mathrm{n}=41)$, ellipsoid, first hyaline to yellowish, with 1-3 main septa, turning yellow-brown to dark brown, developing 7-10(-11) transverse and 2-4 longitudinal septa, distinct in surface view, in section difficult to count due to oblique superposition; constricted at the median primary septum, upper part often wider, ends concolorous, wall smooth, contents with minute guttules; in $3 \% \mathrm{KOH}$ turning very dark to blackish brown, yellow-green to greyish brown when immature.

Culture characteristics and asexual morph in culture - Colony radius on $\mathrm{CMD}$ at $22^{\circ} \mathrm{C}$ in the dark $6-7 \mathrm{~mm}$ after $1 \mathrm{wk}$, 15-16 mm after $2 \mathrm{wk}$; colony first hyaline to whitish, thick, dense, turning olivaceous from the centre, becoming grey to greyish brown due to a dense whitish to greyish villose mat of aerial hyphae; reverse dark grey to black; odour indistinct. No asexual morph detected.

Habitat - Associated with a perithecial fungus (probably Cytospora, Valsa morph) on Salix cf. alba.

Distribution - Europe, only known from the type locality in Ukraine.

Notes - Parafenestella pseudosalicis is morphologically similar to $P$. salicis, but differs from that species by a more regular, symmetric ascospore shape and more longitudinal septa being visible in surface view. Also, colonies on CMD tend to be more distinctly brown than with other species from Salix, which are more grey, and no asexual morph was produced in culture. However, as the species is based on a single species, further material would be necessary to evaluate its natural variation.

\section{Parafenestella rosacearum Jaklitsch \& Voglmayr, sp. nov. - MycoBank MB829754; Fig. 16}

Etymology. For its occurrence on various species of Rosaceae.

Holotype. AustrIA, Vienna, 22nd district, Spargelfeldstraße, on ?Diaporthe sp. on a branch of Pyracantha coccinea, soc. Diplodia sp., 25 Jan. 2018, R. Moosbeckhofer, comm. B. Wergen (WU 37010; ex-type culture CBS $145268=\mathrm{C} 309)$

Ascomata (270-)285-432(-510) $\mu \mathrm{m}(\mathrm{n}=42)$ diam, globose, subglobose to subpyriform, dark brown to black, immersed on often blackened inner bark or at the ostiolar level of Cytospora spp. or other perithecial fungi, scattered or in small groups, erumpent through bark fissures, laterally and basally loosely or tightly connected by hyaline to pale brown, less commonly dark brown, thick-walled, 2-5 $\mu \mathrm{m}$ wide subicular hyphae. Ostiolar areas $(53-) 73-125(-150) \mu \mathrm{m}(\mathrm{n}=47)$ diam, inconspicuous or papillate to short-cylindrical, sometimes depressed when immature, sometimes mixed with slender ostiolar necks of the host or often by pycnidia of its presumed asexual morph. Peridium 15-50 $\mu \mathrm{m}$ thick, pseudoparenchymatous, consisting of isodiametric cells $(2.7-) 4-8(-12) \mu \mathrm{m}(\mathrm{n}=30)$ diam, outside thick-walled and dark brown, paler to hyaline and thinner-walled to the inside; darkening in $3 \% \mathrm{KOH}$. Hamathecium consisting of numerous $1-3$, basally to $5 \mu \mathrm{m}$ wide branched paraphyses with free ends. Asci (150-)181-240(-290) ×(17-)19-22(-24) $\mu \mathrm{m}(\mathrm{n}=59)$, cylindrical to oblong, bitunicate, fissitunicate, with a distinct ocular chamber, a short, sometimes contorted stipe and simple or knob-like base, containing (2-)4-8 ascospores in uniseriate, rarely partly biseriate arrangement. Ascospores (23.3-)28-35(-44.5) × (11-)13.5-16.5(-19.5) $\mu \mathrm{m}$, I/w (1.7-)1.9-2.2(-2.6) ( $n=230)$, ellipsoid, symmetric to inequilateral, constricted at the more or less median primary septum, initially hyaline to yellowish, with 1-3 main septa, developing (7-)9-13(-15) transverse and 2-4(-5) longitudinal septa and turning yellow-brown, pale-, medium- to dark brown, ends broadly rounded and concolorous, less commonly narrowly rounded and slightly paler, surface appearing slightly verruculose; in $3 \% \mathrm{KOH}$ turning olivaceous when young, blackish brown when mature.

Culture characteristics and asexual morph in culture - Ascospores germinating simultaneously from many cells. Colony radius on CMD at $22^{\circ} \mathrm{C}$ in the dark $7-9 \mathrm{~mm}$ after $1 \mathrm{wk}$, up to $18 \mathrm{~mm}$ after $2 \mathrm{wk}, 35 \mathrm{~mm}$ after $5 \mathrm{wk}$; colony first hyaline, turning greyish olivaceous, dense, usually becoming thick and pale grey by a dense mesh of white aerial hyphae, long remaining pale greyish brownish olivaceous, finally darkening; reverse dark grey to black; odour indistinct. Pycnidia appearing after $4 \mathrm{~d}$, c. 80-200 $\mu \mathrm{m}$ diam, more or less globose, olivaceous, often numerous, aggregated, immersed in the agar and usually completely covered by a dense mat of aerial hyphae, with whitish conidial drops. Peridium thin, pseudoparenchymatous, brown to olivaceous, surrounded by submoniliform hyphae. Phialides $(2.7-) 4.7-8.2(-9.7) \times(2-) 2.5-4(-5.2) \mu m(n=25)$, sessile, varying from subglobose over ampulliform or lageniform to subulate; conidia also formed on lateral pegs below phialides. Conidia (3-)3.5-4.2(-4.8) × (1.1-)1.2-1.5(-1.7) $\mu \mathrm{m}, \mathrm{I} / \mathrm{w}(2-)$ $2.5-3.3(-4.1)(n=55)$, cylindrical or oblong, less commonly ellipsoid, 1-celled, hyaline, with 1-3 drops, smooth.

Habitat - Associated with Cytospora spp. and other perithecial fungi on various species of Rosaceae, recorded from Crataegus, Prunus, Pyracantha, Pyrus, Rosa and Sorbus aria. Distribution - Central Europe (Austria).

Othermaterials examined. AustRIA, Burgenland, Purbach, Purbacher Heide, on Cytospora sp. on a branch of Rosa canina, 24 Mar. 2018, H. Voglmayr (WU 37011; culture C315); Siegendorf, Königschüssel, on effete perithecia of ?Diaporthe sp. on Crataegus monogyna, 18 Sept. 2016, W. Jaklitsch \& H. Voglmayr (WU 37008; culture C269); Niederösterreich, Ulrichschlag, on Cytospora sp. on an attached branch of Pyrus communis, soc. Diplodia sp., 11 July 2015, W. Jaklitsch \& H. Voglmayr (WU 37007; culture C203); Oberösterreich, Schärding, Raab, Wetzlbach, on a branch of Prunus domestica, soc. diverse fungi including a Botryosphaeria sp., 2 Dec. 2017, H. Voglmayr (WU 37013; culture CBS 145272 = FP11); Steiermark, N Rein, Kaschsteig, on a branch of Sorbus aria, 30 June 2018, G. Friebes (WU 37023; culture C320); Ratten, Kirchenviertel, vlg. Kirchenberger, beim 'Dörrofen', on a branch of Pyrus communis, soc. Acanthostigma sp., 'Cucurbitaria acervata', a perithecioid fungus with yellow muriform ascospores and diverse pycnidia, 6 Jan. 2017, R. Moosbeckhofer (WU 37009; culture C283); Vienna, 21st district, at Marchfeldkanalweg near Felix Slavikstraße, on Cytospora sp. on a branch of Rosa canina, soc. Calosphaeria sp., Massarina sp., 8 Nov. 2015, W. Jaklitsch (WU 37012; culture FM1).

Notes - As deduced from the protologue, $P$. rosacearum may be what Saccardo (1884) termed Cucurbitaria delitescens 
* prunorum. However, we have not seen type material and a varietal name is not binding. Parafenestella rosacearum is a complex species. In spite of splitting into two or three groups in multigene analyses (see Fig. 1), we recognise a single species, because there are no morphological differences among those groups and particularly due to the following observations: tef1 sequences of C203 and C283 are identical and tef1 of C309 is nearly identical with them, whereas rpb2 sequences of C203, C315, FM1 and FP11 are virtually identical, while those of C269 and $\mathrm{C} 283$, which are identical, differ from the first group by $\mathrm{C}$. 20 nucleotides. This finding was verified by repetition of DNA amplifications and sequencing. Species of Parafenestella on Rosaceae, particularly on Rosa spp., are difficult to distinguish morphologically; ascospores of $P$. faberi are characteristic due
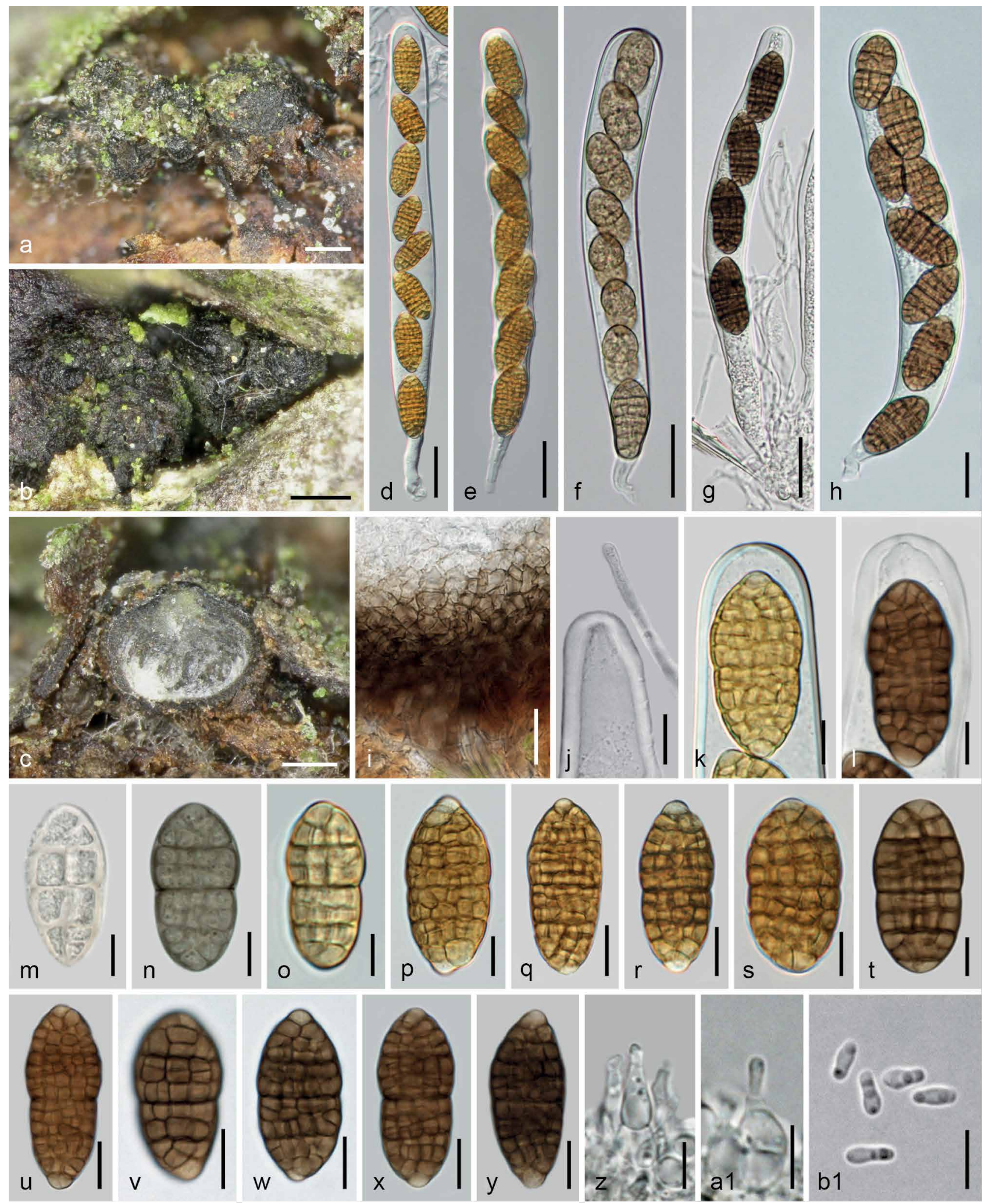

Fig. 16 Parafenestella rosacearum. a-y. Sexual morph. a-b. Ascomata in face view; c. ascoma in vertical section; d-h. asci (d-e. from fresh material; f. immature); i. basal peridium in vertical section; j. immature ascus apex and apically free paraphysis; $k-l$. ascus apices (k. from fresh material); $m-y$. ascospores (m-o. immature; p-s. from fresh material); $z-b 1$. asexual morph from CMD at $22^{\circ} \mathrm{C} ; \mathrm{z}-\mathrm{a} 1$. phialides; b1. conidia (j, n. in $\left.3 \% \mathrm{KOH}\right)$. a, c, f, $\mathrm{z}-\mathrm{b} 1$. WU $37010 /$ CBS 145268 (C309); b, d-e, i-k, p-s, y. WU 37013 (FP11); g, t, w. WU 37008 (C269); h, v. WU 37009 (C283); j, n. WU 37007 (C203); I, m, u, x. WU 37012 (FM1); o. WU 37011 (C315). - Scale bars: $a-b=250 \mu \mathrm{m} ; c=150 \mu \mathrm{m} ; \mathrm{d}-\mathrm{g}=25 \mu \mathrm{m} ; \mathrm{h}-\mathrm{i}=15 \mu \mathrm{m} ; \mathrm{j}, \mathrm{q}-\mathrm{r}, \mathrm{u}-\mathrm{y}=10 \mu \mathrm{m} ; \mathrm{k}-\mathrm{p}, \mathrm{s}-\mathrm{t}=7 \mu \mathrm{m} ; \mathrm{z}-\mathrm{b} 1=5 \mu \mathrm{m}$. 
to their often truncate hyaline terminus of the end cells, and $P$. austriaca differs from $P$. rosacearum by a rather invariable ascospore shape. In both of the latter species ascospore end cells are rounded, slightly projecting and may be only diffusely paler to hyaline.
Parafenestella salicis (Rehm) Jaklitsch \& Voglmayr, comb. nov. - MycoBank MB829755; Fig. 17

Basionym. Thyridium salicis Rehm, in Thümen, Beiträge zur Pilzflora Sibiriens IV, Bull. Soc. Imp. Naturalistes Moscou 55 (1-4): 218. 1880.

Synonyms. Fenestella salicis (Rehm) Sacc., Syll. Fung. (Abellini) 2: 330 1883.

Cucurbitaria marchica Kirschst., Ann. Mycol. 34: 186. 1936.
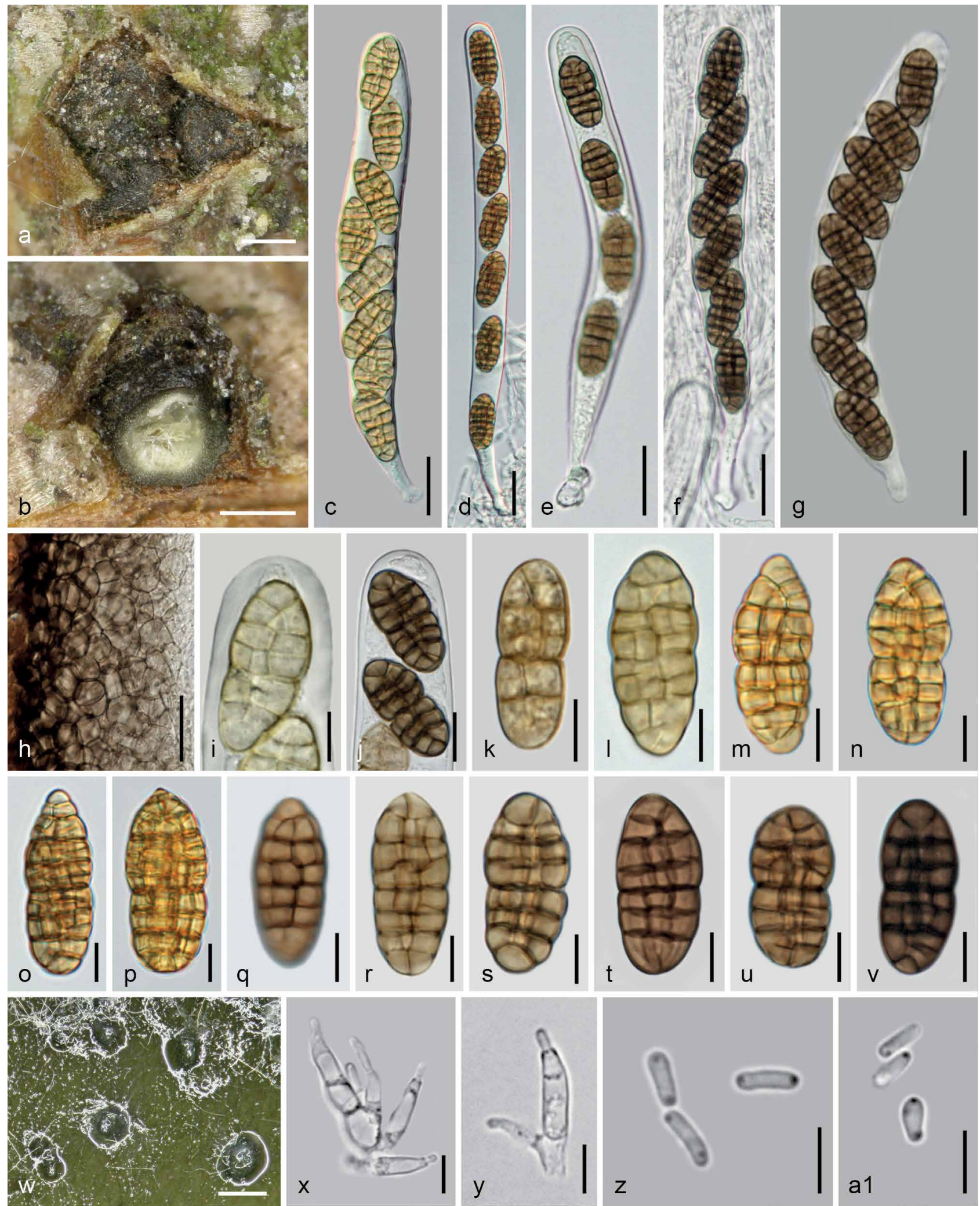

Fig. 17 Parafenestella salicis. a-v. Sexual morph. a. Ascomata in face view; b. ascoma in oblique view and in vertical section; c-g. asci (c. from fresh material); h. peridium in vertical section; $i-j$. ascus apices (i. young); $k-v$. ascospores ( $k-l$. immature / young; $m-p$. from fresh material); $w-a 1$. asexual morph from CMD at $22{ }^{\circ} \mathrm{C}$; w. pycnidia; $\mathrm{x}-\mathrm{y}$. phialides and short conidiophores; $\mathrm{z}-\mathrm{a} 1$. conidia (g, v. in $3 \% \mathrm{KOH}$ ). a-f, h, j-k, s, w-a1. WU $37002 / \mathrm{CBS} 145270$ (C313); g, r. K(M) 251618; i, I-n. WU 37003 (C311); o-p, u. WU 37001 (C303); q. part of WU 37015; t, v. C. marchica holotype B 700016516. - Scale bars: $a-b, w=250 \mu \mathrm{m} ; c-h=20 \mu \mathrm{m} ; \mathrm{i}, \mathrm{k}-\mathrm{v}=7 \mu \mathrm{m} ; \mathrm{j}=10 \mu \mathrm{m} ; \mathrm{x}-\mathrm{a} 1=5 \mu \mathrm{m}$. 
Typification. According to the herbarium curator of LE, Dr. Olga Morozova, comm. Dr. Eugene Popov, there is only a younger specimen of the original collector, N. Martianov, but not the type, extant in LE. Also, no type material has been found in other herbaria. Therefore we here propose a neotype for Thyridium salicis: AustRIA, Niederösterreich, Marchegg, on Cytospora (Valsa) sp. on branchlets of Salix alba, soc. a coniothyrium-like fungus, 17 Mar. 2018, H. Voglmayr (WU 37002; MBT385689; ex-neotype culture CBS $145270=$ C313).

Ascomata (255-)275-442(-510) $\mu \mathrm{m}(\mathrm{n}=20)$ diam, globose, subglobose to pyriform or subconical, black, immersed below the epidermis on inner bark or in the ostiolar region of Cytospora (Valsa) sp., scattered or tightly or loosely aggregated in valsoid or irregular configuration, partly erumpent through bark fissures, surrounded laterally and basally and connected by subhyaline to medium brown, thick-walled, $2-5 \mu \mathrm{m}$ wide subicular hyphae. Ostiolar areas $(35-) 55-118(-180) \mu \mathrm{m}(\mathrm{n}=22)$ diam, usually indistinct, sometimes papillate, rounded or apically flattened or compressed and furrowed, black. Peridium 20-80 $\mu \mathrm{m}$ thick, pseudoparenchymatous, consisting of $(4-) 6-13(-18) \mu \mathrm{m}$ $(n=30)$ wide cells, outside thick-walled and very dark brown, gradually paler and thinner-walled to the inside. Hamathecium consisting of numerous, $1-3.5 \mu \mathrm{m}$ wide, branched ?paraphyses; when old widened up to c. $6 \mu \mathrm{m}$ and submoniliform at their bases. Asci (131-)141-188(-220) ×(14.8-)16-19(-21.5) $\mu \mathrm{m}$ $(\mathrm{n}=33)$, cylindrical to oblong, bitunicate, fissitunicate, with a distinct ocular chamber, a short stipe and simple or knob-like base, containing (1-)4-8 ascospores in (obliquely) uniseriate to partly biseriate arrangement. Ascospores (20.5-)23-29(-34) $\times(10-) 11-13.5(-15) \mu \mathrm{m}, \mathrm{I} / \mathrm{w}(1.5-) 1.9-2.3(-2.7)(\mathrm{n}=152)$, ellipsoid to fusoid, slightly to distinctly constricted at the more or less median primary septum, often also at other septa, symmetric to inequilateral, first hyaline to yellowish, with 1-3 main septa, turning bright or golden yellow to yellow-brown (when fresh), eventually dark brown, with (5-6-)7-10(-11) transverse and (1-)2-3 longitudinal septa, the former often with oblique superposition in section, the latter often forming parallel lines; ends broadly rounded and concolorous, less commonly narrowly rounded and only rarely hyaline immediately before germination, smooth. Often tightly accompanied by the presumed asexual morph forming pycnidia with minute cylindrical to allantoid, 1-celled, hyaline conidia.

Culture characteristics and asexual morph in culture - Colony radius on $\mathrm{CMD}$ at $22{ }^{\circ} \mathrm{C}$ in the dark $9-11 \mathrm{~mm}$ after $1 \mathrm{wk}$, $22 \mathrm{~mm}$ after $2 \mathrm{wk}$; colony dense, first hyaline, turning olivaceous and later pale to dark grey owing to aerial hyphae; reverse dark grey to black; odour indistinct to sour. Pycnidia appearing after 3 d, c. 80-200 $\mu$ m diam, numerous, immersed, partially erumpent, scattered or tightly aggregated to confluent in small numbers, globose or subglobose, papillate, olivaceous to black, with whitish to greyish conidial drops, partly covered by aerial hyphae, surrounded by olivaceous to brown hyphae. Peridium thin, pseudoparenchymatous, olivaceous. Phialides $(4.3-) 5.3-9(-10.5) \times(1.8-) 2-3(-3.8) \mu \mathrm{m}(\mathrm{n}=22)$, subglobose to subcylindrical, sessile or formed on short conidiophores; conidia also formed on pegs. Conidia (3.2-)3.7-4.5(-5.2) $\times$ $(1-) 1.1-1.5(-1.7) \mu \mathrm{m}, \mathrm{I} / \mathrm{w}(2.1-) 2.7-3.6(-4.2)(\mathrm{n}=64)$, cylindrical to allantoid, sometimes narrowly ellipsoid, 1-celled, hyaline, with 1-2 subterminal drops, smooth.

Habitat - On both morphs of Cytospora (Valsa) $\mathrm{sp}(\mathrm{p})$. on Salix spp.

Distribution - Europe (Austria, Germany, UK), Russia, etc.

Other materials examined. AusTRIA, Niederösterreich, Orth, on Cytospora (Valsa) sp. on branchlets of Salix alba, soc. Diplodia sp., 3 Feb. 2018, H. Voglmayr (WU 37001; culture C303); same area, on Cytospora sp. on branches of Salix alba, soc. Coniothyrium sp., Parafenestella salicum (removed as WU 37004), 10 Mar. 2018, W. Jaklitsch \& H. Voglmayr (WU 37003). - GeRMANY, Westhavelland, Quermathen bei Großbehnitz, Löffelpfuhl, on branches of Salix cinerea, 4 Nov. 1935, W. Kirschstein (B 70 0016516; holotype of Cucurbitaria marchica). - UK, England, Kew, on twigs of Salix cinerea, apparently on Plagiostoma sp., May 1887, no collector given (K-M 251618).
Notes - Judging on the specimens we have seen, $P$. salicis is the most common species of the genus on Salix spp. and occurs often together with other Parafenestella species. Counting of ascospore septa in sectional view is particularly difficult in this species, due to conspicuous superposition; they differ from those of $P$. salicum and $P$. parasalicum in less and more widely spaced septa and from the latter also by size. Ascospores are often inequilateral and often slightly constricted at other than the primary septum, traits not seen with P. pseudosalicis. Like with other species, mature ascospores are often dark reddish brown in herbarium material.

Other species/names described on Salix: Cucurbitaria salicina was described from Salix fragilis and $S$. triandra with ascospores measuring $22 \times 9 \mu \mathrm{m}$ having $4-5$ transverse septa and 1 longitudinal septum. The holotype (Germany, Oestrich, L. Fuckel, G 00127757, ex Herbier Barbey-Boissier, Nassau's Flora. 6) does not contain a sexual morph but numerous pycnidia with camarosporium-like conidia and a Diplodia sp. Cucurbitaria cinerea, described from Salix aurita, is Discostroma corticola, according to Brockmann (1976). Cucurbitaria rubefaciens, described from Salix caprea, does not belong to the Cucurbitariaceae (unpublished results).

\section{Parafenestella salicum Jaklitsch \& Voglmayr, sp. nov. — Myco- Bank MB829756; Fig. 18}

Etymology. For its occurrence on species of Salix.

Holotype. AustrIA, Niederösterreich, Orth, on thin branches of Salix alba, soc. effete Cytospora sp., Massarina sp., Parafenestella salicis (removed as WU 37003) and effete Plagiostoma sp., 10 Mar. 2018, W. Jaklitsch \& H. Voglmayr (WU 37004; ex-type culture CBS 145269 = C311).

Ascomata (270-)280-375(-420) $\mu \mathrm{m}(\mathrm{n}=11)$ diam, globose, subglobose or pyriform, black, laterally collapsing, immersed in bark over a perithecial host fungus or firmly connected to the inner bark layers, scattered or aggregated in small numbers in valsoid groups, connected by subhyaline to dark brown, thick-walled, 1.5-5 $\mu \mathrm{m}$ wide subicular hyphae. Ostiolar areas 85-200 $\mu \mathrm{m}$ diam, inconspicuous at the bark surface, roundish to longish, black, often apically flattened, sometimes concave or papillate; sometimes accompanied by pycnidia of the putative asexual morph. Peridium 15-65 $\mu$ m thick, pseudoparenchymatous, consisting of $(3.5-) 6-10(-12.5) \mu \mathrm{m}(\mathrm{n}=40)$ wide cells, outside thick-walled and very dark brown and forming a narrow layer, gradually paler to hyaline and thinner-walled to the inside, terminated by a narrow layer of brownish compressed cells. Hamathecium consisting of numerous $1-3.5(-4) \mu \mathrm{m}$ wide, branched ?paraphyses. Asci (172-)181-228(-246) × (17.5-) $19.5-24(-28) \mu \mathrm{m}(\mathrm{n}=20)$, cylindrical, bitunicate, fissitunicate, with a distinct ocular chamber, a short stipe and simple or knob-like base, containing 6-8 ascospores in (overlapping) uniseriate arrangement. Ascospores (22.5-)27-33(-40) $\times$ (11-)12.5-16(-18) $\mu \mathrm{m}, \mathrm{I} / \mathrm{w}(1.7-) 1.9-2.3(-2.5)(\mathrm{n}=110)$, broadly ellipsoid to broadly fusoid with broadly rounded ends or one end narrowly rounded, upper part often slightly wider, not or slightly constricted at the median primary septum, first 2-celled and hyaline, turning golden yellow to golden brown, eventually dark brown or dark reddish brown, ends concolorous, only rarely slightly paler and sometimes slightly projecting, with 9-13(-14) transverse and 3-4 longitudinal septa; smooth. Presumed asexual morph forming pycnidia at the apices or sides of ascomata, c. 70-150 $\mu \mathrm{m}$ diam, more or less globose, with masses of oblong, allantoid to narrowly ellipsoid, 1-celled, hyaline conidia typically containing two drops.

Culture characteristics and asexual morph in culture - Ascospores germinating simultaneously from many cells. Colony radius on $\mathrm{CMD}$ at $22{ }^{\circ} \mathrm{C}$ in the dark $5-7 \mathrm{~mm}$ after $1 \mathrm{wk}, 16 \mathrm{~mm}$ after $2 \mathrm{wk}, 18 \mathrm{~mm}$ after $27 \mathrm{~d}$; colony pale brownish to pale grey- 
ish brown, covered by a dense and thick mat of aerial hyphae; reverse dark grey; odour indistinct to unpleasant. Pycnidia appearing after $3 \mathrm{~d}$, numerous, immersed, partially erumpent, 80-180 $\mu \mathrm{m}$ diam, solitary, in lines or tightly aggregated in small numbers, globose, subglobose or vertically elongated, papillate, greenish, olivaceous to black, with narrow periphy- ses in the ostiole; conidial drops whitish to greyish. Peridium thin, pseudoparenchymatous, an olivaceous textura angularis of $(6.5-) 8.5-14.5(-19) \mu \mathrm{m}(\mathrm{n}=30)$ wide cells; surrounded by submoniliform hyphae. Phialides (4-)4.5-6.2(-7.3) $\times$ $(1.5-) 1.8-3.5(-4.7) \mu \mathrm{m}(\mathrm{n}=20)$, sessile, subglobose, ampulliform, lageniform to subcylindrical. Conidia (3.3-)3.5-4(-4.5)
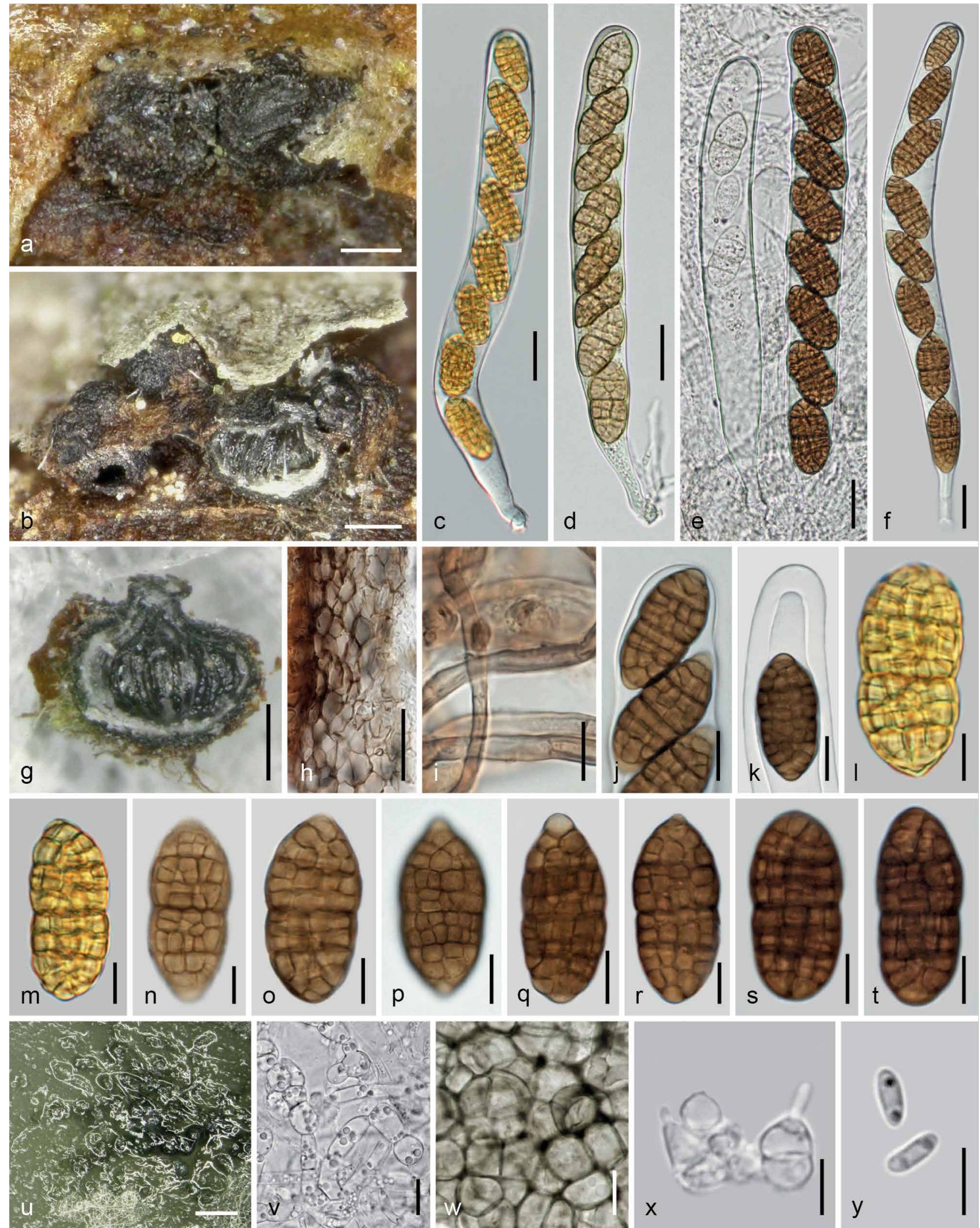

Fig. 18 Parafenestella salicum. a-t. Sexual morph. a. Ascomata in face view; b, g. ascomata in oblique view and in vertical section (detached in g); c-f. asci (c. from fresh material; d. young; e. early stage on the left side); h. peridium in vertical section; i. subicular hyphae; j-k. ascus apices; I-t. ascospores (I-m. from fresh material); $u-y$. asexual morph from $C M D$ at $22^{\circ} \mathrm{C}$; u. pycnidia; v. submoniliform hyphae; w. peridium in face view; $x$. phialides; $y$. conidia. a-g, i-r, u-y. WU 37004/CBS 145269 (C311); h, s-t. WU 37005. - Scale bars: a-b, g = $150 \mu \mathrm{m} ; \mathrm{c}-\mathrm{f}, \mathrm{h}=20 \mu \mathrm{m} ; \mathrm{i}-\mathrm{k}, \mathrm{p}-\mathrm{q}, \mathrm{v}-\mathrm{w}=10 \mu \mathrm{m} ; \mathrm{l}-\mathrm{o}, \mathrm{r}-\mathrm{t}=7 \mu \mathrm{m} ; \mathrm{u}=300$ $\mu \mathrm{m} ; \mathrm{x}-\mathrm{y}=5 \mu \mathrm{m}$. 
$\times(0.9-) 1.1-1.6(-2) \mu \mathrm{m}, \mathrm{I} / \mathrm{w}(1.9-) 2.4-3.4(-4.1)(\mathrm{n}=42)$, cylindrical to allantoid, sometimes nar-rowly ellipsoid, 1 -celled, hyaline, with 2 subterminal drops, smooth.

Habitat - On thin branches of Salix alba, presumably on both morphs of a Cytospora (Valsa) sp.

Distribution - Europe (Austria).
Other material examined. AusTRIA, Vienna, 22nd district, Lobau, Panozzalacke, grid square $7865 / 1$, on thin branches of Salix alba, soc. effete Cytospora sp., Keissleriella holmiorum, 8 Feb. 1997, W. Jaklitsch W.J. 1015 (WU 37005)

Notes - Parafenestella salicum differs from $P$. salicis by larger asci, larger, particularly broader ascospores with a larger number of septa. While phylogenetically closely related to
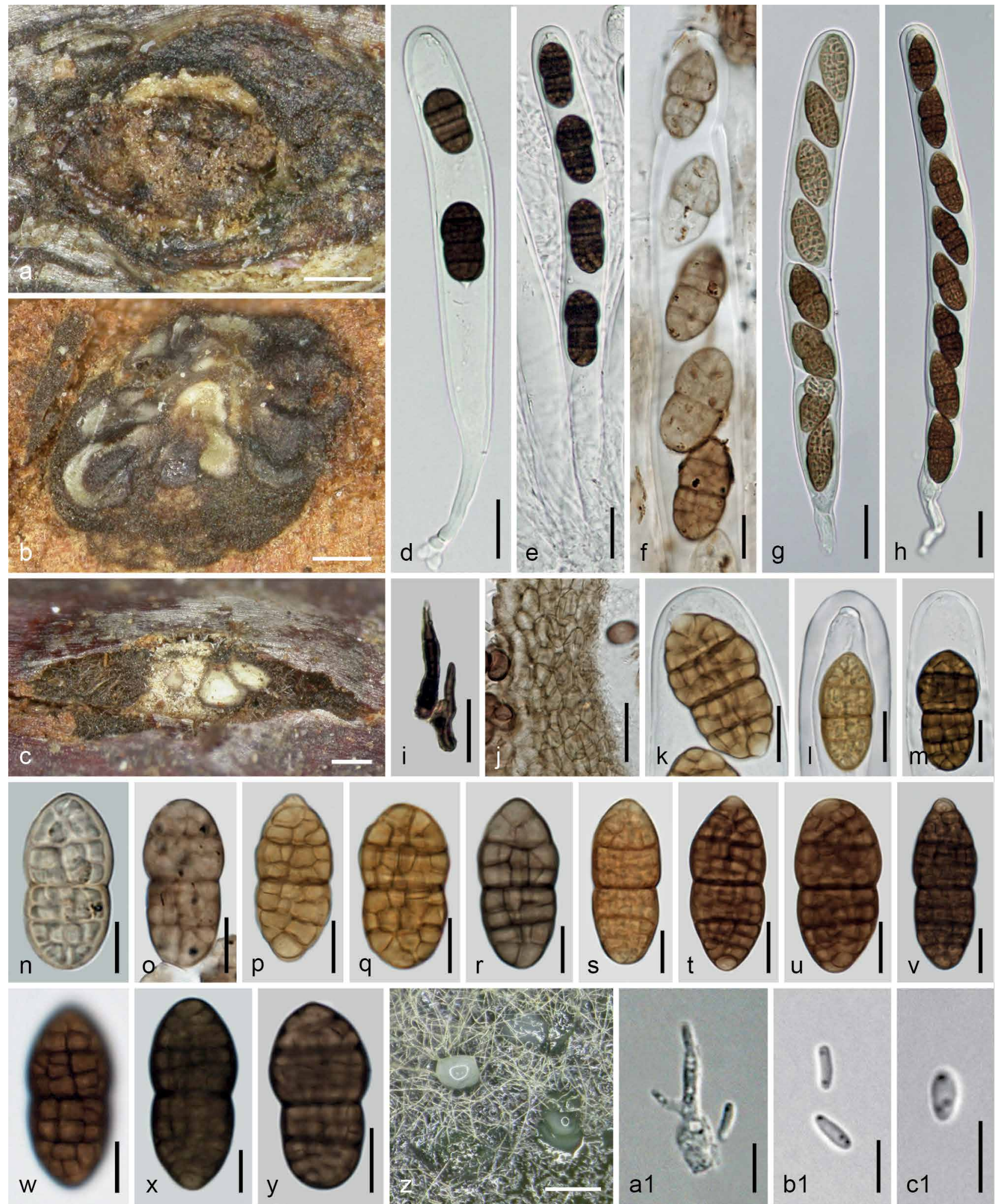

Fig. 19 Parafenestella tetratrupha. a-y. Sexual morph. a. Ascomata and subiculum in face view; b. cluster of ascomata in conidioma of Melanconis alni (grey patches at bottom and left are host conidia); c. young ascomata in conidioma of Melanconis alni; $d-h$. asci (f. upper part, partially developed, apically opening); i. ascomatal setae; j. peridium in vertical section (showing host conidia); $\mathrm{k}-\mathrm{m}$. ascus apices; $\mathrm{n}-\mathrm{y}$. ascospores ( $\mathrm{n}$. immature); $\mathrm{z}-\mathrm{c} 1$. asexual morph from $\mathrm{CMD}$ at $22{ }^{\circ} \mathrm{C}$; z. pycnidia and conidial drops; a1. phialide and basal peg; b1-c1. conidia (d-e, i-j, m, r, x-y. in $3 \% \mathrm{KOH}$ ). a, d-e, i, I-m, w, y. WU 37000 ; b, g-h, s-v, x. Valsa tetratrupha holotype K-M 251617; c, f, j, n-o. Fenestella minor holotype PC 0706652; k, p-r, z-c1. WU 36999/CBS 145266 (C304). - Scale bars: $a-c, z=200 \mu \mathrm{m} ; \mathrm{d}-\mathrm{e}, \mathrm{g}-\mathrm{j}=20 \mu \mathrm{m} ; \mathrm{f}, \mathrm{k}-\mathrm{m}, \mathrm{o}-\mathrm{q}, \mathrm{t}-\mathrm{v}, \mathrm{y}=10 \mu \mathrm{m} ; \mathrm{n}, \mathrm{r}-\mathrm{s}, \mathrm{w}-\mathrm{x}=7 \mu \mathrm{m} ; \mathrm{a} 1-\mathrm{c} 1=5 \mu \mathrm{m}$. 
P. parasalicum, $P$. salicum differs from that species by smaller ascospores, although some old aberrant ascospores may approach those of $P$. parasalicum in size. The fungal host of $P$. salicum is not unequivocally clear. As is usual in the Cucurbitariaceae, ascospores are more reddish brown in herbarium material.

\section{Parafenestella tetratrupha (Berk. \& Broome) Jaklitsch \&} Voglmayr, comb. nov. - MycoBank MB829757; Fig. 19

Basionym. Valsa tetratrupha Berk. \& Broome, Ann. Mag. Nat. Hist., ser. III, 3: 366. 1859.

Synonyms. Fenestella tetratrupha (Berk. \& Broome) Sacc., Syll. Fung (Abellini) 2: 326. 1883.

Fenestella minor Tul. \& C. Tul., Select. Fung. Carp. 2: 207. 1863.

Holotype. UK, England, North Somerset, Batheaston, on conidiomata of Melanconis alni on twigs of Alnus sp. (probably A. glutinosa), Feb. 1852, C.E. Broome (K-M 251617, as Fenestella minor written on the outer, Sphaeria tetratrupha on the inner label). Epitype of Fenestella minor and Valsa tetratrupha, here designated: AustRIA, Kärnten, St. Margareten im Rosental, village area, at the brook Tumpfi, on conidiomata of Melanconis alni on a branch of Alnus glutinosa, partly overgrown by Fusarium/Cosmospora (s.lat.) sp., 4 Feb. 2018, W. Jaklitsch (WU 36999; MBT385691, MBT385690; exepitype culture CBS $145266=$ C304)

Ascomata (240-)300-500(-630) $\mu \mathrm{m}(\mathrm{n}=31)$ diam, globose, subglobose or pyriform, immersed in the ostiolar region of $\mathrm{Me}$ lanconis alni conidiomata singly or in more or less valsoid groups with often convergent ostiolar necks, tightly or loosely aggregated in whitish to dark brown subiculum, forming pustules c. $0.5-2.3 \mathrm{~mm}$ depending on the size of the host, projecting up to $0.6 \mathrm{~mm}$ from the bark surface. Pustules pulvinate, causing small bumps in elevated bark, erumpent through fissures, outline circular, elliptic or elongate, surface obtuse, dark brown to black, often partly covered by brown subiculum consisting of subhyaline to dark brown, thick-walled, 1.5-6 $\mu \mathrm{m}$ wide hyphae, mixed with dark brown, pointed, thick-walled, up to 60 $\mu \mathrm{m}$ long and 2-6 $\mu \mathrm{m}$ wide setae on the ascomatal surface. Ostiolar areas $70-186(-270) \mu \mathrm{m}(\mathrm{n}=17)$ diam, inconspicuous or papillate, sometimes eccentric and convergent, rounded or flat and angular, brown to black, whitish inside, often mixed with shiny black ostiolar necks of the host. Peridium 15-100 $\mu \mathrm{m}$ thick, pseudoparenchymatous, consisting of isodiametric cells $(4-) 6-11(-13.5) \mu m(n=30)$ diam, outside moderately thick-walled and dark brown, paler and thinner-walled to the inside. Hamathecium consisting of numerous $0.5-3.5 \mu \mathrm{m}$ wide branched ?paraphyses. Asci (141-)154-229(-294) × (16.8-) $18.5-22.2(-26) \mu \mathrm{m}(\mathrm{n}=50)$, cylindrical to oblong, bitunicate, fissitunicate, with a truncate ocular chamber, a short stipe and simple or knob-like base, containing 2-8 ascospores in uniseriate arrangement. Ascospores (19-)26.5-33.5(-39) $\times$ $(10-) 13-16.5(-18) \mu \mathrm{m}, \mathrm{I} / \mathrm{w}(1.7-) 1.9-2.3(-2.8)(\mathrm{n}=120)$, ellipsoid with broadly rounded ends or upper end narrowly rounded, sometimes broadly fusoid, first hyaline, with 1-3 main septa, turning yellow to yellow- or pale brown and finally reddish brown to dark brown with concolorous, rarely paler ends and 8-14(-17) distinct transverse and 2-4 longitudinal septa; constricted at the median primary septum and upper part often slightly wider; surface finely verruculose; in $3 \% \mathrm{KOH}$ becoming dark olivaceous to blackish brown.

Culture characteristics and asexual morph in culture - Ascospores germinating simultaneously from many cells. Colony radius on CMD at $22^{\circ} \mathrm{C}$ in the dark $9 \mathrm{~mm}$ after $1 \mathrm{wk}, 27 \mathrm{~mm}$ after $24 \mathrm{~d}$; colony olivaceous, but in face view appearing pale grey to greyish brown due to a thick and dense mat of whitish aerial hyphae; reverse dark grey; odour indistinct. Pycnidia c. 100-200 $\mu \mathrm{m}$ diam, subglobose, olivaceous, completely covered by aerial hyphae, scattered, immersed, partly erumpent, with whitish conidial drops; spreading from the centre. Peridium thin, pseudoparenchymatous, olivaceous. Phialides (3.5-)4.5$6.7(-7.5) \times(1.7-) 2.2-4(-4.2) \mu \mathrm{m}(\mathrm{n}=21)$, sessile, varying from subglobose over ampulliform and lageniform to subulate; conidia also formed on lateral pegs. Conidia (3.2-)3.5-4.3(-6) $\times(0.9-) 1-1.2(-1.4) \mu \mathrm{m}, \mathrm{I} / \mathrm{w}(2.8-) 3.2-4.1(-4.7)(\mathrm{n}=50)$, cylindrical to allantoid, rarely narrowly ellipsoid, 1-celled, hyaline, with 2 small drops, smooth.

Habitat - On or in conidiomata of Melanconis alni on Alnus glutinosa.

Distribution - Europe (Austria, France, UK).

Other materials examined. AusTRIA, Kärnten, St. Margareten im Rosental, village area, at the brook Tumpfi, grid square $9452 / 4$, on conidiomata of Melanconis alni on a branch of Alnus glutinosa, 17 Dec. 1994, W. Jaklitsch W.J. 377 (WU 37000). - FRANCE, Chaville, on conidiomata of Melanconis alni on Alnus glutinosa, soc. Cytospora sp., Apr. 1860, L.-R. Tulasne (PC 0706652, holotype of Fenestella minor, donated to PC in 1873 as Sphaeria fenestrata deminuta in herb).

Notes - The fungal host of $P$. tetratrupha is clearly Melanconis alni, usually present as asexual morph and easily identifiable by the white central stromatic column and the brown conidia having a pale median band. Conidia of the host are present directly below ascomata in all studied specimens and usually adhere in masses to the peridium. The holotype of Fenestella minor has scant and mostly immature material, whereas the holotype of Valsa tetratrupha has well-developed ascomata with mostly 8-spored asci, although 4-spored asci are given in the protologue. The number of ascospores in the ascus depends much of the developmental condition of ascomata.

\section{Parafenestella vindobonensis Jaklitsch \& Voglmayr, sp. nov.} - MycoBank MB829758; Fig. 20

Etymology. For its occurrence in Vienna, Austria.

Holotype. AustriA, Vienna, 21st district, Wasserpark, on Cytospora sp. on Salix babylonica, soc. Massarina sp., Parafenestella salicis and a pycnidial fungus with fusoid, hyaline, 1-celled conidia, 27 Jan. 2018, W. Jaklitsch (WU 37015; ex-type culture CBS $145265=$ C302)

Ascomata (240-)308-425(-450) $\mu \mathrm{m}(\mathrm{n}=13)$ diam, globose, subglobose or pyriform, black, immersed in bark, partially erumpent, forming more or less valsoid groups in usually loose connection by hyaline to dark brown, thick-walled, 2-5 $\mu \mathrm{m}$ wide subicular hyphae or entirely covered by subiculum, sometimes tightly aggregated in small groups on inner bark and on conidiomata and pseudostromata of a Cytospora sp., partly blackening inner bark. Ostiolar areas (70-)75-145(-160) $\mu \mathrm{m}$ $(n=11)$ diam, indistinct or papillate, black, rounded or angular in section. Peridium 15-65(-80) $\mu \mathrm{m}$ thick, pseudoparenchymatous, consisting of $(4-) 5-10(-12) \mu \mathrm{m}(n=40)$ wide cells, outside thick-walled and dark brown, paler and slightly thinnerwalled to the inside. Hamathecium consisting of numerous 1-3 $\mu \mathrm{m}$ wide, branched paraphyses with free ends. Asci $(162-) 179-214(-228) \times(12.5-) 13.5-15.5(-16) \mu \mathrm{m}(\mathrm{n}=25)$, cylindrical, bitunicate, fissitunicate, with a distinct ocular chamber, a short stipe and simple or knob-like base, containing 4-8 ascospores in uniseriate arrangement. Ascospores (20-)24.5$30.5(-37.5) \times(8.5-) 9.5-11(-13) \mu \mathrm{m}, \mathrm{I} / \mathrm{w}(2-) 2.4-2.9(-3.4)$ $(\mathrm{n}=85)$, oblong, fusoid or narrowly ellipsoid, first hyaline, with 1-6 main septa, turning yellowish, pale, yellow- to golden or medium brown with concolorous or slightly paler ends, thick-walled, when mature with 7-9(-11) thick transverse and $1-2(-3)$ septa, constricted at the median or supramedian primary septum, smooth, containing minute droplets; in $3 \% \mathrm{KOH}$ turning greenish to yellow-brown when young, dark olivaceous when mature.

Culture characteristics and asexual morph in culture - Colony radius on $\mathrm{CMD}$ at $22{ }^{\circ} \mathrm{C}$ in the dark $7-8 \mathrm{~mm}$ after $1 \mathrm{wk}$, $17-18 \mathrm{~mm}$ after $2 \mathrm{wk}, 28 \mathrm{~mm}$ after $25 \mathrm{~d}$; colony first hyaline to 

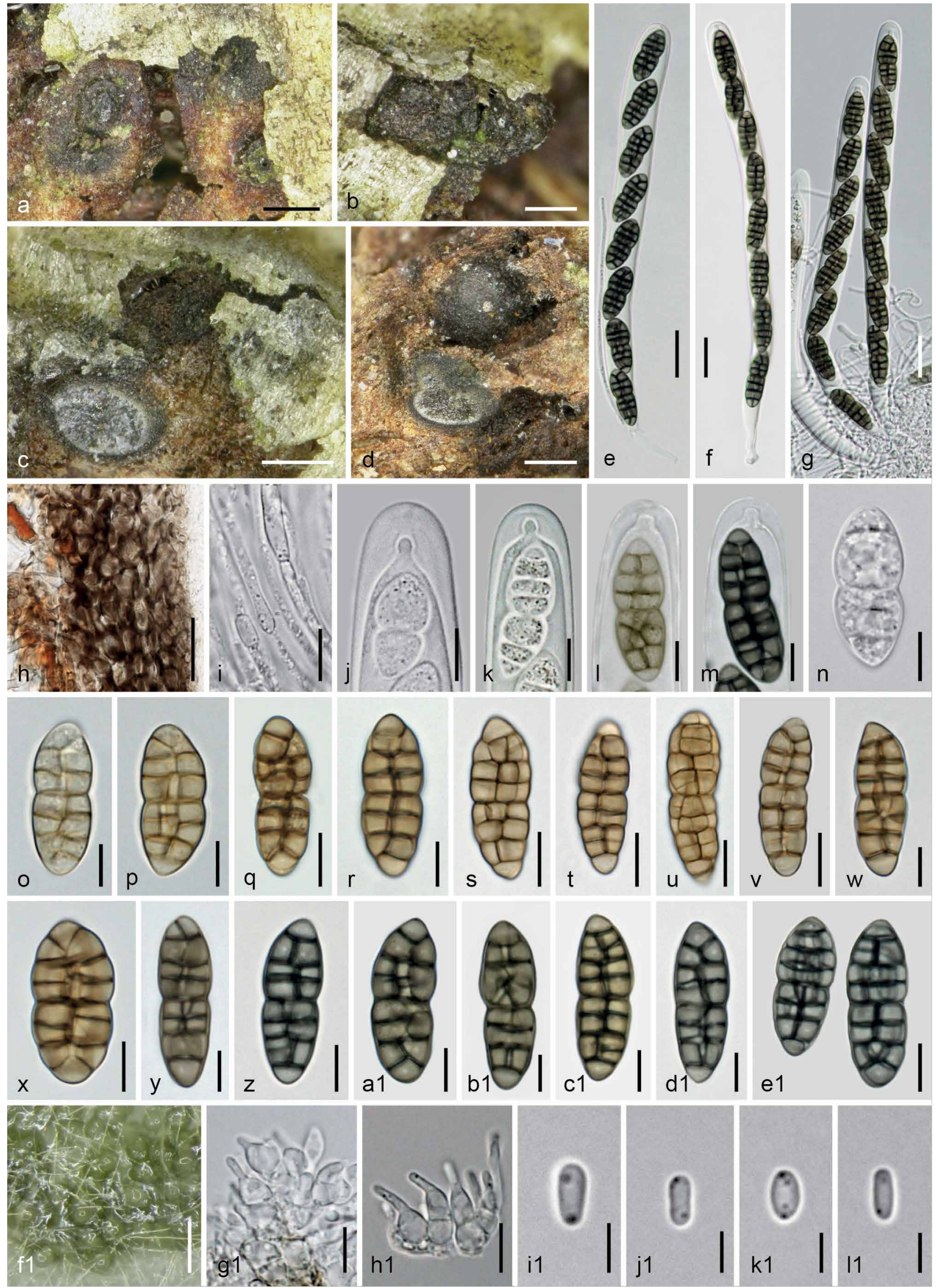

Fig. 20 Parafenestella vindobonensis. a-e1. Sexual morph (WU 37015). a-b. Ascomata in face view; c-d. ascomata in vertical section (with subicular disc in c; on Valsa ascomata in d); e-g. asci (note paraphysis in e); h. peridium in vertical section; i. aged hamathecium; j-m. ascus apices (immature in j-l); $\mathrm{n}-\mathrm{e} 1$. ascospores ( $\mathrm{n}-\mathrm{o}$. immature); f1-I1. asexual morph in culture (CBS 145265 (C302) from CMD at $22^{\circ} \mathrm{C}$ ); f1. pycnidia; g1-h1. phialides; i1-I1. conidia $(e-g, j-n, y-e 1$. in $3 \% \mathrm{KOH}) .-$ Scale bars: $a-d=250 \mu \mathrm{m} ; \mathrm{e}-\mathrm{h}=20 \mu \mathrm{m} ; \mathrm{i}, \mathrm{q}, \mathrm{s}-\mathrm{v}, \mathrm{e} 1=10 \mu \mathrm{m} ; \mathrm{j}-\mathrm{p}, \mathrm{r}, \mathrm{w}, \mathrm{x}-\mathrm{d} 1, \mathrm{~g} 1-\mathrm{h} 1=7 \mu \mathrm{m} ; \mathrm{f} 1=150 \mu \mathrm{m} ; \mathrm{i} 1-\mathrm{l1}=3 \mu \mathrm{m}$ 
whitish, thick, dense, turning olivaceous, later greyish brown from the centre, covered by a velvety mat of whitish to brownish aerial hyphae; reverse dark grey to black; odour indistinct. Pycnidia appearing after $4 \mathrm{~d}$, mostly solitary, greenish; formation of pycnidia not reproducible on CMD. Colony on MEA grey, aerial hyphae forming a loose mesh over numerous pycnidia aggregating in dense masses. Pycnidia c. 60-130 $\mu \mathrm{m}$ diam, hyaline, turning olivaceous from the base, globose, with grey- ish olivaceous conidial drops. Peridium thin, pseudoparenchymatous, olivaceous, surrounded by submoniliform hyphae. Phialides (3.8-)5-7.5(-9.5) × (2-)2.5-4(-4.8) $\mu \mathrm{m}(\mathrm{n}=39)$, sessile, varying from subglobose to lageniform, often with a long neck. Conidia (2.8-)3.5-4(-4.7) × (1.1-)1.3-2(-2.7) $\mu \mathrm{m}$, I/w (1.4-)1.9-2.7(-3) $(n=42)$, oblong to ellipsoid, 1-celled, hyaline, with two or more minute drops, smooth.
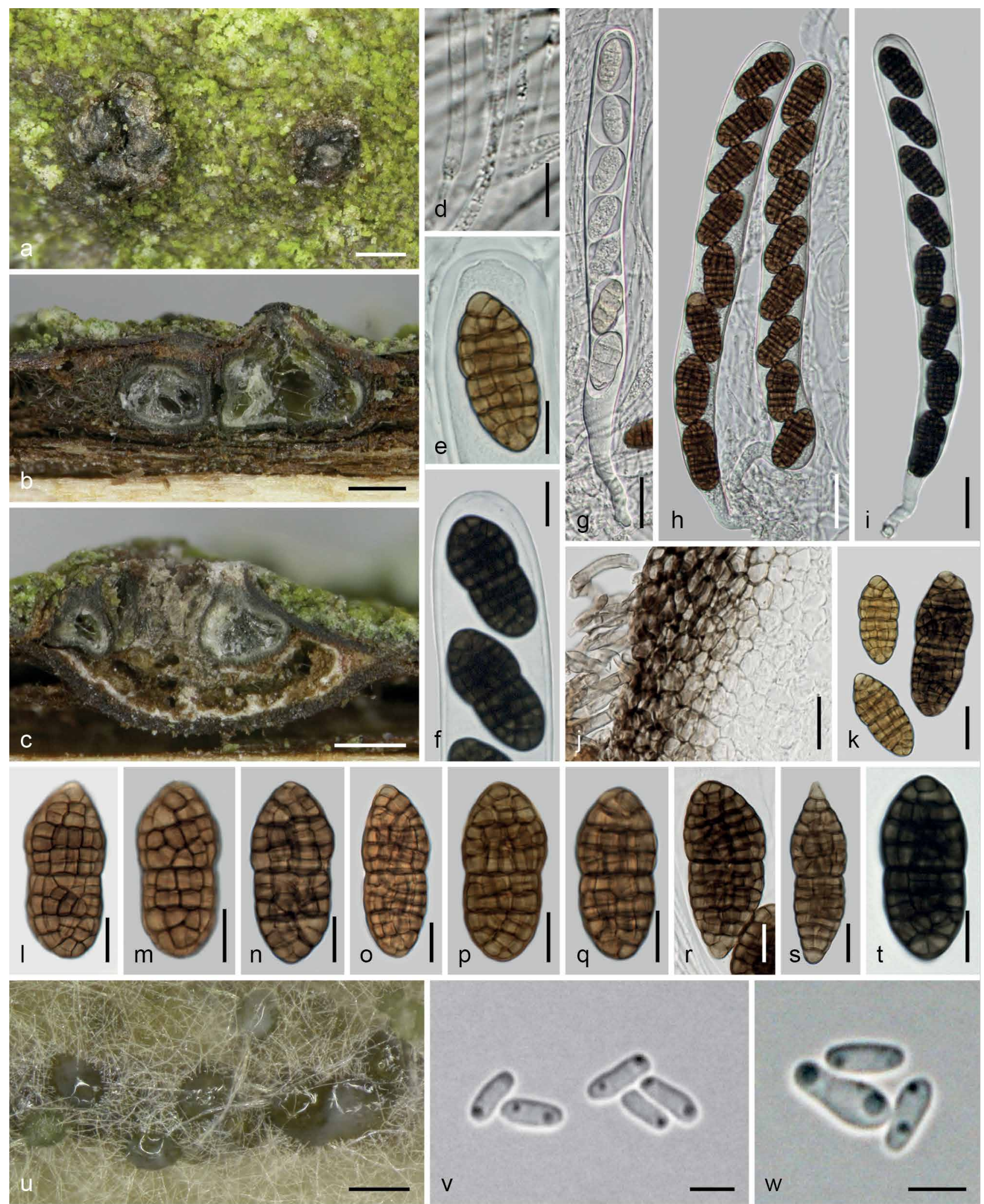

Fig. 21 Synfenestella pyri. a-t. Sexual morph (WU 36996). a. Ascomata in face view; b-c. ascomata in vertical section (c. in a Cytospora (Leucostoma) pseudostroma); d. hamathecial threads; e-f. ascus apices; $g-i$. asci ( $g$. immature; note sheaths around ascospores); j. peridium and subiculum in vertical section; $\mathrm{k}$-t. ascospores (k. showing size variation); $\mathrm{u}-\mathrm{w}$. asexual morph in culture (CBS 144855 (C297) from CMD at $22{ }^{\circ} \mathrm{C}$ ); $\mathrm{u}$. pycnidia and conidial drops; $v-w$. conidia (f, $i, t$. in $3 \% \mathrm{KOH}$ ). - Scale bars: $a-c, u=250 \mu \mathrm{m} ; \mathrm{d}-\mathrm{f}, \mathrm{I}-\mathrm{t}=10 \mu \mathrm{m} ; \mathrm{g}-\mathrm{i}=25 \mu \mathrm{m} ; \mathrm{j}-\mathrm{k}=15 \mu \mathrm{m} ; \mathrm{v}-\mathrm{w}=3 \mu \mathrm{m}$. 
Habitat - On both morphs of a Cytospora (Valsa) sp. on Salix babylonica.

Distribution - Central Europe (Austria), only known from the type locality in Vienna.

Notes - This species is well characterised by its narrow ascospores.

\section{Synfenestella Jaklitsch \& Voglmayr, gen. nov. - MycoBank MB829759}

Etymology. Syn = together with, for its close phylogenetic relationship with Fenestella.

Type species. Synfenestella sorbi Jaklitsch \& Voglmayr.

Ascomata 300-1000 $\mu \mathrm{m}$ diam, globose, subglobose or pyriform, ostiolate, dark brown to black, immersed below bark epidermis, scattered, forming inconspicuous valsoid groups or conspicuous pseudostromatic pustules on pseudostromata or conidiomata of Diaporthales, surrounded and connected by thick-walled subicular hyphae, the latter sometimes short and subsetose in the ostiolar region. Peridium c. 15-130 $\mu \mathrm{m}$ thick, thicker and whitish inside in the apical region, pseudoparenchymatous, dark brown and thick-walled outside and pale to hyaline and thin-walled inside. Hamathecium consisting of numerous 1-3.5 $\mu \mathrm{m}$ wide, branched and anastomosing paraphyses with free ends in a matrix. Asci cylindrical to oblong, bitunicate, fissitunicate, with an ocular chamber, a short or long undulating stipe and simple or knob-like base, containing 4-8 ascospores in (obliquely) uniseriate arrangement. Ascospores ellipsoid, oblong to fusoid, sometimes subglobose, symmetric to slightly curved, with upper part often wider, initially 2-celled, hyaline and surrounded by a swelling sheath, developing additional transverse and longitudinal septa, turning yellow to golden brown (when fresh), finally dark brown with concolorous rounded ends, ends sometimes paler or apiculate upon germination, usually strongly constricted at the primary septum; in $3 \% \mathrm{KOH}$ surface smooth; turning dark olivaceous to blackish brown.

Culture characteristics and asexual morph in culture - Colony on $\mathrm{CMD}$ at $22^{\circ} \mathrm{C}$ in the dark typically producing a diffusing yellow pigment. Pycnidia more or less globose, green to black, densely aggregating and fusing. Phialides lageniform, ampulliform, subglobose or subconical, sessile or produced on short simple conidiophores. Conidia cylindrical, oblong to allantoid, less commonly ellipsoid, 1-celled, hyaline, with 2 drops, smooth; produced on phialides and pegs.

Habitat - On or in pseudostromata or conidiomata of Diaporthales or in loose association with them on Rosaceae.

Distribution - Europe, North America.

\section{Synfenestella pyri Jaklitsch \& Voglmayr, sp. nov. — MycoBank} MB829760; Fig. 21

\section{Etymology. Referring to its plant host, Pyrus communis.}

Holotype. AustriA, Niederösterreich, Ottenschlag, on Cytospora (Leucostoma) sp. on a branch of Pyrus communis, 19 Mar. 2017, W. Jaklitsch (WU 36996; ex-type culture CBS $144855=$ C297).

Ascomata (330-)370-620(-720) $\mu \mathrm{m}(\mathrm{n}=21)$ diam, subglobose to globose, immersed in bark singly or in small groups c. 0.6-1.6 mm diam, on or in loose association with both morphs of a Cytospora (Leucostoma type) sp., on and connected by subhyaline to dark brown, thick-walled, $2-5 \mu \mathrm{m}$ wide subicular hyphae, often only visible on the surface due to spore deposits in bark fissures or slightly erumpent, rarely projecting up to 350 $\mu \mathrm{m}$ above the bark surface. Ostiolar areas 90-270 $\mu \mathrm{m}$ diam, concealed by spore deposits or short-papillate, black, shiny. Peridium 15-70 $\mu \mathrm{m}$ thick, thicker and whitish inside in the osti- olar region, pseudoparenchymatous, consisting of isodiametric cells $(3.8-) 5-9(-11) \mu \mathrm{m}(\mathrm{n}=40)$ diam, outside thick-walled and dark brown, paler to hyaline and thinner-walled to the inside. Hamathecium consisting of numerous $1-3.5 \mu$ m wide, branched and anastomosing paraphyses with free ends in a matrix. Asci (206-)228-268(-296) x (21-)21.8-23.7(-25) $\mu \mathrm{m}(\mathrm{n}=14)$, cylindrical to oblong, bitunicate, fissitunicate, with an ocular chamber, a short to long stipe and simple or knob-like base, containing 4-8 ascospores in (obliquely) uniseriate arrangement; unstable in water. Ascospores (27-)31.5-42(-51.5) $\times$ $(13-) 15-19(-22) \mu \mathrm{m}, \mathrm{I} / \mathrm{w}(1.9-) 2-2.4(-3.1)(\mathrm{n}=50)$, very variable, typically ellipsoid to fusoid, sometimes subglobose, symmetric or inequilateral or slightly curved, initially 2-celled, hyaline and surrounded by a sheath, developing additional septa, turning yellow to golden brown (when fresh), finally dark brown with concolorous ends, with 8-14 distinct transverse and 3-5 longitudinal septa, usually strongly constricted at the primary septum; surface smooth; in $3 \% \mathrm{KOH}$ turning blackish brown when mature.

Culture characteristics and asexual morph in culture - Colony radius on $\mathrm{CMD}$ at $22{ }^{\circ} \mathrm{C}$ in the dark $13 \mathrm{~mm}$ after $1 \mathrm{wk}$, $27 \mathrm{~mm}$ after $4 \mathrm{wk}$; colony circular, thick by a dense whitish to greyish mat of aerial hyphae, first white, turning dull yellow and later becoming concentrically zonate with medium or greyish brown and dark brown zones and a white margin; producing a yellow diffusing pigment; odour indistinct. After $5 \mathrm{~d}$ pycnidia densely disposed, appearing on and around the plug or in rings, green, turning black, 120-300 $\mu$ m diam, becoming fused to larger complexes in aged cultures, emitting conidia in white to olivaceous turbid drops. Phialides (4-)4.5-7(-7.8) $\times$ $(2-) 2.3-3.3(-4) \mu \mathrm{m}(\mathrm{n}=19)$, crowded, sessile or on intercalary cells, mostly lageniform, also subconical, ampulliform to subglobose. Conidia (3.5-)4-4.8(-5.5) × (1.2-)1.3-2(-2.5) $\mu \mathrm{m}, \mathrm{I} / \mathrm{w}(2.2-) 2.4-3.2(-3.8)(\mathrm{n}=32)$, cylindrical, oblong or allantoid, 1-celled, smooth, with 2 guttules.

Habitat - On Cytospora sp. (both morphs; sexual morph of the Leucostoma type) on Pyrus communis.

Distribution - Europe (Austria), only known from the type locality.

Notes - Synfenestella pyri is an inconspicuous fungus. It differs from Parafenestella spp. occurring on Rosaceae by the swelling sheath visible in immature ascopores within asci.

Synfenestella sorbi (P. Karst.) Jaklitsch \& Voglmayr, comb. nov. - MycoBank MB829761; Fig. 22

Basionym. Cucurbitaria sorbi P. Karst., Bidrag Kannedom Finlands Natur Folk 23(2): 62. 1873.

Synonyms. Gibberidea sorbi (P. Karst.) Kuntze, Revis. Gen. PI. (Leipzig) 3(2): 481.1898.

Fenestella bavarica Kirschst., Ann. Mycol. 34(3): 193. 1936

Lectotype of Cucurbitaria sorbi, here designated. FINLAND, Aboe, on branches of Sorbus aucuparia, soc. Cytospora (Leucostoma) sp., 8 Apr. 1861, P.A. Karsten ( $\mathrm{H} 3686$, from the herbarium Karsten; MBT385692). Epitype of Cucurbitaria sorbi, here designated: AustRIA, Niederösterreich, Reichenau, Rax, near Seehütte, on twig of Sorbus aucuparia, on/soc. Cytospora sp. (Leucostoma type; holomorph), 21 Sept. 2014, W. Jaklitsch (WU 36992; MBT385693; ex-epitype culture from ascospores CBS 144862 = FR; culture from conidia $=\mathrm{FRa}$ )

Pseudostromatic pustules when present $0.9-4.7 \mathrm{~mm}$ diam, erumpent from bark and projecting up to $1.5 \mathrm{~mm}$ beyond the bark surface, subglobose to pulvinate, roundish to longish in outline; surface brown (compacted subiculum) to dark grey or black (ascomatal apices), sometimes containing also narrow cylindrical ostiolar necks of the Diaporthe or Leucostoma host. Ascomata (330-)425-745(-990) $\mu \mathrm{m}(\mathrm{n}=47)$ diam, globose, subglobose or pyriform, immersed in bark in rows or valsoid configuration, often laterally in the ostiolar region of the fungal 
host or inserted in the pustules on a single or two levels upright or obliquely and convergent, singly or up to c. 20 individuals loosely or tightly aggregated and surrounded by usually ample dark brown subiculum, partly directly on the fungal host; subiculum also present below epidermis. Ascomatal apices containing inconspicuous ostiolar openings $120-300(-600) \mu \mathrm{m}(\mathrm{n}=46)$ diam, black, whitish when injured, often flattened. Subiculum consisting of hyaline, pale to dark brown, thick-walled, 2-7 $\mu \mathrm{m}$ (widened up to $9.5 \mu \mathrm{m}$ at points connecting to the peridium) wide hyphae, darker brown, particularly thick-walled, often short and subsetose ('hyphal appendages') near the ascomatal apices. Peridium 20-65 $\mu \mathrm{m}$ thick, up to $130 \mu \mathrm{m}$ at the ostiolar level, pseudoparenchymatous, consisting of cells (4-)7-14(-23) $\mu \mathrm{m}$ $(n=63)$ diam, outside very dark brown, thick-walled, to the inside gradually paler and thinner-walled and terminated by a narrow layer of pale brownish compressed cells. Hamathecium
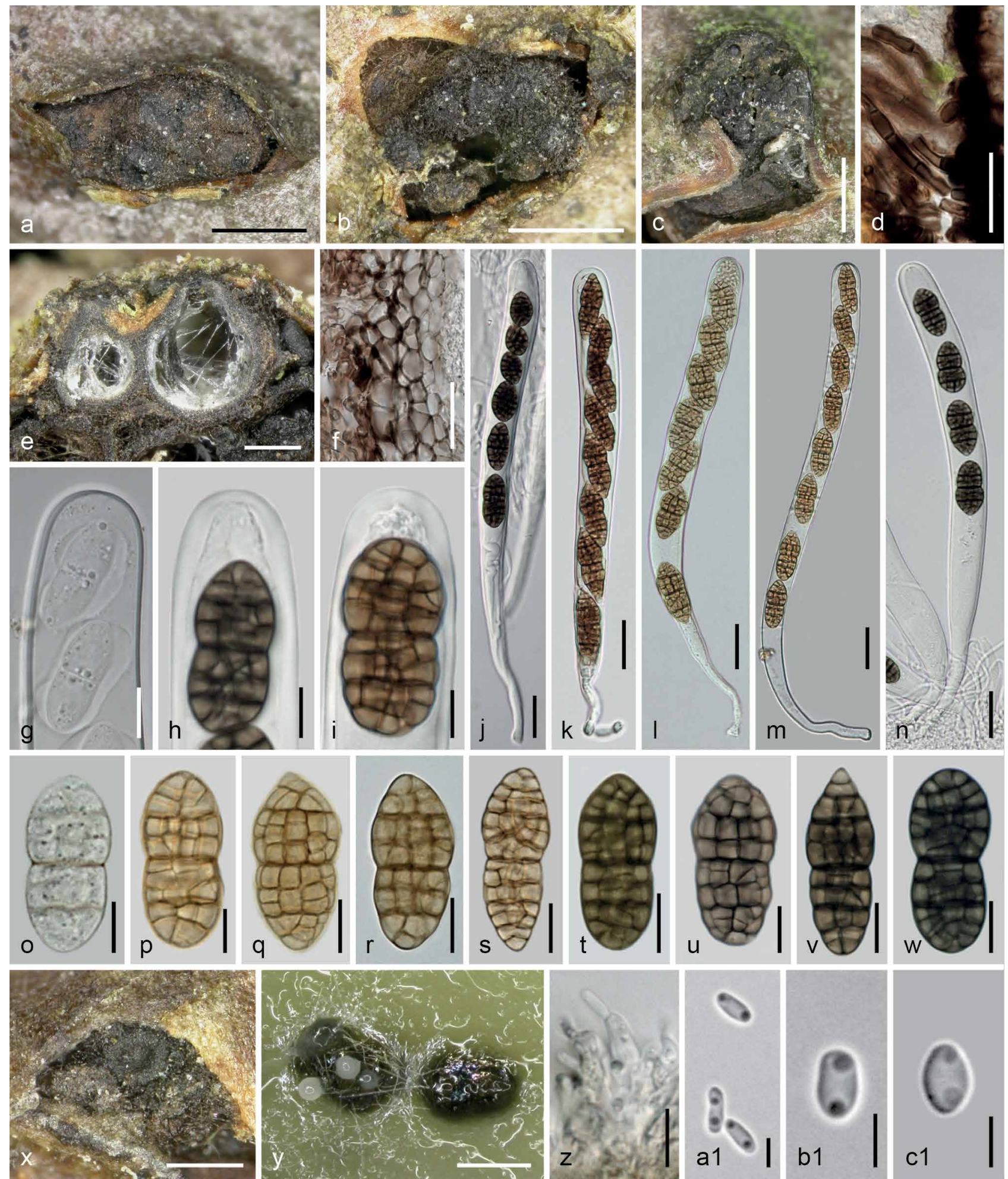

Fig. 22 Synfenestella sorbi. a-w. Sexual morph. a-b. Ascomata/pseudostromata in face view; c. Diaporthe impulsa pseudostroma with a small S. sorbi ascoma inserted laterally; d. subsetose subicular hyphae at ascoma apex; e. ascomata above Diaporthe ascomata in vertical section; f. peridium and subiculum in vertical section; $\mathrm{g}-\mathrm{i}$. ascus apices (g. immature; note sheath around ascospores); j-n. asci; o-w. ascospores (o. immature; p. young); $x$. pycnidia on the natural host; $\mathrm{y}-\mathrm{c} 1$. asexual morph from $\mathrm{CMD}$ at $22^{\circ} \mathrm{C} ; \mathrm{y}$. pycnidia and conidial drops; $\mathrm{z}$. phialides; a1-c1. conidia $(\mathrm{h}, \mathrm{j}, \mathrm{n}-\mathrm{o}, \mathrm{t}-\mathrm{w}$. in $3 \% \mathrm{KOH})$. a, k, $\mathrm{u}-\mathrm{v}$. Cucurbitaria sorbi lectotype H 3686; b, d-f, l, q-r, z-b1. WU 36994/CBS 144858 (C196); c, i, p, w. WU 36995 (C298); g, m, o, s-t, x-y, c1. WU 36992/CBS 144862 (FR); h, j. Fenestella bavarica holotype B 700016482; n. WU 36993. - Scale bars: $a-c=1 \mathrm{~mm} ; \mathrm{d}, \mathrm{f}, \mathrm{j}-\mathrm{n}=25 \mu \mathrm{m} ; \mathrm{e}, \mathrm{x}-\mathrm{y}=300 \mu \mathrm{m} ; \mathrm{g}, \mathrm{q}-\mathrm{w}=10$ $\mu \mathrm{m} ; \mathrm{h}-\mathrm{i}, \mathrm{o}-\mathrm{p}, \mathrm{z}=7 \mu \mathrm{m} ; \mathrm{a} 1-\mathrm{c} 1=3 \mu \mathrm{m}$. 
consisting of numerous tightly packed, richly branched, 1-3 $\mu \mathrm{m}$ wide ?paraphyses. Asci (199-)228-297(-377) $\times(15-) 18-$ 21 $(-23) \mu \mathrm{m}(n=64)$, cylindrical to oblong, bitunicate, fissitunicate, with an ocular chamber, a usually long undulating stipe and simple or knob-like base, containing 4-8 ascospores in (obliquely) uniseriate arrangement. Ascospores (22-)28$35(-43.5) \times(10-) 13-15.5(-18.5) \mu \mathrm{m}, \mathrm{I} / \mathrm{w}(1.6-) 2-2.5(-3.2)$ $(n=171)$, very variable in shape, ellipsoid, oblong to fusoid, first hyaline, 2-celled and with a swelling sheath, developing 3-5 main thick septa and later additional thin septa, eventually with $7-13$, rarely 15 , distinct transverse and (1-)2-4 longitudinal septa, turning golden yellow, yellow brown, pale or reddish brown and finally dark brown; often strongly constricted at the primary septum, upper part often wider, ends usually broadly rounded or upper end narrowly and lower broadly rounded, concolorous, only paler or apiculate upon germination; smooth, containing small droplets, often smaller in the ascus apex, often several in the ascus aborted or aberrant; in $3 \% \mathrm{KOH}$ turning dark olivaceous to blackish brown. Sexual morph sometimes accompanied by black, shiny, globose, non-papillate, apically collapsing-cupulate pycnidia 90-300 $\mu \mathrm{m}$ diam seated on scant to ample dark brown subiculum on innermost bark layers around old Leucostoma pseudostroma (black encasement) and on ?Diaporthe ascomata.

Culture characteristics and asexual morph in culture - Colony radius on $\mathrm{CMD}$ at $22^{\circ} \mathrm{C}$ in the dark $8 \mathrm{~mm}$ after $1 \mathrm{wk}$, $21 \mathrm{~mm}$ after $3 \mathrm{wk}$; colony circular, thick, dense, first white to bright yellow, aerial hyphae forming a thick white mat, reverse yellow, yellow pigment diffusing into the agar, later colony turning greyish brown from the centre, diffusing pigment turning dull yellow; odour indistinct. After $4 \mathrm{~d}$ pycnidia numerous, mostly covered by a white mat of aerial hyphae, $120-330 \mu \mathrm{m}$ diam, more or less globose, hyaline to greenish olivaceous, turning black, densely aggregating and forming stromatic masses; conidia appearing in whitish turbid drops from many ostioles; peridium pseudoparenchymatous, yellow to dark olivaceous, surrounded by olivaceous to brown hyphae. Phialides $(4.8-) 5-8(-11.5) \times 2-4(-5.7) \mu \mathrm{m}(\mathrm{n}=15)$, very variable, subglobose to ampulliform to lageniform, on short simple conidiophores, also with lateral pegs or on hyaline intercalary cells. Conidia (3.3-)4-4.5(-5) $\times(1.2-) 1.5-2(-2.8) \mu \mathrm{m}, \mathrm{I} / \mathrm{w}$ $(1.5-) 2.1-3.1(-3.9)(n=64)$, cylindrical, oblong to allantoid, less commonly ellipsoid, 1-celled, hyaline, with 2 drops, smooth.

Habitat - On both morphs of Cytospora sp. of the Leucostoma type, in pseudostromata on effete ascomata of Diaporthe impulsa or in loose association with it on Sorbus aucuparia.

Distribution - Europe, North America fide Barr (1990; under Fenestella subcaespitosa) and Mirza (1968; under Cucurbitaria sorbi).

Other materials examined. AusTRIA, Osttirol, Prägraten am Großvenediger, Hinterbichl, Umbalfälle, on cf. Diaporthe impulsa on a dead attached branch of Sorbus aucuparia, soc. cf. Karstenula sp., Mollisia caespiticea, 17 June 2015, H. Voglmayr \& W. Jaklitsch (WU 36994; culture CBS 144858 = C196); Steiermark, Deutschlandsberg, Freiländer Alm, W Freiländer Almhütte; E15 $02^{\prime} 57^{\prime \prime}$ N46 ${ }^{\circ} 54^{\prime} 47^{\prime \prime}$, elev. 1410 m, on Diaporthe impulsa on a branch of Sorbus aucuparia on the ground, 3 May 2017, G. Friebes (WU 36995; culture C298); highway parking place close to the Pack tunnel, on a branch of Sorbus aucuparia attached to the tree, soc. Diaporthe impulsa, 17 Feb. 1995, W. Jaklitsch W.J. 499 (WU 36993). - GeRMANY, Bavaria, Bayerisch Häusl bei Eisenstein, on Cytospora (Leucostoma) on branches of Sorbus aucuparia, June 1935, W. Kirschstein (B 700016482, holotype of Fenestella bavarica)

Notes - In H two syntypes of Cucurbitaria sorbi are extant; No. 3687 (Finland, Vaasa, on Sorbus, 12 Aug. 1867, P.A. Karsten) contains mostly Dothiora pyrenophora, a fungus with 3-septate ascospores (possibly Nigrograna sp.), an immature nectriaceous fungus and only little and old $S$. sorbi (ascospore measurements given on the label: $25-30 \times 12-14$ ). In contrast,
No. 3686 contains good material and is thus selected as lectotype. The latter was also examined by M.E. Barr according to the annotation slip. Synfenestella sorbi has been found in direct association with both Cytospora sp. (Leucostoma morph) and Diaporthe impulsa. Also other ascomycetes are associated with the fungus, thus parasitism on other fungi may be possible. Fenestella bavarica is clearly a synonym of $S$. sorbi. In its holotype, S. sorbi grew on Cytospora (Leucostoma morph), has typical long-pedicellate asci with often aberrantly developed ascospores, many aborted or distorted or even globose. At the pustule surface cylindrical Leucostoma ostioles peek through brown compacted subiculum of the Synfenestella; also a Tympanis is present on thin twigs.

Synfenestella sorbi is extremely variable in appearance, ranging from solitary ascomata (on Diaporthe) to large conspicuous pseudostromata. Hyphal appendages sensu Barr (1990; sub Fenestella subcaespitosa) are subicular hyphae and occur variably in the entire family. In S. sorbi they are often but not always differentiated from other hyphae around the ascomatal apices by having a nearly setose appearance, darker colour and slightly thicker walls. The long-pedicellate asci were already described by Mirza (1968; under Cucurbitaria sorbi). Cucurbitaria subcaespitosa from $S$. aria is clearly a different species and here combined in Neocucurbitaria.

There are some sequence differences between isolates derived from specimens containing the fungal host Cytospora (Leucostoma) and those growing on Diaporthe impulsa. However, as these differences are not convincing and the specimens are morphologically indistinguishable, we do not recognise two separate species. In the lectotype H $3686 \mathrm{~S}$. sorbi is associated with Cytospora, therefore we epitypify it with material containing the same fungal host.

\section{KEY TO FENESTELLOID SPECIES}

Fungal hosts are only given in the key when different from or additional to Cytospora spp. Parafenestella ostryae from Ostrya carpinifolia (Wanasinghe et al. 2017b) is not included, as we have not seen material of this species. Some species, particularly Fenestella media vs F. subsymmetrica, Parafenestella salicis vs $P$. pseudosalicis, or $P$. austriaca vs $P$. rosacearum cannot be safely distinguished morphologically.

1. Ascospores with a gelatinous sheath $\ldots \ldots \ldots \ldots \ldots 2$

1. Ascospores lacking a sheath . . . . . . . . . 5

2. Sheath persistent during ascospore development. .... . 3

2. Sheath only present initially in the ascus. . . . . . . 4

3. Ascospores (52-)58-67(-72) × (16-)19-23(-26) $\mu \mathrm{m}, \mathrm{I} / \mathrm{w}$ $2.5-3.7$, fusoid to subclavate, with c. 17-25 transverse and 3-7 longitudinal septa, surrounded by a sheath around each hemisphere, quickly swelling and losing contours in water; on Ulmus glabra ................ Seltsamia ulmi

3. Ascospores (36-)43-54(-60) × (13-)17-22(-28) $\mu \mathrm{m}, \mathrm{l} / \mathrm{w}$ 2-3.4, clavate to fusoid, with 12-17 transverse and 4-5 longitudinal septa; on Acer granatense.

Fenestella granatensis

4. Ascomatal groups inconspicuous, ascospores (27-)32-42 $(-51) \times(13-) 15-19(-22) \mu \mathrm{m}, \mathrm{I} / \mathrm{w} 2-3$, typically ellipsoid to fusoid, ends concolorous, with 8-14 distinct transverse and 3-5 longitudinal septa; on Pyrus .... . Synfenestella pyri

4. Ascomata often forming conspicuous pseudostromatic pustules, ascospores (22-)28-35(-44) × (10-)13-16(-19) $\mu \mathrm{m}$, I/w 1.5-3.2, ellipsoid, oblong to fusoid, with 7-13(-15) transverse and (1-)2-4 longitudinal septa, ends concolorous, only paler or apiculate upon germination; on Sorbus aucuparia................... Synfenestella sorbi 
5. Ascomata immersed evenly or randomly in bark, ascospores (32-)38-52(-63) × (14-)16-21(-25) $\mathrm{\mu m}, \mathrm{I} / \mathrm{w}$ $1.8-3.3$, with 12-18(-20) transverse and 3-7 longitudinal septa, with wall distinctly thicker than septa; ends sometimes apiculate; on UImus spp. . . . . Protofenestella ulmi

5. Ascomata forming inconspicuous groups or well-defined pseudostromatic pustules . . . . . . . . . . 6

6. Ascospores (36-)49-65(-73) $\times(14-) 18-25(-31) \mu \mathrm{m}$, mostly fusoid, with $13-20$ transverse and $4-6(-7)$ longitudinal septa, often with hyaline, 2-7 $\mu \mathrm{m}$ long terminal apiculi; on Alnus glutinosa and possibly Quercus

Fenestella fenestrata

6. Ascospores smaller . . . . . . . . . . . . 7

7. Ascospores (32-)41-53(-61) ×(13-)15-19(-23) $\mu \mathrm{m}, \mathrm{l} / \mathrm{w}$ $2-3.6$, with 11-16(-20) transverse and 2-4 longitudinal septa; on Quercus and Salix . . Fenestella parafenestrata

7. Ascospores smaller . . . . . . . . . . . . . 8

8. Ascomata forming more or less compact pustules, ascospores $(28-) 32-46(-55) \mu \mathrm{m}$ long . . . . . . . . . 9

8. Ascomata forming inconspicuous groups, ascospores shorter . . . . . . . . . . . . . . . . . . . . . . 14

9. Ascospores (30-)32-41(-47) $\times(14-) 15-19(-24) \mu \mathrm{m}, \mathrm{l} / \mathrm{w}$ 1.8-2.6, with (9-)10-14(-16) transverse and 3-5 longitudinal septa and pale non-apiculate ends; on Acer opalus . . . . . . . . . . . . . . . . . Cucitella opali

9. Ascopores with apiculate ends . . . . . . . . 10

10. Ascospores (31-)36-46(-55) $\times(11-) 15-20(-23) \mu \mathrm{m}$, I/w 2-3, with 11-14(-16) transverse and 2-4 longitudinal septa and usually broad, often hyaline terminal cells sometimes transformed into an ampulliform cellular appendage; on Crataegus monogyna .......... Fenestella crataegi

10. Apiculi not ampulliform, up to $2 \mu \mathrm{m}$ long, to $5 \mu \mathrm{m}$ when old

. 11

11. Ascospores with distinctly submedian primary septum, clavate to ellipsoid, (34-)36-45(-49) ×(13-)15-19(-22) $\mu \mathrm{m}, \mathrm{I} / \mathrm{w} 2-2.8$, with 11-16 distinct transverse and 3-5 longitudinal septa; on Acer saccharum .

Fenestella gardiennetii

11. Ascospores ellipsoid or fusoid, with submedian to median primary septum . . . . . . . . . . . . . . . . . 12

12. On Viburnum spp.; ascospores (29-)38-46(-49) $\times(12-)$ $15-18(-22) \mu \mathrm{m}, \mathrm{l} / \mathrm{w} 2-3$, with 11-16 transverse and 3-6 longitudinal septa, sometimes distinctly pointed at ends Fenestella viburni

12. On diverse woody hosts $\ldots \ldots \ldots \ldots \ldots \ldots \ldots$

13. Ascospores (30-)34-44(-53) $\times(12-) 14-18(-21) \mu \mathrm{m}, \mathrm{l} / \mathrm{w}$ $2-3.3$, mostly asymmetric, with indistinct $11-18$ transverse and 3-6(-7) longitudinal septa . . . . . Fenestella media

13. Ascospores (28-)34-44(-55) $\times(13-) 15-20(-25) \mu \mathrm{m}, \mathrm{I} / \mathrm{w}$ $1.8-3$, asymmetric to subsymmetric, with distinct $11-16$ $(-18)$ transverse and 3-6 longitudinal septa

Fenestella subsymmetrica

14. In (sub)alpine regions on Cotoneaster and Salix; ascospores (19-)24-30.5(-35) × (10.5-)12-14(-15.5) $\mu \mathrm{m}$, I/w 1.4-2.9, with (7-)8-12(-15) transverse and (2-)3-4 longitudinal septa and concolorous ends

14. Not exclusively in (sub)alpine regions . . . . . . . 15

15. On Melanconis alnion Alnus; ascospores (19-)26-34(-39) $\times(10-) 13-17(-18) \mu \mathrm{m}, \mathrm{l} / \mathrm{w}$ 1.7-2.8, with 8-14(-17) distinct transverse and $2-4$ longitudinal septa and concolorous, rarely paler ends ...... Parafenestella tetratrupha

15. On other hosts . . . . . . . . . . . . 16

16. On species of Diaporthe . . . . . . . . . . . 17

16. Not known to occur on Diaporthe .......... 18
17. Ascospores (22-)24-30(-32) ×(11-)12-14(-16) $\mu \mathrm{m}, \mathrm{I} / \mathrm{w}$ 1.6-2.5, with (7-)8-12(-13) transverse and 3-4 longitudinal septa and often subacute concolorous, sometimes lighter ends; on Acer pseudoplatanus

Parafenestella pseudoplatani

17. Ascospores (26-)29-40(-47) ×(11-)13-17(-19) $\mu \mathrm{m}, \mathrm{I} / \mathrm{w}$ 1.9-2.7, with (8-)9-13(-15) transverse and 3-6 longitudinal septa and often broadly rounded, paler to hyaline end cells; on Corylus . . . . . . . . . Parafenestella germanica

18. On Salix spp. . . . . . . . . . . . . . . . . . . . . . . 19

18. On Rosaceae. . . . . . . . . . . . . . . . 23

19. Ascospores (20-)24-31(-38) × (8.5-)9.5-11(-13) $\mu \mathrm{m}$, I/w 2-3.4, with 7-9(-11) thick transverse and 1-2(-3) longitudinal septa and concolorous or slightly paler ends

Parafenestella vindobonensis

19. Ascospores wider . . . . . . . . . . . . 20

20. Ascospores (33-)36-44(-50) $\times(14-) 16-19(-22) \mu \mathrm{m}, \mathrm{I} / \mathrm{w}$ $2-2.6$, with $11-16$ distinct transverse and $3-5$ longitudinal septa and mostly concolorous ends

................ Parafenestella parasalicum

20. Ascospores smaller . . . . . . . . . . . . . 21

21. Ascospores (22-)27-33(-40) ×(11-)13-16(-18) $\mu \mathrm{m}, \mathrm{I} / \mathrm{w}$ $1.7-2.5$, with $9-13(-14)$ transverse and $3-4$ longitudinal septa and concolorous, rarely slightly paler ends ......

Parafenestella salicum

21. Ascospores with fewer septa . . . . . . . . . 22

22. Ascospores (20-)23-29(-34) $\times(10-) 11-14(-15) \mu \mathrm{m}, \mathrm{l} / \mathrm{w}$ 1.5-2.7, often inequilateral, with often indistinct (5-6-) $7-10(-11)$ transverse and (1-)2-3 longitudinal septa, the latter often forming parallel lines; ends concolorous, rarely hyaline ................ Parafenestella salicis

22. Ascospores (23-)25-29(-32) × (11-) 12-14(-15) $\mu \mathrm{m}, \mathrm{I} / \mathrm{w}$ $1.9-2.7$, symmetric, with distinct $7-10(-11)$ transverse and 2-4 longitudinal septa; ends concolorous

Parafenestella pseudosalicis

23. Ascospores (23-)28-36(-42) $\times(11-) 12-16(-18) \mu \mathrm{m}, \mathrm{I} / \mathrm{w}$ $1.9-2.8$, with $7-12(-14)$ transverse and $1-3(-5)$ longitudinal septa; end cells concolorous except for a truncate to slightly convex hyaline terminal part of their walls

Parafenestella faberi

23. Ascospore end cells rounded and concolorous or diffusely to entirely paler to hyaline . . . . . . . . . . 24

24. Ascospores (25-)27-33(-38) ×(12-)13-15(-16) $\mu \mathrm{m}, \mathrm{l} / \mathrm{w}$ 1.9-2.6, ellipsoid, symmetric, with 9-13(-14) distantly spaced transverse and 3-4(-5) longitudinal septa . . . .

Parafenestella austriaca

24. Ascospores (23-)28-35(-45) × (11-)13-17(-19) $\mu \mathrm{m}, \mathrm{I} / \mathrm{w}$ $1.7-2.6$, symmetric to inequilateral, with $(7-) 9-13(-15)$ transverse and $2-4(-5)$ longitudinal septa .

. Parafenestella rosacearum

\section{DISCUSSION}

\section{Other species of Fenestella (and Cucurbitaria)}

See notes under the species described in the Taxonomy section above and in Jaklitsch et al. (2018), where many names in Cucurbitaria are commented on. In this work we studied particularly European species of Fenestella s.lat. with available fresh material. We did not study, e.g., F. betulae nor F. parvula, because no fresh material from Betula was available. No type material of Fenestella cydoniae (basionym Pleospora cydoniae) could be located. The protologue may suggest affiliation with F. media or a similar species. Fenestella microspora was described from Corylus in France with ascospores 10-11 × 6-7 $\mu \mathrm{m}$, thus it is apparently not a member of Cucurbitariaceae. 
Fenestella phaeospora is not a member of the Cucurbitariaceae phylogenetically (unpublished results). Fenestella prunastri from Prunus spinosa in Luxemburg was described with ascospores having 3-4 transverse and 1 longitudinal septa, 20-22 $\times 8-9 \mu \mathrm{m}$, pale yellow, as similar to $F$. lycii, i.e., not a species of Fenestella, but possibly rather belonging to Camarosporidiellaceae or Coniothyriaceae. Species with muriform ascospores on Lycium spp. (Cucurbitaria varians, Fenestella lycii) are referable to Camarosporium. Fenestella subvestita from Alnus glutinosa in Lyngby, Denmark, was described with ascospores $15-19 \times 7.5-8.5 \mu \mathrm{m}$ having 3 transverse and 1 longitudinal septa, i.e., not a species of Cucurbitariaceae. The genera Teichospora and Thyridium may house additional cucurbitariaceous species, but the task to examine all available type materials of these genera is beyond this work.

\section{Molecular phylogeny}

As shown in Fig.1, there is significant infraspecific variation in taxa of the genera Parafenestella and Synfenestella. On the other hand, in those Fenestella species, where several isolates were available, F. media, F. subsymmetrica and F. viburni, there is no or very little variation in DNA sequences of all markers. This is particularly interesting, as most species of all genera grow on Cytospora spp., i.e., they share the same ecology. The reason for the infraspecific variability is unclear but may indicate that these lineages are in the process of ongoing speciation, probably triggered by host specificity on different Cytospora hosts. This, however, is difficult to assess, as the identification of the effete Cytospora hosts is usually impossible when ascomata are produced.

\section{Ecology, hosts and development}

Fenestelloid fungi produce their ascomata and conidiomata on or in tight association with effete ascomata and conidiomata of mostly if not always Diaporthales, in temperate zones mostly in the cold season (late autumn to early spring). This means that climatic conditions have first to be favourable enough to promote development of the fungal host and secondly, the following period must be long and favourable enough to support ascomatal development and maturation. In the cold season such periods are often short and irregular, as temperatures may variably decrease below $0{ }^{\circ} \mathrm{C}$ often terminating fungal development, and this may influence development of ascospores dramatically. Moisture is usually not a criterion limiting fungal development in the cold season, but in recent years and decades, even this has changed in many temperate regions, where little precipitation occurs even in winter. At high elevations (montane to alpine levels) impact on development by climatic variation is even more drastic. One example is Synfenestella sorbi, whose plant host Sorbus aucuparia occurs from lowlands to subalpine levels. As a result, ascospores often vary tremendously with regard to size and shape, even within a single ascus, in this but also other species. Often only one to four ascospores in an ascus are mature and others are aborted. The resulting drastic infraspecific variation of ascospore characters makes species recognition and identification using morphological traits alone extremely difficult.

Also, size and development of ascomatal groups or pseudostromata vary considerably, as they depend on the size and development of the Cytospora (and other) hosts, thickness of twigs or branches, and again on (micro-)climatic conditions on twigs and branches determining the magnitude of infection of the present host pseudostromata or conidiomata. As the latter are mostly effete when colonised by the Fenestella, we have no information on host identity on the species level, which is difficult also due to the unsettled taxonomy of Cytospora and the fact that several Cytospora species may occur on a single host plant. Specificity toward the fungal host is unknown, as, e.g., Fenestella media occurs on several plant hosts, which may be substrates of different Cytospora spp. Thus, F. media either has a wide specificity regarding its Cytospora host species or alternatively, it grows on a single Cytospora sp., which occurs on many different plants. As species of Cytospora are numerous and common, we expect that many more species of fenestelloid fungi will be described in future, at least from temperate zones worldwide.

\section{Morphological characters}

Ascomata of fenestelloid fungi are always immersed in to erumpent from bark and have a marked tendency to form groups, besides forming solitary ascomata in a colony, too. Numbers of ascomata in a group is often less than 10 in Parafenestella, but may be much higher in Fenestella and Synfenestella. A few species of the latter genera may produce conspicuous pseudostromatic pustules. Morphological variation in Synfenestella is remarkable, as fructifications of $S$. pyri are very inconspicuous and consist of only few ascomata in a group, and asci are mostly short-stipitate, while in contrast $S$. sorbi often forms large conspicuous pseudostromata and asci are long-stipitate. However, the swelling sheath in young ascospores within asci unites the two species. It should be borne in mind that elongated ascus stipes and partly biseriate arrangement of ascospores in microscopic mounts may also be consequences of exerting pressure on the cover slip in order to free asci from the hymenium. The peridium of Fenestella was characterised as 3-layered by Barr (1990; sub Fenestellaceae). However, the innermost narrow layer of brownish compressed and elongated cells is not always present and the outer two layers (dark brown, of thick-walled cells outside, followed by thinner-walled and paler brown to hyaline cells) are, after consideration of all species, rather a single layer with internal variation. The outermost region can be narrow and then more easily be interpreted as a layer of its own, particularly when the transition to lighter colour and thin walls, which basically is always gradual, takes place at a short distance. This is especially obvious in $F$. fenestrata and $F$. parafenestrata and in the three sibling species $F$. media, $F$. subsymmetrica and $F$. viburni. The hamathecium has been identified as apically free paraphyses present among immature asci in several species, thus this may be a character common to the entire family Cucurbitariaceae (see also Jaklitsch et al. 2018). Morphology and illustration of several species in this work was done using dried material; thus images of fresh vital ascospores are missing. However, ascospores of fenestelloid fungi are mostly yellow-brown or golden-brown when fresh, but turn dark brown upon drying and may often be dark reddish brown in herbarium material. They turn greenish olivaceous when immature to blackish brown when mature in $3 \% \mathrm{KOH}$. Verruculose ornamentation has been seen in many species. This might however be an effect of drying of the perispore.

\section{Asexual morphs in the Cucurbitariaceae}

As pointed out by Jaklitsch et al. (2018), asexual morphs of the Cucurbitariaceae do not offer sufficient traits for reliable distinction at the species or generic level. As we have seen here, asexual morphs of all fenestelloid fungi are morphologically similar and may be termed phoma-like.

Acknowledgments We thank the fungarium curators $A$. Bond $(\mathrm{K}), \mathrm{B}$. Buyck $(P C)$, P. Clerc (G), M. Hyvarinen and O. Miettinen (H), A. Igersheim (W), R. Lücking (B), O. Morozova (LE), C. Scheuer (GZU), W. Till (WU) and D. Triebel $(M)$ for sending and managing collections, R. Berndt $(Z)$ and $A$. Igersheim (W) also for information on specimens, A. Akulov, J. Fournier, G. Friebes, A. Gardiennet, I. Greilhuber, R. Moosbeckhofer, K. Pätzold, E. Popov, S. Tello and $\mathrm{B}$. Wergen for fresh material or data. The financial support by the Austrian Science Fund (FWF; project P25870-B16) is gratefully acknowledged. 


\section{REFERENCES}

Barr ME. 1990. Melanommatales (Loculoascomycetes). North American Flora. Series II 13: 1-129.

Boehm EWA, Mugambi GK, Miller AN, et al. 2009. A molecular phylogenetic reappraisal of the Hysteriaceae, Mytilinidiaceae and Gloniaceae (Pleosporomycetidae, Dothideomycetes) with keys to world species. Studies in Mycology 64: 49-83.

Brockmann I. 1976. Untersuchungen über die Gattung Discostroma Clements (Ascomycetes). Sydowia 28: 275-338.

Carbone I, Kohn LM. 1999. A method for designing primer sets for speciation studies in filamentous ascomycetes. Mycologia 91: 553-556.

Checa J, Jaklitsch WM, Blanco MN, et al. 2015. Two new species of Thyronectria from Mediterranean Europe. Mycologia 107: 1314-1322.

Crous PW, Groenewald JZ. 2017. The genera of fungi-G 4: Camarosporium and Dothiora. IMA Fungus 8: 131-152.

De Hoog GS, Gerrits van den Ende AHG. 1998. Molecular diagnostics of clinical strains of filamentous basidiomycetes. Mycoses 41: 183-189.

Fuckel L. 1870 '1869-1870'. Symbolae Mycologicae. Beiträge zur Kenntnis der Rheinischen Pilze. Jahrbücher des Nassauischen Vereins für Naturkunde 23-24: 1-459.

Hall TA. 1999. BioEdit: a user-friendly biological sequence alignment editor and analysis, program for Windows 95/98/NT. Nucleic Acids Symposium Series 41: 95-98.

Jaklitsch WM. 2009. European species of Hypocrea - Part I. Studies in Mycology 63: 1-91.

Jaklitsch WM, Baral HO, Lücking R, et al. 2016b. Syllabus of plant families - A. Engler's Syllabus der Pflanzenfamilien Part 1/2: Ascomycota. 13th edn. Borntraeger, Berlin.

Jaklitsch WM, Barr ME. 1997. Dictyoporthe bipapillata - a new combination and a key to the species of Dictyoporthe. Österreichische Zeitschrift für Pilzkunde 6: 45-49.

Jaklitsch WM, Checa J, Blanco MN, et al. 2018. A preliminary account of the Cucurbitariaceae. Studies in Mycology 90: 71-118.

Jaklitsch WM, Gardiennet A, Voglmayr H. 2016a. Resolution of morphologybased taxonomic delusions: Acrocordiella, Basiseptospora, Blogiascospora, Clypeosphaeria, Hymenopleella, Lepteutypa, Pseudapiospora, Requienella, Seiridium and Strickeria. Persoonia 37: 82-105.

Jaklitsch WM, Komon M, Kubicek CP, et al. 2005. Hypocrea voglmayrii sp. nov. from the Austrian Alps represents a new phylogenetic clade in Hypocrea/Trichoderma. Mycologia 97: 1365-1378

Jaklitsch WM, Olariaga I, VogImayr H. 2016c. Teichospora and the Teichosporaceae. Mycological Progress 15: 31 (1-20).

Jaklitsch WM, Stadler M, Voglmayr H. 2012. Blue pigment in Hypocrea caerulescens sp. nov. and two additional new species in sect. Trichoderma. Mycologia 104: 925-941.

Jaklitsch WM, Voglmayr H. 2014. Persistent hamathecial threads in the Nectriaceae, Hypocreales: Thyronectria revisited and re-instated. Persoonia 33: 182-211.

Jaklitsch WM, Voglmayr H. 2017. Three former taxa of Cucurbitaria and considerations on Petrakia in the Melanommataceae. Sydowia 69: 81-95.

Kauff F, Lutzoni F. 2002. Phylogeny of Gyalectales and Ostropales (Ascomycota, Fungi): among and within order relationships based on nuclear ribosomal RNA small and large subunits. Molecular Phylogenetics and Evolution 25: 138-156.

Kohlmeyer J, Schatz S. 1985. Aigialus gen. nov. (Ascomycetes) with two new marine species from mangroves. Transactions of the British Mycological Society 85: 699-707.

Landvik S, Egger K, Schumacher T. 1997. Towards a subordinal classification of the Pezizales (Ascomycota): phylogenetic analyses of SSU rDNA sequences. Nordic Journal of Botany 17: 403-418.

Liu YL, Whelen S, Hall BD. 1999. Phylogenetic relationships among ascomycetes: evidence from an RNA polymerase II subunit. Molecular Biology and Evolution 16: 1799-1808.

Mirza F. 1968. Taxonomic investigations on the ascomycetous genus $\mathrm{Cu}-$ curbitaria S.F. Gray. Nova Hedwigia 16: 161-213.

Müller K. 2004. PRAP - calculation of Bremer support for large data sets. Molecular Phylogenetics and Evolution 31: 780-782.
O'Donnell K, Cigelnik E. 1997. Two divergent intragenomic rDNA ITS2 types within a monophyletic lineage of the fungus Fusarium are nonorthologous. Molecular Phylogenetics and Evolution 7: 103-116.

Phookamsak R, Hyde KD. 2015. Fenestellaceae. Mycosphere 6: 402-413. Rehner SA, Buckley E. 2005. A Beauveria phylogeny inferred from nuclear ITS and EF1- $\alpha$ sequences: evidence for cryptic diversification and links to Cordyceps teleomorphs. Mycologia 97: 84-98.

Saccardo PA. 1884. Miscellanea Mycologica I (V). Atti dell'Istituto Veneto di Scienze 2 (VI): 5 (1-29)

Silvestro D, Michalak I. 2012. raxmIGUI: a graphical front-end for RAxML. Organisms Diversity \& Evolution 12: 335-337.

Spatafora JW, Sung GH, Johnson D, et al. 2006. A five-gene phylogeny of Pezizomycotina. Mycologia 98: 1018-1028.

Stamatakis E. 2006. RAxML-VI-HPC: maximum likelihood-based phylogenetic analyses with thousands of taxa and mixed models. Bioinformatics 22: $2688-2690$

Swofford DL. 2002. PAUP* 4.0b10: phylogenetic analysis using parsimony (*and other methods). Sinauer Associates, Sunderland, Massachusetts.

Thiers B. 2018. Index Herbariorum: A global directory of public herbaria and associated staff. New York Botanical Garden's Virtual Herbarium. http:// sweetgum.nybg.org/ih/.

Tulasne LR, Tulasne C. 1863. Selecta Fungorum Carpologia 2. Paris.

Valenzuela-Lopez N, Cano-Lira JF, Guarro J, et al. 2018. Coelomycetous Dothideomycetes with emphasis on the families Cucurbitariaceae and Didymellaceae. Studies in Mycology 90: 1-69.

Vilgalys R, Hester M. 1990. Rapid genetic identification and mapping of enzymatically amplified ribosomal DNA from several Cryptococcus species. Journal of Bacteriology 172: 4238-4246.

Voglmayr H, Akulov OY, Jaklitsch WM. 2016a. Reassessment of Allantonectria, phylogenetic position of Thyronectroidea, and Thyronectria caraganae sp. nov. Mycological Progress 15: 921.

Voglmayr H, Castlebury LA, Jaklitsch WM. 2017. Juglanconis gen. nov. on Juglandaceae, and the new family Juglanconidaceae (Diaporthales). Persoonia 38: 136-155.

Voglmayr H, Gardiennet A, Jaklitsch WM. 2016b. Asterodiscus and Stigmatodiscus, two new apothecial dothideomycete genera and the new order Stigmatodiscales. Fungal Diversity 80: 271-284.

Voglmayr H, Jaklitsch WM. 2008. Prosthecium species with Stegonsporium anamorphs on Acer. Mycological Research 112: 885-905.

VogImayr H, Jaklitsch WM. 2011. Molecular data reveal high host specificity in the phylogenetically isolated genus Massaria (Ascomycota, Massariaceae). Fungal Diversity 46: 133-170.

Voglmayr H, Jaklitsch WM. 2014. Stilbosporaceae resurrected: generic reclassification and speciation. Persoonia 33: 61-82.

Voglmayr H, Jaklitsch WM. 2017. Corynespora, Exosporium and Helminthosporium revisited - new species and generic reclassification. Studies in Mycology 87: 43-76

Voglmayr H, Rossman AY, Castlebury LA, et al. 2012. Multigene phylogeny and taxonomy of the genus Melanconiella (Diaporthales). Fungal Diversity 57: 1-44.

Von NiessI G 1872. Beiträge zur Kenntniss der Pilze. Verhandlungen des naturforschenden Vereines in Brünn 10: 153-217, pl. 3-7.

Wanasinghe DN, Hyde KD, Jeewon R, et al. 2017a. Phylogenetic revision of Camarosporium (Pleosporineae, Dothideomycetes) and allied genera. Studies in Mycology 87: 207-256.

Wanasinghe DN, Phookamsak R, Jeewon R, et al. 2017b. A family level rDNA based phylogeny of Cucurbitariaceae and Fenestellaceae with descriptions of new Fenestella species and Neocucurbitaria gen. nov. Mycosphere 8: 397-414.

Werle E, Schneider C, Renner M, et al. 1994. Convenient single-step, one tube purification of PCR products for direct sequencing. Nucleic Acids Research 22: 4354-4355.

White TJ, Bruns T, Lee S, et al. 1990. Amplification and direct sequencing of fungal ribosomal RNA genes for phylogenetics. In: Innis MA, Gelfand $\mathrm{DH}$, Sninsky JJ, et al. (eds), PCR protocols: A guide to methods and applications: 315-322. Academic Press, San Diego. 